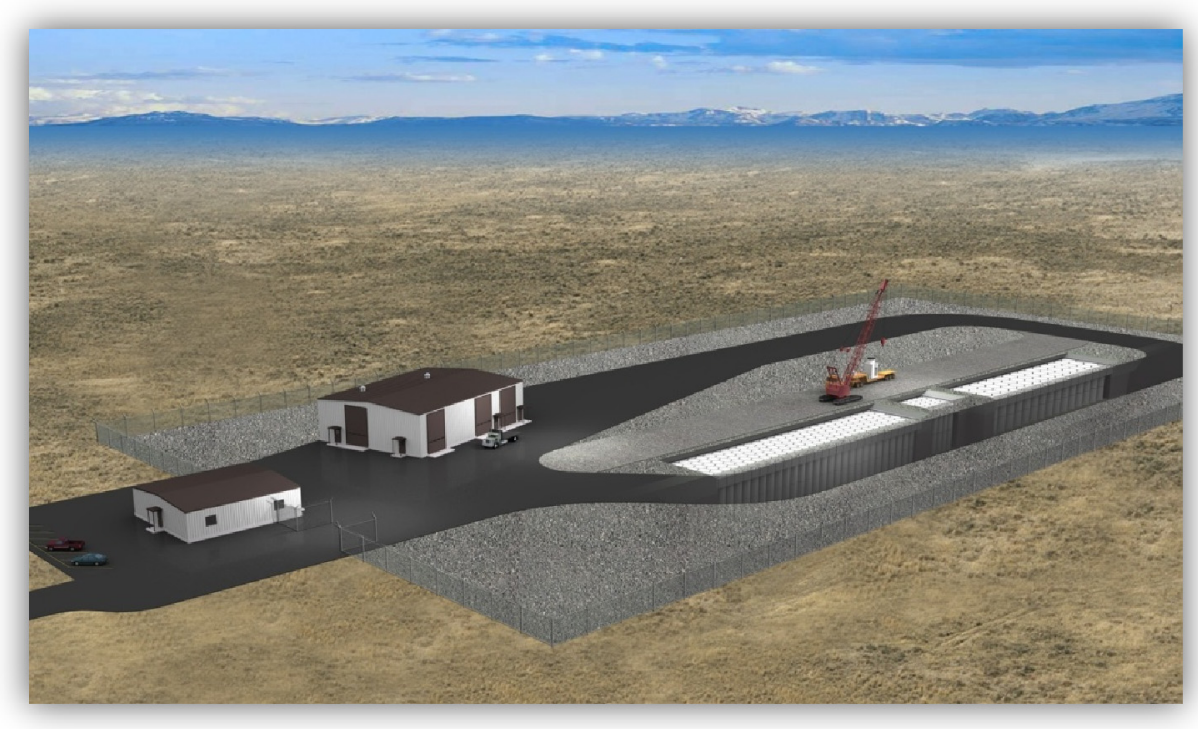

\title{
Conceptual Design Report for the Remote-Handled Low-Level Waste Disposal Project
}

March 2011

INL is a U.S. Department of Energy National Laboratory operated by Battelle Energy Alliance 



\title{
Conceptual Design Report for the Remote-Handled Low-Level Waste Disposal Project
}

March 2011

Idaho National Laboratory

Idaho Falls, Idaho 83415

\author{
Prepared for the \\ U.S. Department of Energy \\ Office of Nuclear Energy \\ Under DOE Idaho Operations Office \\ Contract DE-AC07-05ID14517
}




\section{NOTE:}

This document addresses the conceptual design parameters associated with a proposed onsite remote-handled low-level waste disposal facility. A new onsite facility has been identified as an alternative for providing continued remote-handled low-level waste disposal capability in support of ongoing Department of Energy missions at the Idaho site. However, a decision has not been made by the Department of Energy to develop a new onsite disposal facility. The decision, following all required analyses and evaluation of the impacts of all viable alternatives, will be made in accordance with the National Environmental Policy Act of 1969. Use of words indicating requirements or specifying intention, such as "shall" or "will," are used for the convenience of discussion or to indicate requirements or activities that are conditioned on a decision to develop a new onsite disposal facility. Such usage should not be construed to mean that a final selection of an alternative has been made. 


\begin{abstract}
This conceptual design report addresses development of replacement remote-handled low-level waste disposal capability for the Idaho National Laboratory. Current disposal capability at the Radioactive Waste Management Complex is planned until the facility is full or until it must be closed in preparation for final remediation (approximately at the end of Fiscal Year 2017). This conceptual design report includes key project assumptions; design options considered in development of the proposed onsite disposal facility (the highest ranked alternative for providing continued uninterrupted remote-handled low-level waste disposal capability); process and facility descriptions; safety and environmental requirements that would apply to the proposed facility; and the proposed cost and schedule for funding, design, construction, and operation of the proposed onsite disposal facility.
\end{abstract}




\section{EXECUTIVE SUMMARY}

This conceptual design report provides documentation of plans to design, construct, and operate a proposed facility for disposal of remote-handled low-level waste (LLW) at the Idaho National Laboratory. The conceptual design report was prepared in accordance with Department of Energy Order 413.3B, "Program and Project Management for Acquisition of Capital Assets." This report, coupled with other Critical Decision (CD)-1 documentation, provides information needed by the Department of Energy to make a determination to proceed with the project execution phase and establish a preliminary baseline for the proposed project. The following sections are included in the conceptual design report:

Section 1 Provides an introduction and overview of the project. It includes a description of the mission need for the Remote-Handled LLW Disposal Project; alternatives considered in developing the mission need; and identification of the highest ranked alternative to establish uninterrupted remote-handled LLW disposal capability for the Idaho National Laboratory.

Section 2 Provides background information on the project. It includes a description of project assumptions and options considered in the design; a description of the systems engineering, value management, and risk management approaches; a summary of the strategy for acquiring and funding the project; identification of anticipated staffing needs; and listing of applicable codes, standards, and regulations.

Section 3 Includes the process description for proposed facility operations.

Section $4 \quad$ Summarizes the proposed conceptual facility design.

Sections 5 and 6 Provides the proposed costs and schedule for the proposed project.

Section 7 Presents information on nuclear safety, including a discussion of required safety documentation, initial assessments of the hazard classification and seismic design category for the proposed facility, and a discussion of emergency preparedness.

Section $8 \quad$ Addresses safeguards and security measures applicable to the proposed remote-handled LLW disposal facility.

Section 9 Provides a list of the applicable environmental, safety, and health requirements for the proposed facility.

Section 10 Summarizes the risk management plan specifically developed for the project.

Section 11 Addresses requirements for readiness reviews required for the proposed facility prior to operational turnover. 
Section 12 Identifies the requirements and approach to quality assurance throughout the project.

Section $13 \quad$ Provides references.

The Remote-Handled LLW Disposal Project addresses an anticipated shortfall in remote-handled LLW disposal capability following cessation of operations at the existing facility, which will continue until it is full or until it must be closed in preparation for final remediation of the Subsurface Disposal Area (approximately at the end of Fiscal Year 2017). Development of the proposed onsite disposal facility, the highest ranked alternative, would provide necessary remote-handled LLW disposal capability and would ensure continuity of operations that generate remote-handled LLW. 


\section{CONTENTS}

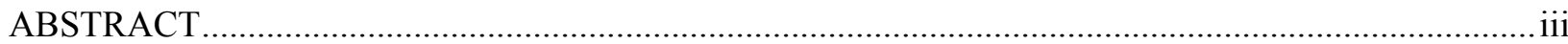

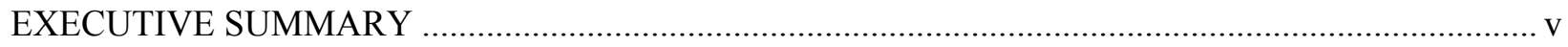

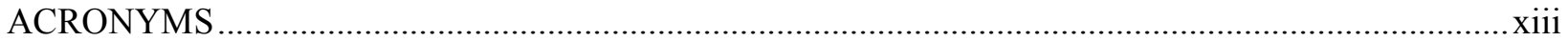

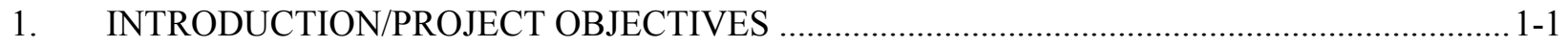

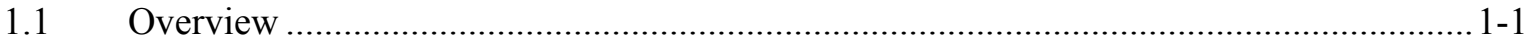

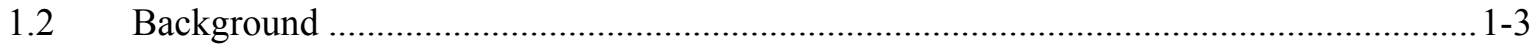

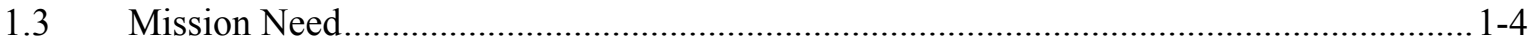

1.3.1 Summary of Alternatives for Continued Idaho National Laboratory

Remote-Handled Low-Level Waste Disposal Capability ............................... 1-4

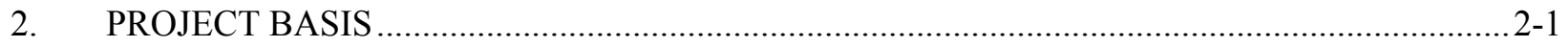

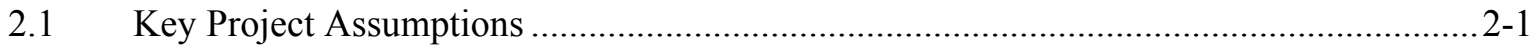

2.2 Conceptual Design Requirements Development ......................................................2-2

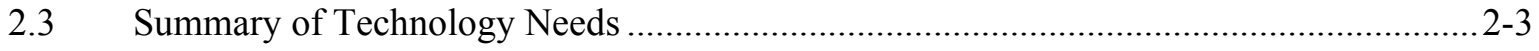

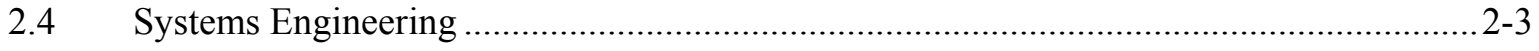

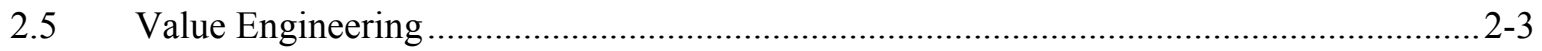

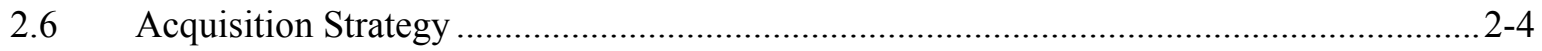

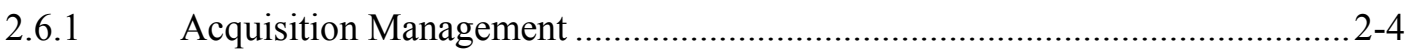

2.6.2 Business and Acquisition Approach …........................................................... 2-4

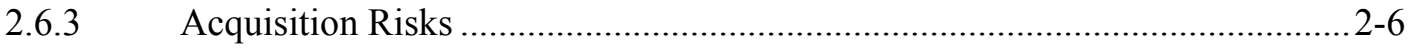

2.6.4 Interfaces and Integration Requirements.............................................. 2-6

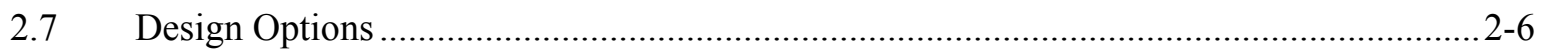

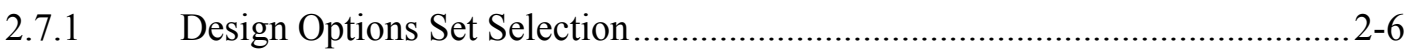

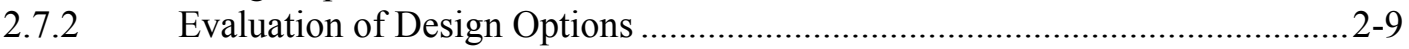

2.7.3 Conclusions of Design Options Evaluation................................................2-12

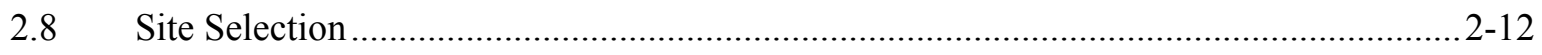

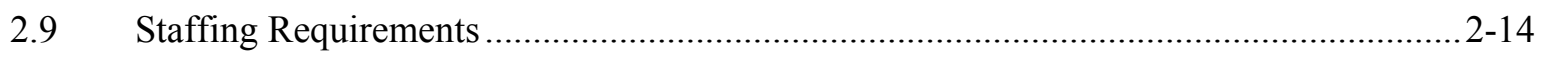

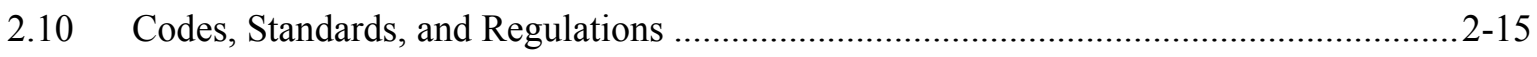




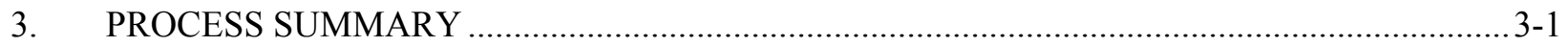

Process Description ............................................................................................ $3-2$

3.2 Anticipated Waste Streams................................................................................. $3-5$

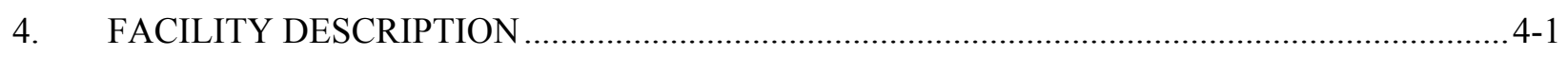

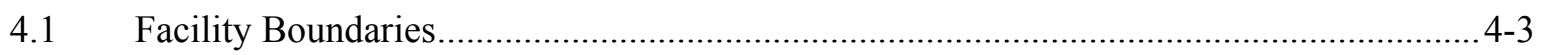

4.2 Coordination of Activities between Facilities/Organizations.......................................... 4-3

4.3 Facility Conceptual Design Assumptions............................................................. 4-3

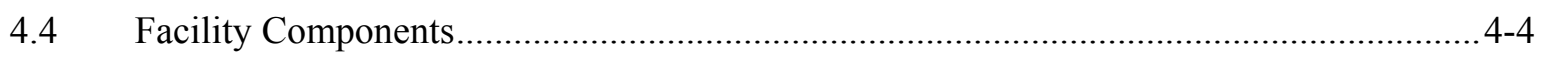

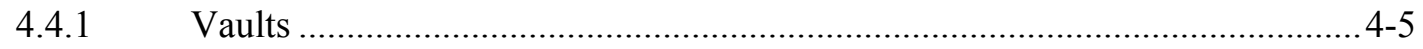

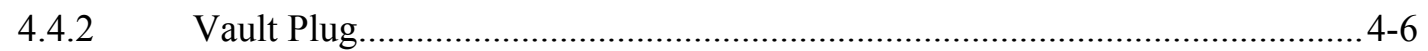

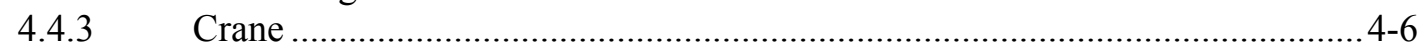

4.4.4 Cask-to-Vault Adapting Structure .......................................................... 4-7

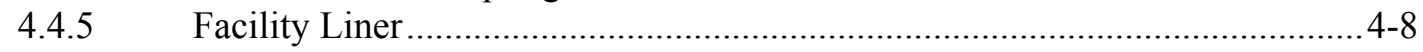

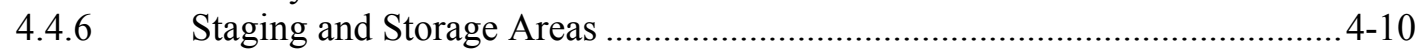

4.4.7 Administration and Other Supporting Infrastructure .................................4-10

4.4.8 Final Closure Cover ....................................................................... $4-11$

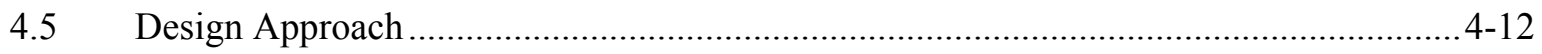

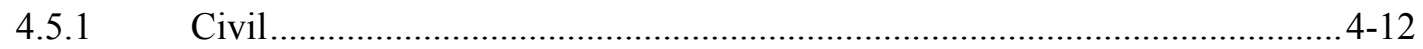

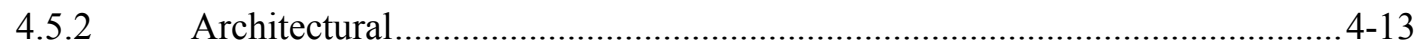

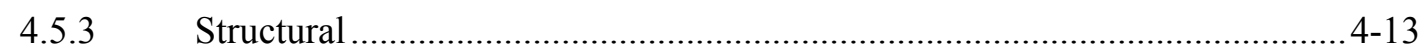

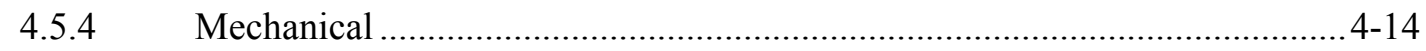

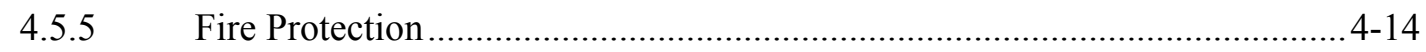

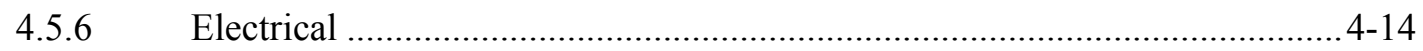

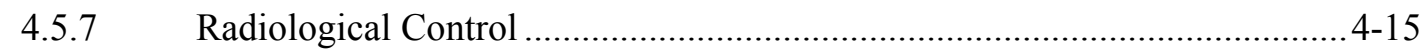

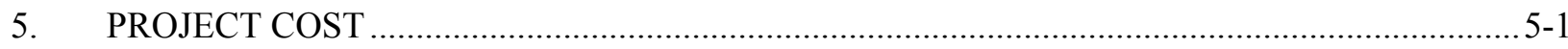

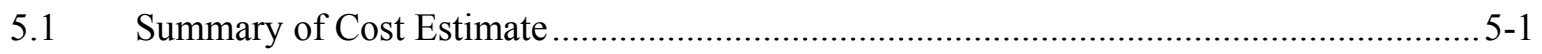

5.2 Total Project Cost Range ....................................................................................... $5-1$

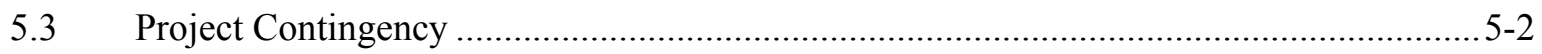

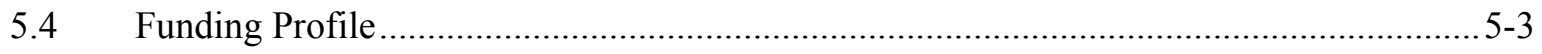

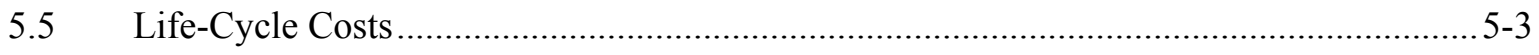

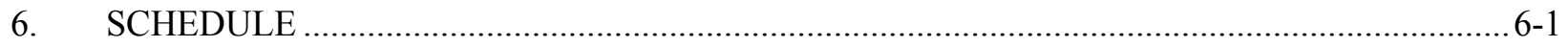

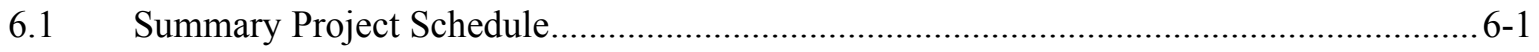

6.1.1 Project Planning and Execution ................................................................ 6-1 


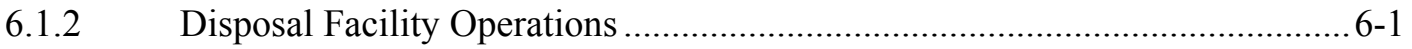

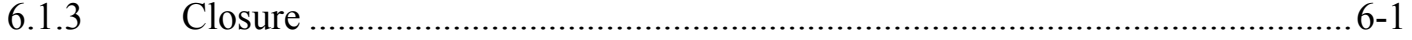

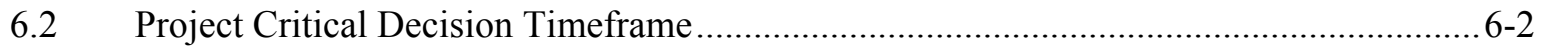

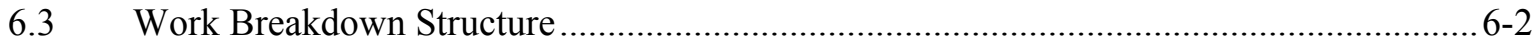

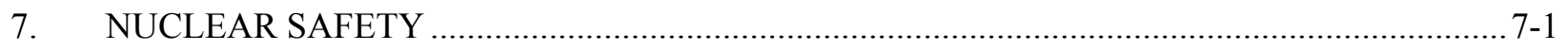

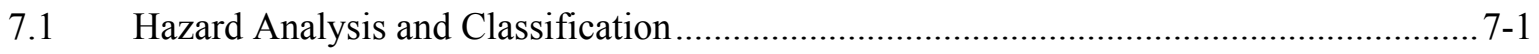

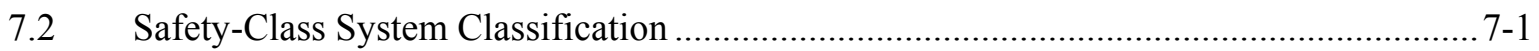

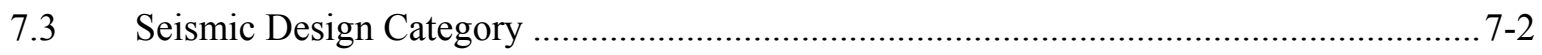

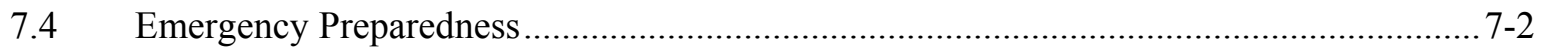

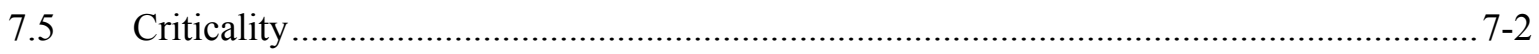

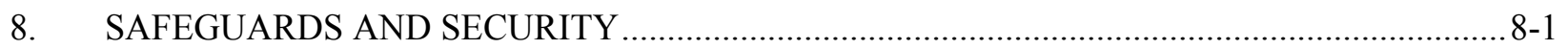

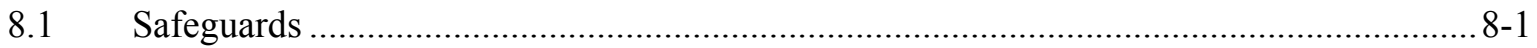

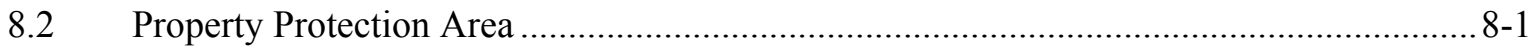

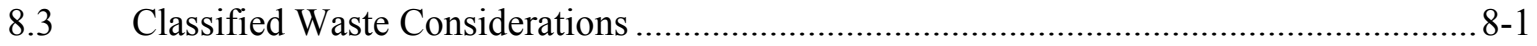

8.4 Additional Security Considerations ....................................................................... 8-1

9. ENVIRONMENTAL, SAFETY, AND HEALTH REQUIREMENTS ….................................. 9-1

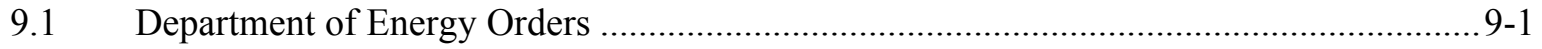

9.1.1 DOE Order 435.1, Radioactive Waste Management …..................................9-1

9.1.2 DOE Order 450.1, Environmental Protection Program ..................................9-2

9.1.3 DOE Order 420.1B, Facility Safety ........................................................... 9-3

9.1.4 DOE Order 5400.5, Radiation Protection of the Public and the Environment.9-3

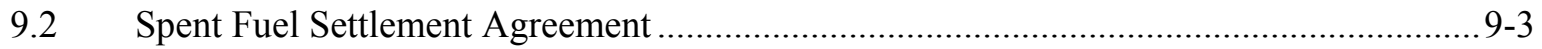

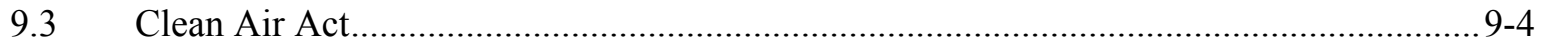

9.4 Comprehensive Environmental Response, Compensation, and Liability Act...................9-4

9.5 Federal Facilities Agreement and Consent Order.................................................. 9-5

$9.6 \quad$ National Environmental Policy Act......................................................................... 9-5

9.7 Department of Energy/Tribal Agreement in Principle ............................................... 9-6

9.8 Environmental Oversight and Monitoring Agreement .............................................. 9-6 
9.9 Idaho National Laboratory Labor Terms and Conditions............................................. 9-6

9.10 Safe Drinking Water Act/Idaho Regulations for Public Drinking Water Systems............. 9-6

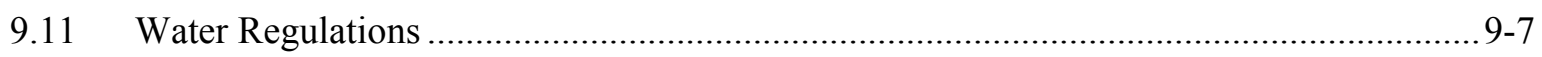

9.12 Hazardous Waste Management Act/Resource Conservation and Recovery Act and Related

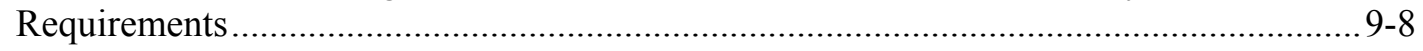

9.13 Pollution Prevention and Waste Minimization............................................................ 9-8

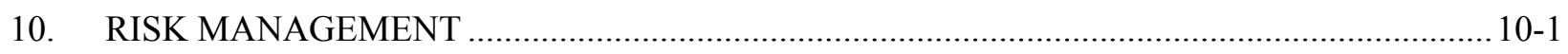

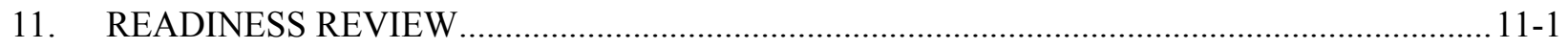

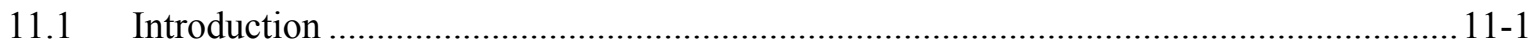

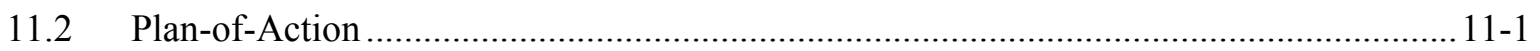

11.3 Implementation Plan......................................................................................... 11-1

11.4 Contractor Operational Readiness Review ................................................................ 11-2

11.5 Department of Energy Operational Readiness Review .......................................... 11-2

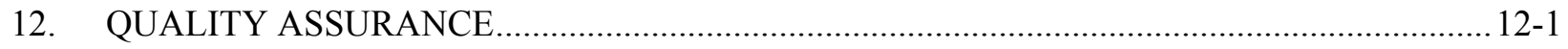

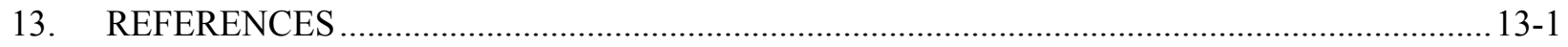

\section{APPENDIXES}

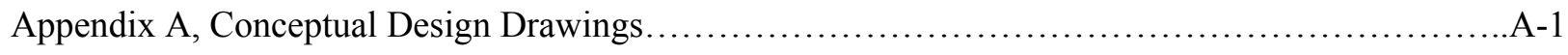

Appendix B, Sustainability Design Report...............................................

Appendix C, Engineering Design Review..................................................

\section{FIGURES}

1-1. Locations of the Advanced Test Reactor Complex, Materials and Fuels Complex, and Naval Reactors Facility at the Idaho National Laboratory

1-2. Projection of anticipated remote-handled low-level waste generation through Fiscal Year 2037

2-1. Remote-Handled Low-Level Waste Disposal Project timeline

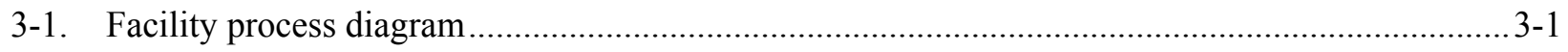

3-2. A 55-ton scrap cask used for transporting waste to the disposal facility ....................................3-3 
3-3. Waste container used inside the 55-ton scrap cask.

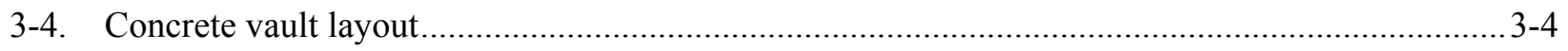

4-1. Conceptual layout for the proposed Remote-Handled Low-Level Waste Disposal Facility...........4-1

4-2. Proposed Remote-Handled Low-Level Waste Facility operational configuration......................... 4-2

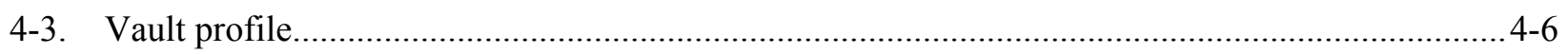

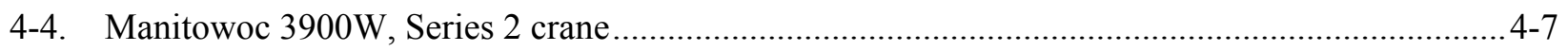

4-5. Vault disposal process with the cask-to-vault adapting structure components ............................ 4-8

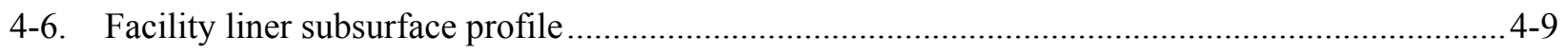

4-7. A 55-ton cask transport vehicle ….................................................................................. 4-11

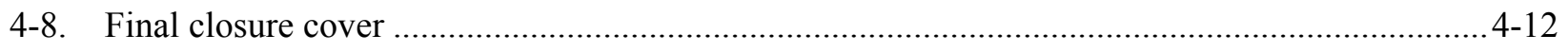

5-1. Target funding profile for the Remote-Handled Low-Level Waste Disposal Project .................... 5-4

5-2. Idaho National Laboratory Remote-Handled Low-Level Waste Disposal Facility

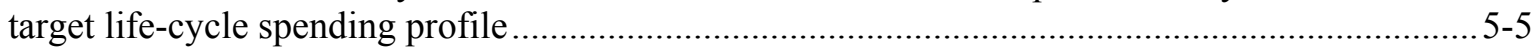

\section{TABLES}

2-1. Risk analysis for the Remote-Handled Low-Level Waste Disposal Project ................................2-7

3-1. Remote-handled low-level waste stream descriptions.......................................................... 3-5

3-2. Estimated number of remote-handled low-level waste containers that would require disposal from Fiscal Year 2018 through Fiscal Year 2037 (20-year operation) ........................... 3-6

4-1. Remote-Handled Low-Level Waste Disposal Facility anticipated electrical load summary ........ 4-15

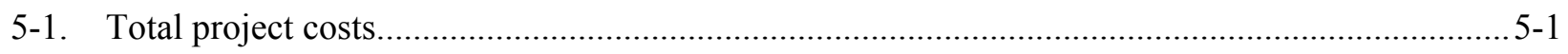

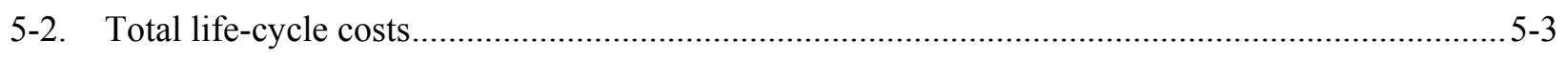

6-1. Critical decision milestones for the Remote-Handled Low-Level Waste Disposal Project ............ 6-2

12-1. American Society of Mechanical Engineers NQA-1-2000 criteria applicable to the proposed Remote-Handled Low-Level Waste Disposal Facility 


\section{ACRONYMS}

ATR Advanced Test Reactor

CD critical decision

CERCLA Comprehensive Environmental Response, Compensation, and Liability Act

CFR Code of Federal Regulations

CVAS cask-to-vault adapting structure

DOE Department of Energy

DOE-ID Department of Energy, Idaho Operations Office

EPA Environmental Protection Agency

FY fiscal year

IBC International Building Code

IDAPA Idaho Administrative Procedures Act

INL Idaho National Laboratory

LEED Leadership in Energy and Environmental Design

LLW low-level waste

LWP laboratory-wide procedure

MFC Materials and Fuels Complex

NEPA National Environmental Policy Act

NRF Naval Reactors Facility

OPC other project costs

ORR operational readiness review

QAP quality assurance program

RCRA Resource Conservation and Recovery Act

RWMC Radioactive Waste Management Complex

SDA Subsurface Disposal Area

TEC total estimated cost 
TFR technical and functional requirements

TPC total project cost

WBS work breakdown structure 


\section{Conceptual Design Report for the Remote-Handled Low-Level Waste Disposal Project}

\section{INTRODUCTION/PROJECT OBJECTIVES}

\subsection{Overview}

The Idaho National Laboratory (INL), an $890-\mathrm{mi}^{2}\left(2,305-\mathrm{km}^{2}\right)$ section of desert in southeast Idaho, was established in 1949 as the National Reactor Testing Station. Initially, the missions at INL were development of civilian and defense nuclear reactor technologies and management of spent nuclear fuel. Today, INL is a multipurpose national laboratory delivering specialized science and engineering solutions for the U.S. Department of Energy (DOE). Sponsorship of INL was formally transferred to the DOE Office of Nuclear Energy by Secretary of Energy Spencer Abraham in July 2002. The move to the Office of Nuclear Energy and designation, along with Argonne National Laboratory, as the DOE lead nuclear energy laboratory for reactor technology, supports the nation's expanding nuclear energy initiatives, placing INL at the center of work to do the following:

- $\quad$ Develop advanced Generation IV nuclear energy systems

- Develop nuclear energy/hydrogen coproduction technology

- Develop advanced nuclear energy fuel cycle technologies

- $\quad$ Provide national security answers to national infrastructure needs.

INL facilities carrying out the Office of Nuclear Energy mission are concentrated in two main complexes at the Idaho site, the Advanced Test Reactor (ATR) Complex and the Materials and Fuels Complex (MFC). In addition, INL hosts the National Nuclear Security Agency's Naval Reactors Facility (NRF). NRF supports the U.S. Navy's nuclear-powered fleet through research and development of materials and equipment, as assigned by the Office of the Deputy Administrator for Naval Reactors. Figure 1-1 presents a map of the INL highlighting the locations of the ATR, MFC, and NRF.

Remote-handled low-level waste (LLW) activated metal waste streams are generated from operations at INL's NRF and ATR Complex. Activated metals also may be generated from operations and from segregation and treatment (as necessary) of remote-handled scrap and waste currently stored at MFC. Additionally, remote-handled LLW ion-exchange resin waste streams are generated from operations at NRF and ATR. Disposal of remote-handled LLW in the disposal vaults of the existing INL waste disposal facility is planned through the end of Fiscal Year (FY) 2017. Continued remote-handled LLW disposal capability is critical to continuing DOE Office of Nuclear Energy and Office of Naval Reactors missions conducted at INL.

This document summarizes alternatives presented in the project mission need statement and the process used to identify the highest ranked alternative (i.e., development of an onsite remote-handled LLW disposal facility) to maintain continued, uninterrupted INL remote-handled LLW disposal capability and presents the conceptual design for construction of such a facility at INL. The proposed disposal facility would be capable of receiving remote-handled LLW beginning in FY 2018 and continuing through at least the end of FY 2037 (Figure 1-2). The facility initially would include approximately 250 precast concrete vaults. The vaults would be configured to receive the remote-handled LLW in waste containers (i.e., cask liners) transported in shielded shipping casks from INL generators. 


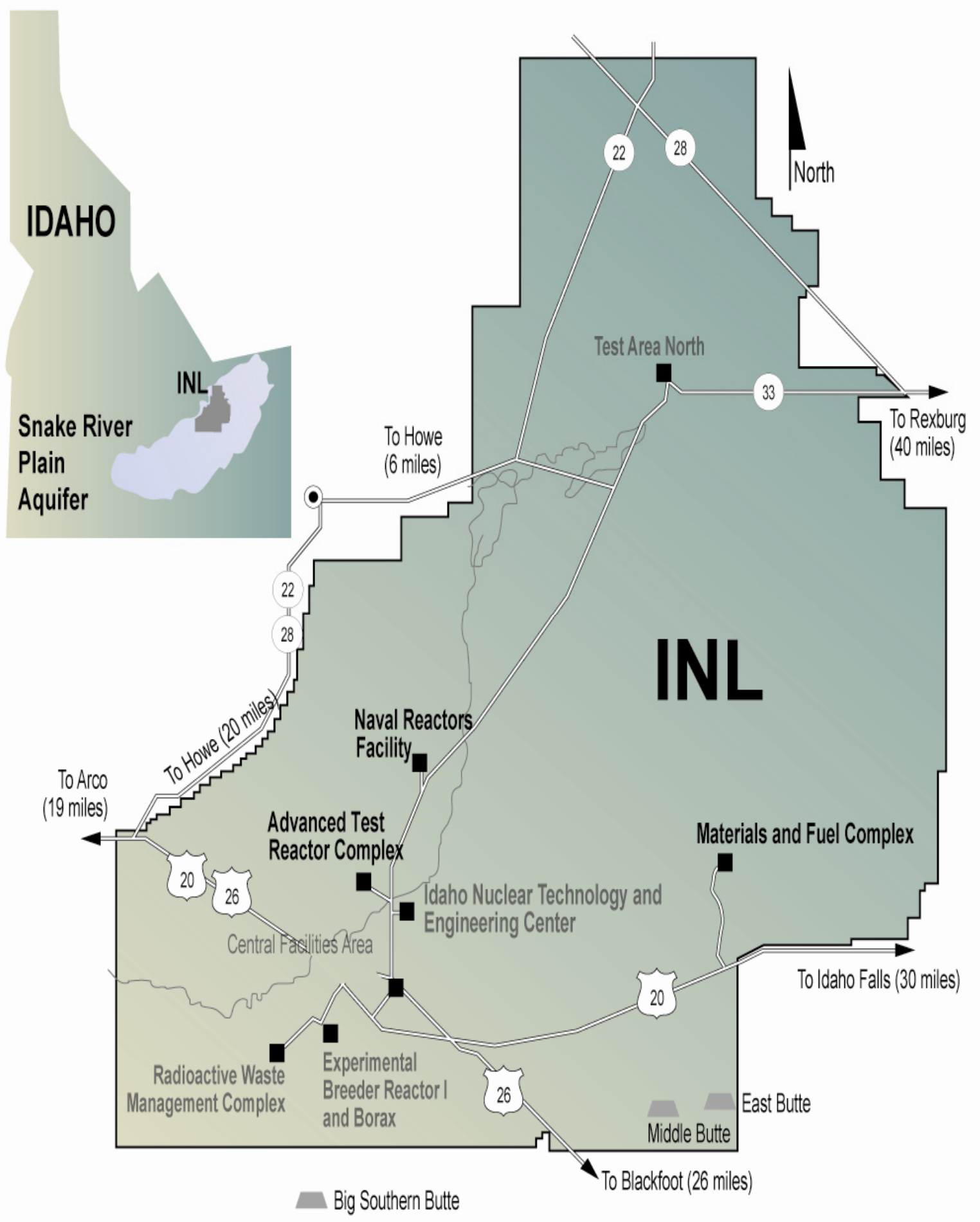

Figure 1-1. Locations of the Advanced Test Reactor Complex, Materials and Fuels Complex, and Naval Reactors Facility at the Idaho National Laboratory. 


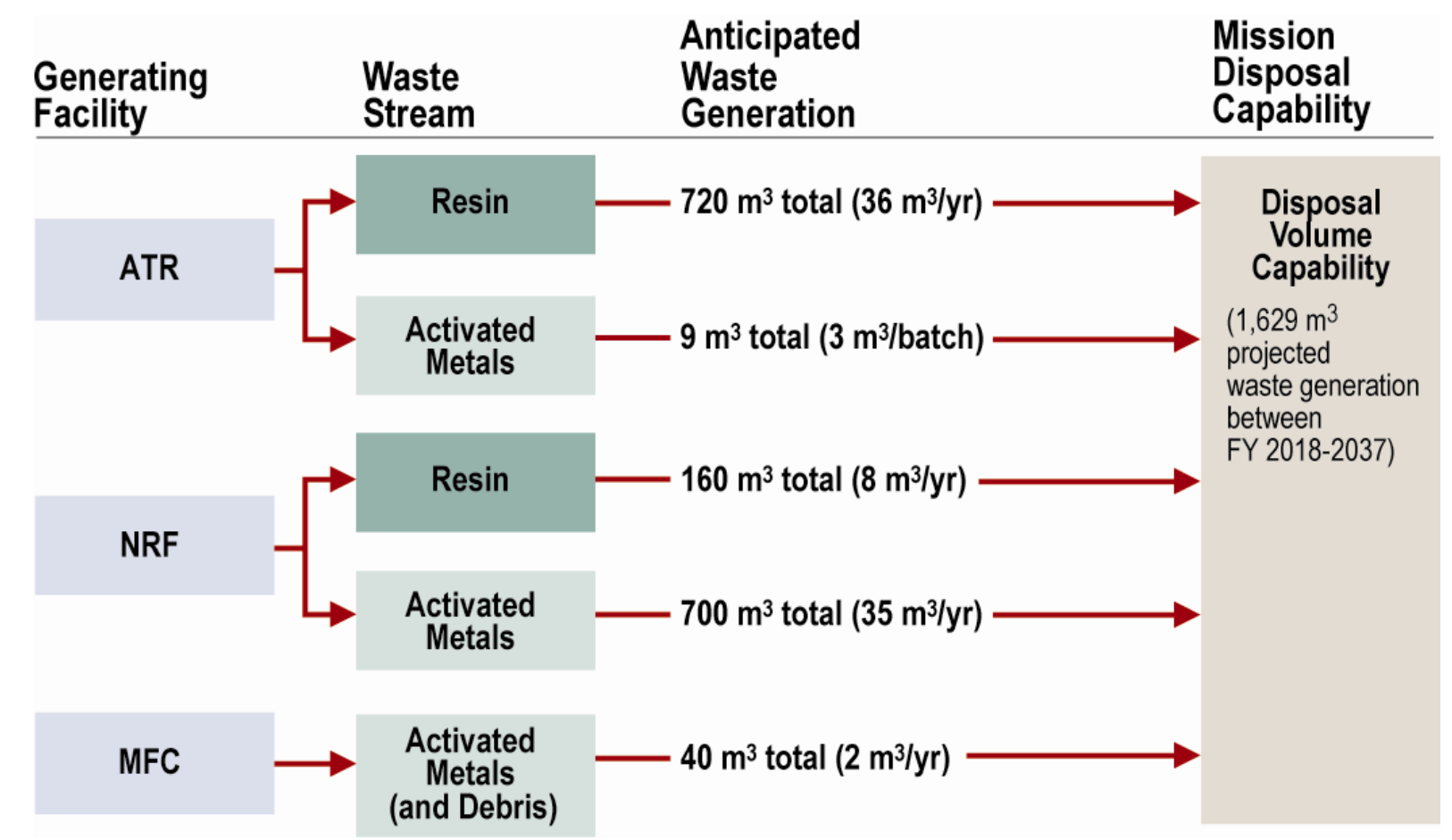

Figure 1-2. Projection of anticipated remote-handled low-level waste generation through Fiscal Year 2037.

\subsection{Background}

Under the Atomic Energy Act of 1954 (42 USC § 2011 et seq.), as amended, DOE is responsible for waste it generates. DOE Manual 435.1-1, "Radioactive Waste Management," provides DOE's policy for management of radioactive waste, including remote-handled LLW:

DOE radioactive waste shall be treated, stored, and in the case of low-level waste, disposed of at the site where the waste is generated, if practical; or at another DOE facility. If DOE capabilities are not practical or cost effective, exemptions may be approved to allow use of non-DOE facilities for the storage, treatment, or disposal of DOE radioactive waste.

Until September 30, 2008, INL disposed of its remote-handled LLW in a disposal facility located in the Subsurface Disposal Area (SDA) at the Radioactive Waste Complex (RWMC). Continued disposal of remote-handled LLW in the SDA concrete vaults is planned until the facility is full or until it must be closed in preparation for final remediation (approximately at the end of FY 2017). Disposal of ATR remote-handled LLW ion-exchange resins in the open pit of the SDA ceased at the end of FY 2008 following closure of the open pit. This waste is currently shipped offsite for disposal. The SDA is being remediated under a Federal Facilities Agreement/Consent Order (DOE-ID 1991) between DOE, the State of Idaho, and the U.S. Environmental Protection Agency (EPA) that guides Comprehensive Environmental Response, Compensation, and Liability Act (CERCLA) (42 USC $\S 9601$ et seq.) response actions at INL. 


\subsection{Mission Need}

The continuing nuclear mission at INL, associated ongoing and planned operations, and Naval spent fuel activities at NRF require continued capability to appropriately dispose of remote-handled LLW. However, with the closure of RWMC, INL will no longer have an onsite disposal capability for remote-handled LLW. The Remote-Handled LLW Disposal Project will establish continued, uninterrupted, remote-handled LLW disposal capability. Replacement remote-handled LLW disposal capability is required by October 1, 2017.

Providing continued disposal capability for remote-handled LLW supports the Office of Nuclear Energy's mission "to lead the DOE investment in the development and exploration of advanced nuclear science and technology." Without established, viable remote-handled LLW disposal capability, ongoing and future Office of Nuclear Energy programs at INL would be adversely impacted as remote-handled LLW disposal options would need to be considered on a program-by-program basis, resulting in increased costs and schedule. The lack of remote-handled LLW disposal capability also may impede DOE's ability to initiate new programs at INL.

Remote-handled LLW disposal capability also is critical to meeting National Nuclear Security Agency's mission to "provide the United States Navy with safe, militarily effective nuclear propulsion plants and to ensure the safe and reliable operation of those plants." All spent nuclear fuel from the Navy's nuclear-powered fleet is sent to NRF for examination, processing, dry storage, and eventual shipment to a permanent geologic repository. A reliable disposal path for remote-handled LLW generated during spent nuclear fuel handling and packaging operations is essential to NRF's continued receipt and processing of Navy spent fuel to support the Naval Nuclear Propulsion Program and national security.

From waste generation projections presented in Figure 1-2, INL must have the capability to dispose of approximately $84 \mathrm{~m}^{3} /$ year of remote-handled LLW with radiation exposure levels up to 30,000 R/hour, commencing by the end of FY 2017.

\subsubsection{Summary of Alternatives for Continued Idaho National Laboratory Remote-Handled Low-Level Waste Disposal Capability}

As identified in the mission need statement for the project (DOE-ID 2009) and further described in the alternatives analysis (INL 2011), multiple alternatives have been identified for continuing INL remote-handled LLW disposal activities, including the following:

- $\quad$ Continued disposal at RWMC

- $\quad$ Disposal at Idaho CERCLA Disposal Facility

- Interim storage

- $\quad$ Storage for decay

- $\quad$ Design, construct, and operate a new onsite remote-handled LLW disposal facility

- $\quad$ Dispose of all remote-handled LLW offsite at the Nevada National Security Site (formerly known as the Nevada Test Site)

- $\quad$ Privatization of INL remote-handled LLW disposal

- $\quad$ No action. 


\subsubsection{Recommended Alternative}

An alternatives analysis report (INL 2011) for the remote-handled LLW project was prepared to evaluate the alternatives identified in the mission need statement (DOE-ID 2009). Each alternative was assessed for its viability in providing continued, uninterrupted remote-handled LLW disposal capability. From this assessment, two potentially viable alternatives were identified (i.e., design, construct, and operate a new onsite remote-handled LLW disposal facility [onsite disposal] and dispose of all remote-handled LLW offsite [offsite disposal]). Each alternative was ranked based on its ability to meet criteria addressing cost, project risk, and complexity. The highest ranked alternative identified through the alternatives analysis is the development of a new onsite remote-handled LLW disposal facility. Of the potentially viable alternatives considered, onsite disposal of INL and tenant-generated remote-handled LLW has the lowest life-cycle cost to DOE and provides the lowest risk. Costs are reduced through avoidance of costs to develop transportation infrastructure and to conduct offsite shipments. Project risks, such as uncertainty of availability of offsite facilities, are eliminated using onsite disposal. Reliance on other activities or programs in order to achieve disposal also is minimized, reducing disposal complexity.

Offsite disposal has a higher life-cycle cost due to the number of offsite shipments that would be required and is complicated by transportation issues associated with transporting highly radioactive waste in commerce and by the infrastructure and processing changes at the generating facilities, specifically $\mathrm{NRF}$, that would be required to support offsite disposal.

Through establishment of the proposed onsite remote-handled LLW disposal facility, risks associated with transport of highly radioactive waste would be reduced, life-cycle waste management costs would be minimized, and the necessary waste management infrastructure to support ongoing and future Office of Nuclear Energy and Office of Naval Reactors programs would be maintained. Development of the proposed onsite disposal facility would yield the following benefits:

- $\quad$ Provide for uninterrupted remote-handled LLW disposal capability, thereby minimizing potential impacts on INL and NRF operations

- Allow for continued processing of Navy fuels at NRF, enabling compliance with the Idaho Settlement Agreement commitments

- $\quad$ Eliminate the need for significant capital investment in major infrastructure modifications to support offsite disposal of remote-handled LLW, including, but not limited to, acquisition of a Nuclear Regulatory Commission-licensed, Department of Transportation-compliant cask system(s) for offsite transportation; facility infrastructure modifications to support the new transport system(s); and expansion of onsite interim storage capabilities to address offsite shipment campaigns

- $\quad$ Provide for remote-handled LLW management and disposal consistent with DOE Order 435.1, which states:

DOE radioactive waste shall be treated, stored, and in the case of low-level waste, disposed of at the site where the waste is generated, if practical

- $\quad$ Decrease risks associated with offsite transport of waste

- Maintain DOE control of remote-handled LLW disposal and decrease the potential for diversion or sabotage of waste 
- $\quad$ Provide a consistent, sitewide waste management system, reducing required coordination among multiple programs to identify and implement cost-effective waste management options

- $\quad$ Reduce dependence on the cooperation of third parties, such as disposal site operators, states other than Idaho (shipment and disposal), and other federal agencies (e.g., Nuclear Regulatory

Commission for cask certification) to the absolute minimum

- $\quad$ Provide the most cost-effective approach for management of remote-handled LLW, minimizing life-cycle costs to DOE.

The remainder of this conceptual design report focuses on the requirements and design of a proposed onsite remote-handled LLW disposal facility. A formal DOE decision as how to proceed with the project will be made in accordance with the requirements of National Environmental Policy Act (NEPA) (42 USC $\$ 4321$ et seq.). Viable locations for the proposed onsite disposal facility have been identified as part of a siting study (INL 2010c). The site with the highest score will be included as part of the NEPA process should DOE make a decision to build the proposed onsite disposal facility. 


\section{PROJECT BASIS}

This section provides key project assumptions, describes the design process and related activities, and describes anticipated staffing requirements associated with development of the proposed onsite remote-handled LLW disposal facility, the highest ranked alternative for meeting the project mission need.

\subsection{Key Project Assumptions}

The following assumptions are used in the conceptual design for the proposed onsite remote-handled LLW disposal facility:

1. The facility would be government-owned and contractor-operated. DOE would provide oversight of the siting, design, construction, and operation of the facility.

2. Project schedule and cost estimates are based on identifying funding levels that would support uninterrupted project staffing and procurement through design, construction, and startup.

3. The facility would be designed with a design life of 50 years; however, the facility initially would be sized for the volume of waste expected to be disposed of over a 20-year period beginning in FY 2018 and continuing through FY 2037.

4. Waste volumes used for design purposes of initial construction are as shown in Figure 1-2.

5. Waste volumes for NRF are based on current plans using the existing process facilities. If the proposed recapitalization project to replace the aging NRF Expended Core Facility is implemented, then the NRF waste generation rates may increase to accommodate additional fuel material processing.

6. The facility would be designed to accept waste with a contact exposure rate up to $30,000 \mathrm{R} /$ hour

7. The conceptual design is based on the existing 55-ton cask and associated systems currently used by NRF.

8. Commercially available casks would be procured by the project and used for shipments of activated metal waste generated from ATR and MFC (for waste generated from potential new missions and from processing of remote-handled waste currently stored at the Radioactive Scrap and Waste Facility). The project would define the transport system specifications to ensure that the cask produced fully complies with all quality and safety standards for the transportation of waste onsite and has undergone all appropriate testing. Through a competitive bid process, a contract would be awarded to a commercial cask supplier who has the design experience, is experienced with the Nuclear Regulatory Commission safety and quality requirements, and has contracts with reputable fabrication vendors.

9. It is assumed that the activated metals waste containers used for disposal would have a cylindrical configuration with a 3-ft $(1-\mathrm{m})$ diameter and 9.3-ft $(2.8-\mathrm{m})$ high maximum dimension that would fit within a commercially available shipping cask(s). 
10. Vaults used for disposal of ATR and MFC-generated, activated metals waste would be sized to accept containers compatible with a commercially available cask system. Typical cask and container handling equipment (i.e., hoisting and rigging components and a shielding bell) would be procured as part of this project. The actual containers used for packaging the remote-handled LLW for transport using a commercially available cask would be selected (or designed) and procured by the individual operating/generating facilities. Any ancillary equipment (e.g., new cask transfer and handling equipment) specifically required to interface with the container for transport and unloading also would be procured by the project.

11. The existing NuPac 14-210L cask would be used for shipments of the ion-exchange resin waste generated from ATR. Vaults for this waste would be sized to accept the NuPac 14-210L containers currently used at ATR. Typical cask and container handling and transfer equipment (i.e., hoisting and rigging components and a shielding bell) would be procured for the NuPac 14-210L containers as part of this project. Typical hoisting and rigging components and any ancillary equipment specific to the container design needed to unload the container from the shipping cask and to place containers into the disposal vaults would be provided by the project.

12. Performance assessment characteristics of the selected site location will not result in more restrictive waste acceptance criteria for radionuclide content than the current remote-handled vault location at RWMC.

13. A facility "liner" will be identified and included as part of the facility configuration. The exact configuration or liner component has not yet been determined. A liner alternative study will be used to identify the possible types of liners that could be incorporated, the possible impact to the facility performance assessment, and the associated cost and schedule impacts. Possible liner types that could be incorporated or used include subsurface barriers, waste isolation containers, or geochemical contaminant sorption layers. It is probable that the current waste container being used for waste disposal is determined to meet the needs of a facility "liner."

14. At this time, a Resource Conservation and Recovery Act (RCRA) subsurface barrier-type liner has been identified for inclusion in the conceptual design, even though no technical or functional requirements have been established for liners yet, nor has technical feasibility associated with the liner configuration been evaluated. It is assumed that by including this type of liner, the associated cost and schedule impacts will be bounded for all other types of liners.

15. Facility design and operational methods will be performed within the bounds established in the documented safety analysis that will be developed for the disposal facility.

16. Changes to infrastructure at waste generating facilities are not included as part of the scope of this project.

17. The Remote-Handled LLW Disposal Facility Project is based on development and approval as a line item construction project per DOE Order 413.3B, "Program and Project Management for Acquisition of Capital Assets."

\subsection{Conceptual Design Requirements Development}

A technical and functional requirements (TFR) document (TFR-483, "Remote-Handled Low-Level Waste Disposal Facility Technical and Functional Requirements") has been developed to satisfy the need for conceptual design requirements development as detailed in DOE Order 413.3B and its implementing guides. The purpose of the TFR document is to provide the requirements basis for development of the 
proposed disposal facility. To date, no requirements have been identified or established for a system liner; therefore, they are not included in the project requirements documentation.

\subsection{Summary of Technology Needs}

No new technology needs have been identified for this project. Well developed and proven technologies exist to meet requirements for disposal of remote-handled LLW.

\subsection{Systems Engineering}

A systems engineering approach has been incorporated into project planning to satisfy project requirements for a comprehensive systems engineering management process, as specified by DOE Order 413.3B and its implementing guides. The purpose of the systems engineering approach is to ensure that the Remote-Handled LLW Disposal Project applies the appropriate technical management program for the project to ensure optimal utilization of technical resources and optimal definition, application, integration, utilization, and documentation of those technical requirements important to achieving the mission and objectives.

\subsection{Value Engineering}

The systems engineering approach includes consideration of how value engineering concepts are applied during execution of the project. The project will incorporate value engineering, as required by DOE Order 430.1B, "Real Property Asset Management," and DOE Order 413.3B, as a core discipline in the implementation of the project. Beginning with planning for the project, value engineering has been incorporated through the following:

- An interdisciplinary team approach that will be used at all levels of implementation

- $\quad$ Cost/performance trade studies, which will use the value engineering methodology to identify potential options and to select a preferred option

- Design studies, which will consider value engineering recommendations in their decision making

- $\quad$ Design reviews, which will examine how effectively value engineering principles have been applied to project decisions.

Value engineering also will be applied to the functional decomposition of project requirements to ensure that all identified functions are truly required to achieve the system requirements. In the conceptual design phase, a number of alternatives to achieve project goals have been considered. In all cases, minimizing project cost (both near-term and life-cycle) while meeting project, environmental, and safety requirements was a primary discriminator in selecting the path forward. Key design options and alternative considerations are described in Section 2.7.

Following Critical Decision (CD)-1 approval and acceptance of the overall project concept and during subsequent detailed design, value engineering will be used, as applicable, to guide decisions to optimize sub-functions and sub-processes. Because the proposed design is modeled closely on existing facilities and practices, use of value engineering in this project will build on this practical experience. 


\subsection{Acquisition Strategy}

This section summarizes key points of the acquisition strategy for this project. A stand-alone acquisition strategy (DOE-ID 2011a) has been developed for the project that describes the business and technical management approach to achieving the Remote-Handled LLW Disposal Project objectives. The project consists of design and construction of a remote-handled LLW disposal facility, including the following major systems and components: procurement of prefabricated concrete vaults; site excavation; installation of vaults; design and construction of necessary support buildings; and procurement of a new commercially available waste shipping cask and transfer system.

\subsubsection{Acquisition Management}

Battelle Energy Alliance, LLC, as the management and operations contractor at INL, will act as the prime contractor for the project. The INL contract states:

The INL Contractor shall manage INL generated LLW and, if directed by DOE, $L L W$ generated by other tenants (e.g., NRF) upon closure of the RWMC LLW disposal operations... LLW management includes development of on/offsite $L L W$ disposal capability and the supporting infrastructure.

INL has a DOE-approved procurement system with established processes for handling vendor selection, construction management, and equipment procurements. INL will have prime responsibility for technical direction and oversight of all contracts required to execute this project. INL's project management, construction management, and environmental, safety, health, and quality management systems are all proven to be effective for oversight of projects of this scale and type.

\subsubsection{Business and Acquisition Approach}

The INL Remote-Handled LLW Disposal Project will be implemented as a design-build project, wherein a contract will be awarded for design and construction of the new disposal facility. This approach was chosen for the project because the project has well-defined requirements based on current remote-handled LLW disposal operations at INL, the disposal facility is not complex, and there is limited risk with the design and construction phases of the project. This design-build approach also will be used for procurement of the transport cask and transfer equipment for the ATR and MFC-generated, activated metals waste. The design-build milestone schedule is captured in Figure 2-1.

Upfront planning and documentation will focus on further clarifying the disposal facility operating requirements based on the conceptual design and subsequent analyses (e.g., nuclear safety, safeguards and security, and radiological performance assessment and composite analysis) that will augment the conceptual design package in the form of a performance specification included in the design-build procurement package. It is anticipated that using the waste container and vault configuration represented in the conceptual design, the waste containers (or liners) will be sufficient to address the issues and concerns in regard to providing a lined waste disposal facility. If other liner configurations are incorporated, an evaluation will need to be performed to address the differences in facility configuration to determine if the implemented configuration remains within the bounds of the well known and operational facilities. The performance specification will include sufficient information needed to allow prospective contractors to prepare high quality and comprehensive bids or proposals for project final design and construction. The overall objective of completing the INL Remote-Handled LLW Disposal Project using a design-build approach is to reduce the total cost of the project and to provide uninterrupted remote-handled LLW disposal capability through a process that can be completed quicker than a traditional design-bid-build approach. 


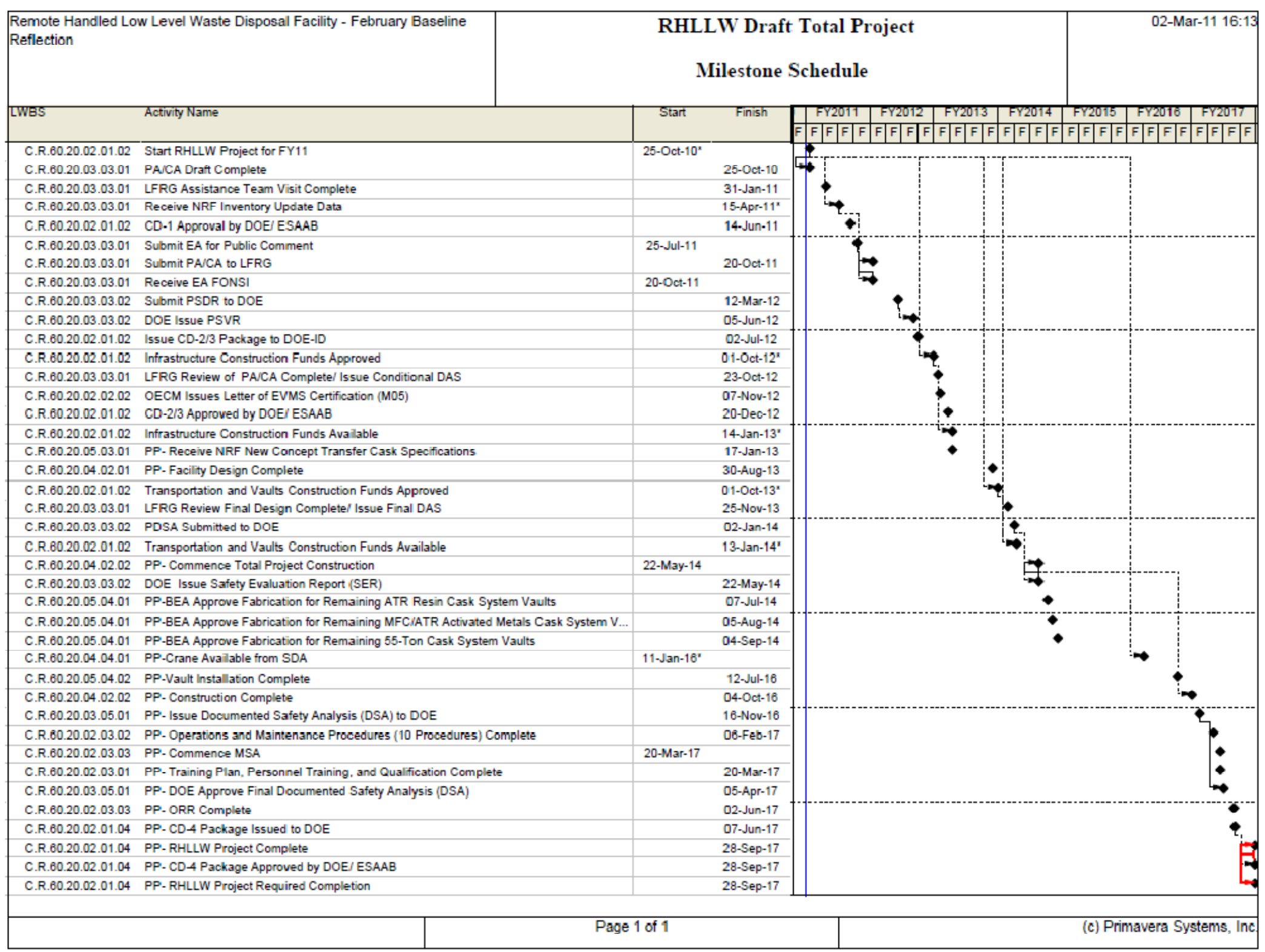

Figure 2-1. Remote-Handled Low-Level Waste Disposal Project timeline. 


\subsubsection{Acquisition Risks}

In accordance with DOE guidance (DOE Guide 413.3-13), risks associated with acquisition were identified. The risks considered for selection of the acquisition strategy fall into the following categories:

- $\quad$ Funding and budget

- $\quad$ Legal and regulatory

- $\quad$ Location and site conditions

- $\quad$ Cost and schedule

- Functional

- $\quad$ Scope and definition

- Interfaces

- $\quad$ Stakeholder issues.

Specific risks and mitigation actions are identified. Criteria also are established for use in selecting a preferred acquisition strategy. The design-build approach meets the established criteria. Table 2-1 provides a summary of the risks by category, their mitigations, and the criteria.

\subsubsection{Interfaces and Integration Requirements}

To successfully provide uninterrupted disposal capacity for INL remote-handled LLW, the chosen alternative must be compatible and must interface with facilities, equipment, material handling tools, and operating procedures currently in use at RWMC. Continuing use of functional equipment and efficient processes will reduce cost, simplify, and improve safety of disposal operations and associated activities. The primary project interface with the generating facilities will be associated with the waste containers and transport casks. The project will work closely with the generating facilities to ensure compatibility between any new waste transport system(s) and the concrete disposal vaults.

\subsection{Design Options}

In accordance with the requirements of DOE Order 413.3B and its implementing guides, an evaluation of design options has been performed to identify the preferred design of the proposed facility. This section provides a description of design options and processes used to arrive at selection of the design option used for the conceptual design basis in this report.

\subsubsection{Design Options Set Selection}

An analysis of design options for the proposed onsite disposal facility was conducted as part of conceptual design development. The design team started the analysis by evaluating the initial TFRs for the proposed facility and their ability to be achieved through various design options. The design options that could fulfill the TFRs were selected for further review. These design options were evaluated to assess cost and ease of implementation. Selected design options are incorporated into the conceptual design. 
Table 2-1. Risk analysis for the Remote-Handled Low-Level Waste Disposal Project.

\begin{tabular}{ll} 
Risk Category & \multicolumn{1}{c}{ Risk Definition } \\
\hline Funding and & If project funding is not received or is \\
Budget & $\begin{array}{l}\text { delayed during project execution (due to lack } \\
\text { of priority or difficulty in government } \\
\text { funding cycles), planned critical path } \\
\text { activities may be impacted. }\end{array}$
\end{tabular}

Mitigation Action(s)

Criteria for Acquisition Strategy

- Ensure a clear prioritization strategy for funding

- Work with DOE Headquarters for prioritization of funding

- Streamline critical path activities

- Ensure budget for consistent project management.

Legal and If the environmental assessment does not

Regulatory result in a finding of no significant impact, then an environmental impact statement is required.

If a stakeholder(s) files lawsuit against DOE, then significant delays will result.
If an updated Natural Phenomena Hazard Assessment for the INL site identifies new deficiencies that require design changes, then significant cost and schedule impacts will result.
- Clearly defined NEPA strategy

- Defined project requirements that minimize environmental impacts

- Actively employ communication strategy to engage DOE Headquarters.

- Clearly defined NEPA strategy with strict adherence to the NEPA process

- Actively employ communication strategy to engage the public.

- Communicate within DOE to accomplish necessary analyses

- Proven design that provides protective measures from natural hazards

- Effective communication with DOE

Headquarters and Office of Engineering and Construction Management.

- Contractor available with proven technical and regulatory capabilities to support NEPA analysis.

- Proven federal or contractor capability to communicate with stakeholders.

- Communicate within DOE to accomplish necessary analyses

- Proved design that provides protective measures for natural hazards

- Maintain frequent and effective communication and interface with DOE-NE Headquarters and DOE

Office of Engineering and Construction Management

- Proven technical and engineering capabilities available to integrate siting and nuclear safety aspects into design criteria.

Interfaces and If CD-4 (likely all CD approvals) is not Integration approved on schedule, then the facility may not be operational by the required date and significant programmatic impacts would be imposed on generators (MFC/ATR/NRF).
- Management assessments at start of construction

- Actively employ a communication strategy between DOE Idaho Operations Office and DOE Headquarters on CD approach and approval.
- Proven contractor capability to maintain critical path schedule. 
Table 2-1. (continued).

\begin{tabular}{|c|c|c|c|}
\hline Risk Category & Risk Definition & Mitigation Action(s) & Criteria for Acquisition Strategy \\
\hline \multirow[t]{2}{*}{$\begin{array}{l}\text { Stakeholder } \\
\text { Issues }\end{array}$} & $\begin{array}{l}\text { If there is stakeholder resistance to siting and } \\
\text { construction of a remote-handled LLW } \\
\text { disposal facility at INL, then a protracted } \\
\text { schedule and increased costs, resulting from } \\
\text { activities necessary to resolve stakeholder } \\
\text { issues, would result. }\end{array}$ & $\begin{array}{l}\text { - Actively employ a communication strategy to } \\
\text { engage the public } \\
\text { - Performance Assessment/Composite Analysis } \\
\text { proof of low health and safety risk. }\end{array}$ & $\begin{array}{l}\text { Proven federal or contractor } \\
\text { capability to communicate with } \\
\text { stakeholders } \\
\text { - } \quad \begin{array}{l}\text { Proven federal or contractor } \\
\text { performance assessment expertise. }\end{array}\end{array}$ \\
\hline & $\begin{array}{l}\text { If the Greater-Than-Class C environmental } \\
\text { impact statement is issued, where INL is a } \\
\text { potential disposal site, stakeholders' } \\
\text { perceptions that the new onsite disposal } \\
\text { facility will be expanded to include Greater- } \\
\text { Than-Class C would result. This will cause } \\
\text { significant resistance and subsequent delays. }\end{array}$ & $\begin{array}{l}\text { - Monitor progress of the Greater-Than-Class C } \\
\text { environmental impact statement decisions that } \\
\text { could affect INL } \\
\text { - Actively employ a communication strategy to } \\
\text { engage the public } \\
\text { - Actively employ communication strategy to } \\
\text { engage DOE Headquarters. }\end{array}$ & $\begin{array}{l}\text { Proven federal or contractor } \\
\text { capability to communicate with } \\
\text { stakeholders. }\end{array}$ \\
\hline $\begin{array}{l}\text { Expertise and } \\
\text { Human } \\
\text { Resources }\end{array}$ & $\begin{array}{l}\text { If the design/build philosophy requires a } \\
\text { vendor to interpret safety basis and QA } \\
\text { related requirements, then issues may not be } \\
\text { identified (or not identified early enough) } \\
\text { resulting in significant construction rework. }\end{array}$ & 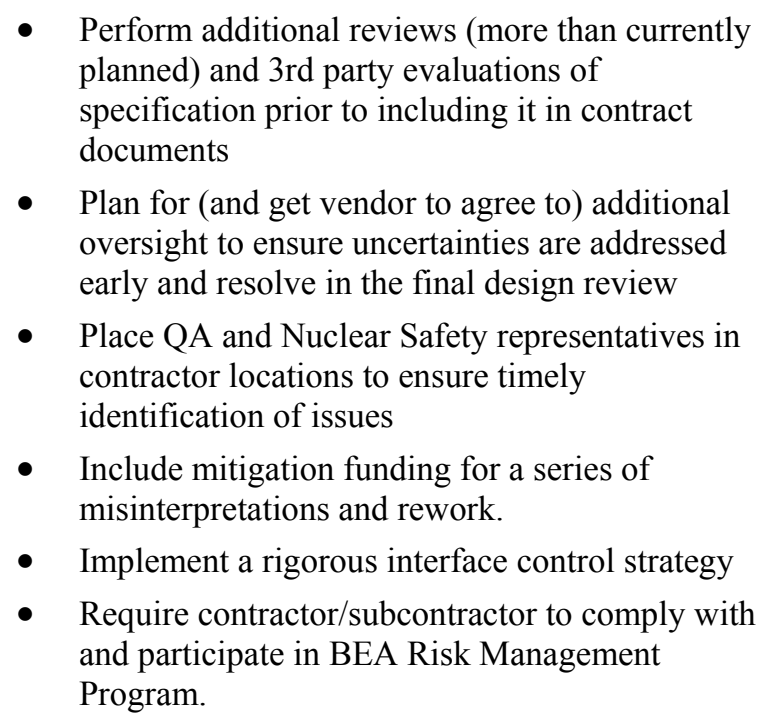 & $\begin{array}{l}\text { Proven federal or contractor } \\
\text { capability to provide expert } \\
\text { technical oversight. }\end{array}$ \\
\hline
\end{tabular}


Based on the remote-handled LLW alternatives analysis (INL 2011) and review of the design elements of the existing disposal facility and associated operations, it was determined that the design approach for the disposal vaults in the proposed remote-handled LLW disposal facility should closely parallel that of the existing disposal vaults at RWMC. Based on this design approach, design options were identified. Design options developed for further consideration are as follows:

1. Installation of vaults versus use of boreholes (soil vaults)

2. Incorporation of system liners in addition to the vaults

3. Installation in surficial sediment versus installation in basalt formation

4. Installation of vaults that would accommodate multiple transport cask and waste container dimensions

5. Engineered intruder barriers.

\subsubsection{Evaluation of Design Options}

This section describes the design options evaluated during conceptual design.

2.7.2.1 Installation of Vaults versus Use of Boreholes. One alternative design consideration is the possibility of drilling boreholes and directly inserting containers of remote-handled LLW. This method was used at RWMC before 1992 to dispose of remote-handled LLW. In 1992, the first set of concrete vaults was installed to accept remote-handled waste. Compared to using boreholes, concrete vaults offered a number of significant advantages. Use of concrete vaults allows the minimum center-tocenter distance to be obtained while maintaining structural stability. This minimizes the footprint of the facility and provides increased stability. Infiltration of sidewall materials into the borehole could interfere with placement of the remote-handled LLW containers. To minimize this type of event, much greater center-to-center distances are required for boreholes than for placement of concrete vaults. By using concrete vaults, operations are both simplified and made more predictable. In view of the lessons learned from actual operations, the option of using boreholes without vaults was discarded.

2.7.2.2 Incorporation of System Liners in Addition to Vaults. On the basis of national policy and strategies for safe disposal of radioactive waste, the project will complete appropriate safety assessments and activities needed for siting, design, construction, operation, and closure of the remote-handled LLW disposal facility. The final vault configuration will be based on these safety assessments. However, in line with recent discussion within DOE, liners will be considered as part of this project. A liner evaluation, using a systems engineering development approach, will be performed to evaluate and assess liner options. This includes the analysis of design needs and alternatives that could be incorporated into the facility configuration to ensure optimization of design and to maximize facility performance. A number of different types of liners will be evaluated to determine the best "liner" component to incorporate into the design. The systems approach will include the following points of concern:

- $\quad$ The facility will be designed to provide adequate isolation of disposed waste for the required time periods that are applicable to the specific waste materials and characteristics and the specific site safety requirements.

- The design will minimize the need for active maintenance after closure. 
- $\quad$ The disposal facility may include engineered barriers, which together with the emplaced medium and its surroundings, isolate the waste from humans and the environment. The engineered barriers may consist of the waste package and other human-made features (i.e., vaults, covers, linings, grouts, and backfills) that are intended to prevent or delay radionuclide migration from the facility to the surroundings.

- The initial evaluations, which are primarily based on the existing vault and disposal configuration established at RWMC, indicate that there is not a need for additional liner systems within the facility configuration. However, the initial evaluation was centered primarily on the possible use of a subsurface liner and associated leachate collection system. These Resource Conservation and Recovery Act (RCRA)-type liners are a design base requirement for EPA's management of hazardous waste. They are not used for LLW disposal facilities because of the need to avoid water accumulation in the disposal unit. Use of a low permeability membrane below the disposal zone could potentially result in accumulation of water in the disposal unit. This is further supported by 10 Code of Federal Regulations (CFR) 61.51, "Disposal Site Design," criteria that states that allowing free drainage from the disposal units is actually desirable:

Reducing the contact time of water with the waste by using freely-draining granular backfill should be considered. In addition, the accumulation of water in the disposal unit (the bathtub effect) must be avoided. This can normally be accomplished if the bottom of the disposal unit can drain at least as readily as water can infiltrate into the disposal unit through the cover or sides....

An additional project liner alternative analysis that addresses the requirements established in the International Atomic Energy Agency guidance documents (IAEA, IAEA 1999, IAEA 2006) for near surface disposal of radioactive waste will be completed during development of the facility-specific final performance specification in the CD-2 timeframe. The alternatives analysis will include the option to select the existing waste container as the system "liner," and it will use this alternative as the base case to which other alternatives will be compared. The alternatives analysis will include the following:

1. Identify potential liners that could be incorporated into the final facility design, while maintaining the overall operational approach currently used for the RWMC disposal vaults. These liner types could possibly include steel waste isolation containers, subsurface geosynthetic, high density polyethylene and clay material that may or may not allow infiltration and eliminate the need for an additional leachate collection system, geochemical barrier (adsorption trap), and other covers and linings that may trap the radionuclide contaminants and help prevent the long term migration of the radionuclides.

2. Down select from the potential alternatives and identify the liners that justify further evaluation and possible incorporation into the system development approach.

3. Evaluate the geochemical impacts to geochemical sorption traps and material sorption rates.

4. Develop a geochemical transport (hydrogeochemical) model of the vault system. This will provide a model of how the vault system should work and to assess the long-term behavior of the concrete vaults and their impact on the sorption of the underlaying materials.

5. Model the different liner alternatives to estimate waste migration concentrations and evaluate the expected radiological dose over time.

6. Complete a cost benefit analysis for the various alternatives. 
The final results of the alternative analysis will be incorporated into the facility performance specifications that will be used for the design-build procurement, which will include final design and system construction activities.

\subsubsection{Installation in Surficial Sediment versus Installation in Basalt Formations.}

Design consideration was given to drilling boreholes in basalt formations instead of surficial sediment. The potential for fractures in basalt either as a result of drilling or due to other influences would lead to potential fissure pathways to the aquifer, which could significantly accelerate pathways for release of contaminants to the groundwater exposure pathway. This potential accelerated release could adversely affect the total radionuclide inventory permitted for disposal by the performance assessment.

\subsubsection{Installation of Vaults that will Accommodate Multiple Transport Cask and}

Waste Container Dimensions. Design of the vaults for disposal of remote-handled LLW is greatly dependent on the size of the waste containers (also called cask liners) that would be disposed of at the facility. The vaults will be sized to accommodate the existing or planned waste containers from NRF, ATR, and MFC. The waste container, cask, and transfer system for disposal of NRF activated metals and resin waste streams have been successfully used for many years. Alteration of any elements of this system would result in significant costs and possible interruptions in the current NRF operations. Recent indications have been made that NRF is going to build a new fuel processing facility that will use different waste packaging and shipping containers. If they do so, the specified vaults for the NRF waste may need to be revised to accommodate the new waste containers and overall volume. The changes are not expected to be implemented until the 2023 timeframe. In addition, no such alterations are likely to have a significant impact on costs of design or construction of the proposed vault system or result in cost savings during operation if the changes are identified prior to the completion of the disposal facility final design. Therefore, the proposed vault design for disposal of the 55-ton scrap cask waste containers is based on the RWMC vaults, which are suitable for the containers used by NRF for transport of remotehandled LLW. These vaults are made from precast concrete. They have a circular cross section and are approximately $5 \mathrm{ft}(1.5 \mathrm{~m})$ in diameter and $20 \mathrm{ft}(6 \mathrm{~m})$ high. They can accommodate two stacked 55-ton cask waste containers (47-in. [119-cm] diameter $\times 104$ in. [264. cm] high). Each container holds approximately $90 \mathrm{ft}^{3}\left(3 \mathrm{~m}^{3}\right)$ of waste.

ATR and MFC remote-handled LLW activated metal waste streams are anticipated to be transported in a commercially available cask. The proposed design of the vaults for the ATR and MFC activated metal waste streams is similar to the design used for the 55-ton scrap cask waste container vaults currently used at RWMC for NRF waste but sized to accommodate container dimensions for a commercially available cask. The vaults would be made from precast concrete. They would have a circular cross section and would be approximately $4 \mathrm{ft}(1.3 \mathrm{~m})$ in diameter and $20 \mathrm{ft}(6 \mathrm{~m})$ high. They could accommodate two stacked waste containers $(3 \mathrm{ft}[1 \mathrm{~m}]$ diameter $\times 9.25 \mathrm{ft}[2.8 \mathrm{~m}]$ high $)$. Each container could hold approximately $60 \mathrm{ft}^{3}\left(1.5 \mathrm{~m}^{3}\right)$ of waste. The actual containers used for packaging the remote-handled LLW for transport using a commercial available cask would be selected (or designed) and procured by the project.

The ATR ion-exchange resins will be transported in the NuPac 14-210L cask. The ATR ion-exchange resin vault also will be similar to the current design used at RWMC, but sized to accommodate the NuPac 14-210L container. Vaults would be made from precast concrete, have a circular cross section, and would be approximately $7 \mathrm{ft}(2.1 \mathrm{~m})$ in diameter and $16 \mathrm{ft}(4.9 \mathrm{~m})$ high. They could accommodate two stacked containers $(6.25 \mathrm{ft}[1.9 \mathrm{~m}]$ diameter $\times 6.25 \mathrm{ft}[1.9 \mathrm{~m}] \mathrm{high})$. Each container could hold $210 \mathrm{ft}^{3}\left(6 \mathrm{~m}^{3}\right)$ of waste. However, the containers would be loaded with an average of $128 \mathrm{ft}^{3}$ $\left(3.6 \mathrm{~m}^{3}\right)$ of waste. 
2.7.2.5 Performance Assessment Required/Enhancing Barriers. The current design used at RWMC allows use of additional stainless steel barrier plates on top of the containers inside the vaults. The purpose of these barrier plates is to delay the time horizon needed for an inadvertent intruder to penetrate the disposal vaults and bring radioactive material to the surface. The timeframe available for decay is critical to establishment of the maximum concentrations and radionuclide distribution permitted for disposal by the radiological performance assessment. This additional barrier was judged to be an appropriate design feature that would allow for disposal of both a greater total inventory and broadening the characteristics of the waste permitted under the facility waste acceptance criteria. Therefore, the dimensional configuration of the conceptual design of the vaults allows for the use of such plates in the proposed disposal facility.

\subsubsection{Conclusions of Design Options Evaluation}

Based on this analysis and operational experience at RWMC, the proposed onsite facility design would dispose of all identified remote-handled LLW waste streams in concrete vaults, which would be placed in an unlined, sedimentary soil bed. It should be noted that a conceptual approach of including a subsurface liner is shown in the conceptual drawings provided in Appendix A; however, this is only provided to represent the most conservative approach that may be determined during the final design process. Currently, no physical or operation requirements are identified that indicate the need for the subsurface liner. The proposed configuration of concrete vaults is based on the RWMC vaults, which are sized to accommodate the 55-ton cask waste container currently used by NRF for transport of remotehandled LLW. Vaults of similar design, but sized to accommodate the waste container dimensions used for the ATR resins and the waste container dimensions anticipated for the ATR and MFC activated metals, also would be installed. If future cask and waste container systems identified for use differ from those described herein, the design would be modified during the final design to account for these differences. Any known differences will be described in the facility performance specification for use in the design-build procurement. The number of vaults proposed is based on the estimated waste stream generation rates anticipated from the generator facilities.

Construction of the proposed disposal facility involves installation of concrete vaults for remote-handled LLW activated metals and ion-exchange resin waste streams. However, none of the selected design features are based on characteristics unique to activated metals or ion-exchange resin waste streams, and therefore should not, in and of themselves, limit the type of remote-handled waste that could be disposed of in the facility. In accordance with DOE Order 435.1, specific waste acceptance criteria, based on the performance assessment and composite analysis, will be established for the proposed facility.

\subsection{Site Selection}

A site location must be selected in order to develop the highest ranked alternative identified in the alternatives analysis (INL 2011) at INL (i.e., operate a new onsite remote-handled LLW disposal facility [onsite disposal]). A siting study was conducted to support evaluation of the onsite disposal alternative (INL 2010c). The study identifies candidate locations at INL and evaluates them against technical and programmatic objectives for remote-handled LLW disposal. A comprehensive analysis of siting options involves identification of appropriate site selection criteria that address regulatory, facility design, facility performance, and key project assumptions. The siting study for the Remote-Handled Low-Level Waste Project (INL 2010c) documents systematic development of criteria, building on previous siting studies conducted at INL and unique requirements associated with the Remote-Handled LLW Disposal Project. The site selection criteria were applied to potential site locations in order to assess each site's suitability for a remote-handled LLW disposal facility. 
Development of a site location recommendation for onsite disposal at INL is subject to the requirements of DOE Order 435.1 and implementing guidance for LLW disposal facilities. The siting study considered environmental characteristics, geotechnical characteristics, and human activities. It specifically addresses the following:

- $\quad$ Suitability for volume of waste

- $\quad$ Flood plain

- $\quad$ Tectonic activity

- Water table fluctuation

- Access

- Wildlife

- Whether radionuclide migration pathways are predictable

- Whether erosion and surface runoff can be controlled.

Substantial data regarding site conditions are available from routine environmental monitoring, sampling and analysis, other studies, and previous siting studies for other facilities at INL (Holdren et al. 1997; Spry et al. 1989; Taylor et al. 1994; DOE-ID 1999). This body of knowledge was used to develop "must" and "want" site selection criteria that were focused on the specific needs of a remote-handled LLW disposal facility.

Previous INL siting studies provide detailed examples of the development and application of evaluation criteria and ranking strategies. Review of these previous siting studies indicates that the following five key areas are the primary contributors to the synthesis of information and requirements used for development of a comprehensive set of siting criteria:

1. Regulations

2. Key assumptions

3. Conceptual design

4. Facility performance

5. Previous siting study criteria.

The evaluation process identifies regulations, codes, and directives that may be applicable to siting such a facility or that are useful in determining specific evaluation criteria. Siting criteria derived from the five areas address requirements that are important during the operational life of the facility and requirements that give consideration to post-closure performance over longer timeframes. A thorough analysis of the five key areas is provided.

The evaluation process implements a methodology derived from the strategies used in previous siting studies. In summary, "Must" (critical features that are needed) and "Want" (important features that may enhance facility performance or reduce its effects on the environment) criteria were established and 
weighted based on relative significance. The five steps of the process used for this evaluation are as follows:

1. Identify criteria (both "Must" and "Want")

2. Identify candidate sites

3. Apply "Must" screening criteria to all candidate sites

4. Apply "Want" criteria to sites passing the "Must" screening

5. Rank candidate sites and recommend the most suitable site(s).

The selection of "Must" and "Want" criteria is documented, with a total of 53 criteria identified and evaluated for use. The criteria evaluation resulted in identification of four "Must" criteria and 21 "Want" criteria to be used in the siting evaluation.

An assessment of 34 candidate sites against the established criteria also was conducted. Two sites are recommended for consideration in the NEPA process. A site walk-down was conducted at the three highest-ranked sites to review site-specific conditions and verify that individual sites were appropriately recommended for further consideration through the NEPA process. The two locations that best meet the evaluation criteria are (1) near ATR and (2) west of the Idaho CERCLA Disposal Facility.

\subsection{Staffing Requirements}

Anticipated staffing requirements are based on current staffing for remote-handled LLW disposal operations at RWMC. It is estimated that 11 personnel will be required to support proposed disposal operations. Disposal operations are estimated to be conducted on a frequency of one to two disposal campaigns per month with a 3-day duration each. The following types of skills or functions will be needed to staff proposed remote-handled LLW disposal operations:

- $\quad$ Two heavy equipment operators

- $\quad$ Two equipment operators

- Two radiological control technicians

- Gate guard/security

- Quality control inspector

- $\quad$ Subject matter expert from generating facility

- Mechanic

- $\quad$ Shipping coordinator.

Additional staff and operational personnel will be required if a subsurface liner and water collection system is incorporated into the disposal system. In general, these activities would include the need to provide daily inspections of the water collection system and the need to remove and process any 
water found present in the system. Personnel needed to support these activities would include the following:

- Two field technicians

- One environmental/sampling coordinator

- Up to three sample collection/shipping and analytical technicians.

\subsection{Codes, Standards, and Regulations}

The following codes, standards, and regulations were evaluated during the conceptual design process and are applicable throughout the final design and construction process:

- $\quad 10$ CFR 830, Subpart A, “Quality Assurance Requirements," Code of Federal Regulations, Office of the Federal Register, February 4, 2002.

- $\quad 10$ CFR 835, “Occupational Radiation Protection," Code of Federal Regulations, Office of the Federal Register, July 11, 2007.

- $\quad 10$ CFR 851, "Worker Safety and Health Program," Code of Federal Regulations, Office of the Federal Register, February 9, 2006.

- $\quad 29$ CFR 1910, "Occupational Safety and Health Standards," Code of Federal Regulations, Office of the Federal Register, February 15, 2008.

- $\quad 29$ CFR 1926, "Safety and Health Regulations for Construction," Code of Federal Regulations, Office of the Federal Register, February 15, 2008.

- $\quad$ ACI-318/99, "Building Code Requirements for Structural Concrete with Commentary," American Concrete Institute, Farmington Hills, MI.

- $\quad$ ANSI/ANS 2.26-2004, "Categorization of Nuclear Facility Structures, Systems and Components for Seismic Design,” American National Standards Institute/American Nuclear Society.

- $\quad$ ASCE/SEI 43-05, "Seismic Design Criteria for Structures, Systems, and Components in Nuclear Facilities,” American Society of Civil Engineers/Structural Engineering Institute.

- $\quad$ ASME NQA-1-2000, "Quality Assurance Requirements for Nuclear Facility Applications," American Society of Mechanical Engineers, January 2000.

- $\quad$ ASTM Book of Standards, Volume 04.02, "Construction: Concrete and Aggregates," American Society for Testing and Materials International, West Conshohocken, PA.

- $\quad$ DOE Order 420.1B, “Facility Safety,” U.S. Department of Energy, December 22, 2005.

- DOE Order 435.1, "Radioactive Waste Management," Change 1, U.S. Department of Energy, July 9, 1999. 
- DOE Order 5400.1, "General Environmental Protection Program," Change 1, U.S. Department of Energy, June 29, 1990.

- $\quad$ DOE Order 5400.5, "Radiation Protection of the Public and the Environment," Change 2, U.S. Department of Energy, January 7, 1993.

- $\quad$ DOE-STD-1020-02, "Natural Phenomena Hazards Design and Evaluation Criteria for Department of Energy Facilities," U.S. Department of Energy, January 2002.

- DOE-STD-1021-93, "Natural Phenomena Hazards Performance Categorization Guidelines for Structures, Systems, and Components," Change 1, U.S. Department of Energy, January 1996.

- $\quad$ DOE-STD-1027-92, "Hazard Categorization and Accident Analysis Techniques for Compliance with DOE Order 5480.23, Nuclear Safety Analysis Reports," U.S. Department of Energy, December 1992 (including Change 1, September 1997).

- $\quad$ DOE-STD-1090-07, "Hoisting and Rigging Standard,” U.S. Department of Energy, 2007.

- DOE-STD-1189-2008, "Integration of Safety into the Design Process,” U.S. Department of Energy, March 2008.

- $\quad$ IBC, 2009, International Building Code, International Code Council.

- $\quad$ PCI MNL 116, "Manual for Quality Control for Plant and Production of Precast and Prestressed Concrete," 4th Edition, Precast and Prestressed Concrete Institute, 1999.

- $\quad$ PCI MNL 120, "Prestressed Concrete Institute Design Handbook for Precast and Prestressed Concrete," 6th Edition, Precast and Prestressed Concrete Institute, 2004.

- $\quad$ STD-139, “INL Engineering Standards,” Idaho National Laboratory. 


\section{PROCESS SUMMARY}

The design of the proposed remote-handled LLW facility described in this conceptual design report is similar to the design of the existing facility at RWMC. Operation of this new facility would likewise be similar to the existing operation to minimize operational costs and time delays and to maximize efficiency by using current and existing procedures, processes, and equipment.

This section describes the overall process used for disposal of remote-handled LLW at INL. Figure 3-1 shows the general process that is currently being used for remote-handled LLW disposal at RWMC. It is assumed that future waste received from each of the INL generating facilities would be received and disposed of using this same, or similar, sequence of activities. This process is the basis for development of the TFRs for the new disposal facility.

\section{Waste Receipt and Staging}

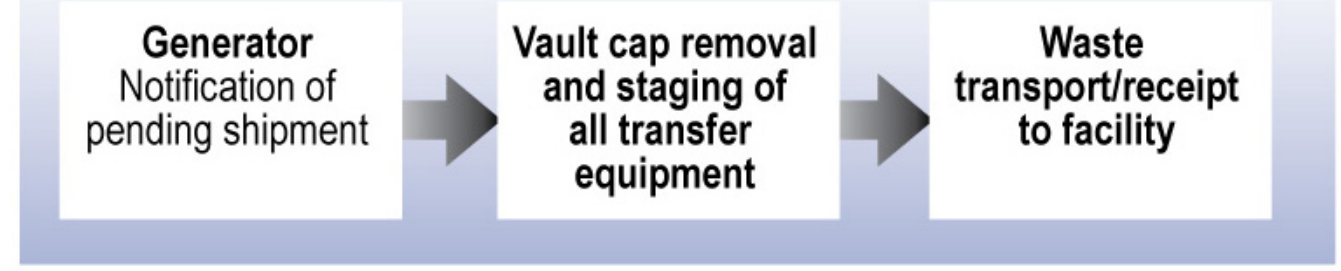

\section{Disposal}

\section{Cask staging and placement for vault loading}

\section{Waste liner transferred from cask and placed in vault}

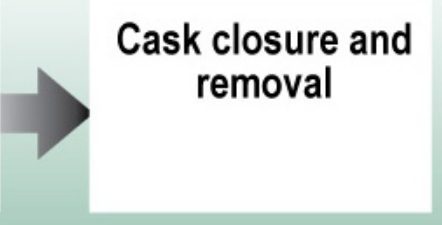

\section{Vault Closure and Demobilization}

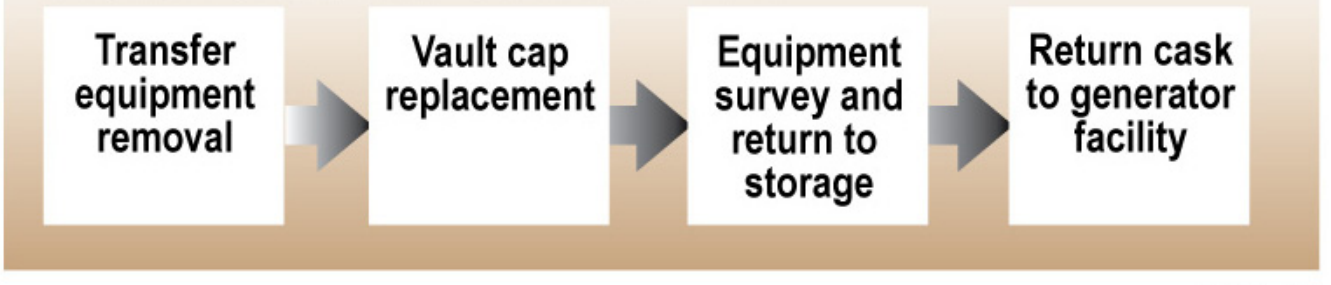

NW09-120

Figure 3-1. Facility process diagram.

The general sequence used for receiving and disposal of the remote-handled LLW shipments currently received at RWMC consists of the following:

1. Once waste is transported to the site, a crane is used to remove the top plug on the vault and to position the cask-to-vault adapting structure (CVAS) on top of the open vault

2. The 55-ton scrap cask is removed from the transporter and placed on the CVAS using the crane 
3. Using a remote-operated hoisting system, the waste container is unloaded from the bottom of the cask and lowered into the disposal vault

4. The cask is then closed and the hoisting system with the associated equipment is removed from the top of the vault

5. The vault is closed.

The specific operational systems and placement procedures that will be used in association with the other cask systems used for disposal of the remote-handled LLW at the proposed facility will be determined once the generating facilities identify their specific waste container configurations. It is assumed that the following general operational sequence would be used for placement of the waste containers into the associated disposal vaults:

1. Once waste is transported to the site, a crane will be used to remove the top plug on the vault and prepare the vault opening for container placement

2. Using the crane, the waste container will be removed from the cask using the associated container handling equipment and positioned over the disposal vault

3. The waste container will be lowered into the disposal vault

4. The bell and transfer equipment will be removed and the vault plug replaced.

\subsection{Process Description}

Currently, remote-handled LLW shipments are transported from NRF to RWMC in a 55-ton scrap cask (Figure 3-2). The waste is placed in steel waste containers, also called cask liners, which are 47 in. $(119 \mathrm{~cm})$ in diameter and 104 in. $(264 \mathrm{~cm})$ long (Figure 3-3). Each scrap cask contains a single sealed and vented waste container. Each of the existing disposal vaults at RWMC can accept two waste containers. As vaults are filled, a 2-ft $(0.6-\mathrm{m})$ thick soil/gravel cover is placed over the concrete plugs and used as a working surface for the crane to allow close setup of equipment for other vaults.

This same process would be used in the new disposal facility. It is anticipated that other waste packages (i.e., cask waste containers) would be developed and used for activated metal waste generated at ATR and MFC from new missions and from processing remote-handled scrap and waste currently stored at MFC's Radioactive Scrap and Waste Facility. For the conceptual design, it is assumed that this waste would be unloaded and placed in disposal vaults using a method similar to that described in Figure 3-1. The actual containers used for packaging the remote-handled LLW for transport will be selected (or designed) and procured by the individual operating/generating facilities. Any ancillary equipment specifically required to interface with the waste container for transport and unloading, other than the typical hoisting and rigging components, will be provided by the generating facility.

Based on the conceptual design, the proposed remote-handled LLW disposal facility would provide approximately 247 new disposal vaults that are similar to the existing RWMC vault design. The vaults would be constructed of precast concrete cylinders (i.e., pipe sections) stacked on end and placed within an array, as shown in Figure 3-4. This configuration would provide the ability to dispose of the desired quantity of waste within the smallest footprint possible. 


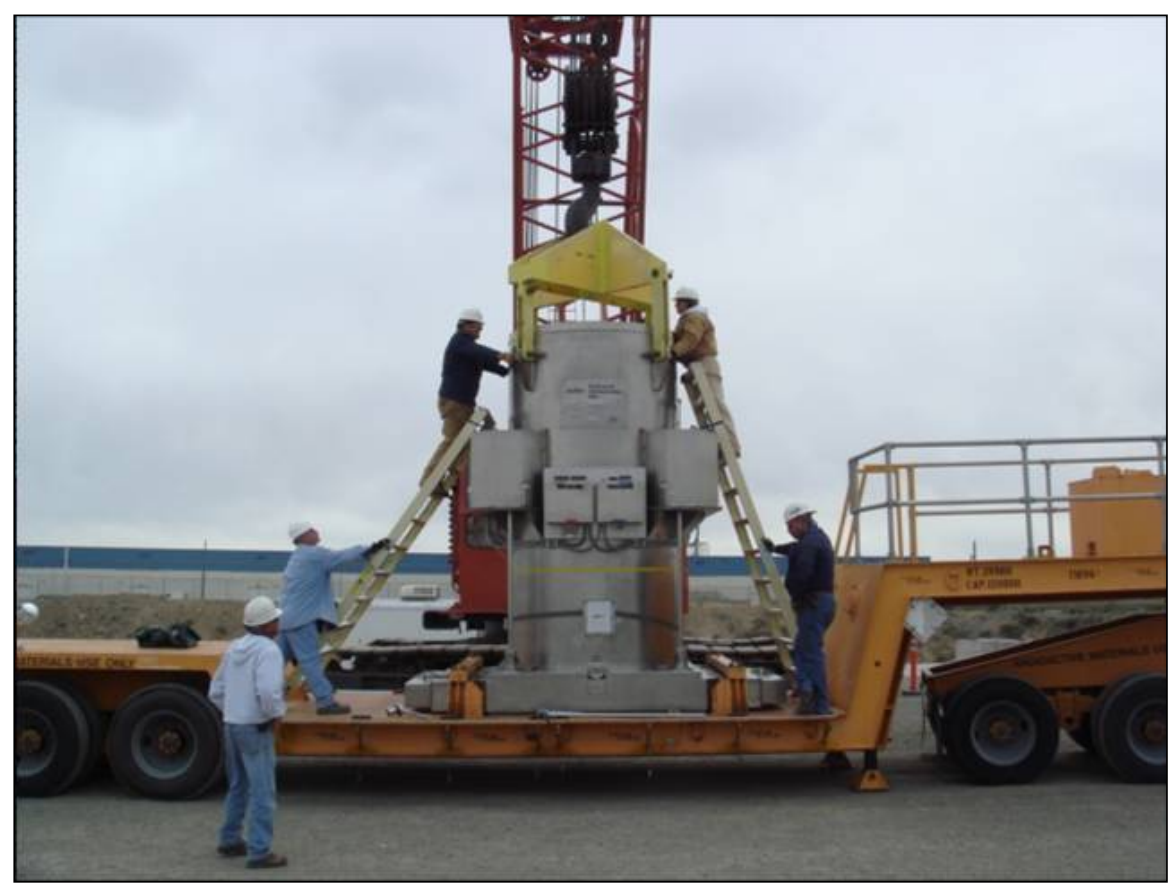

Figure 3-2. A 55-ton scrap cask used for transporting waste to the disposal facility.

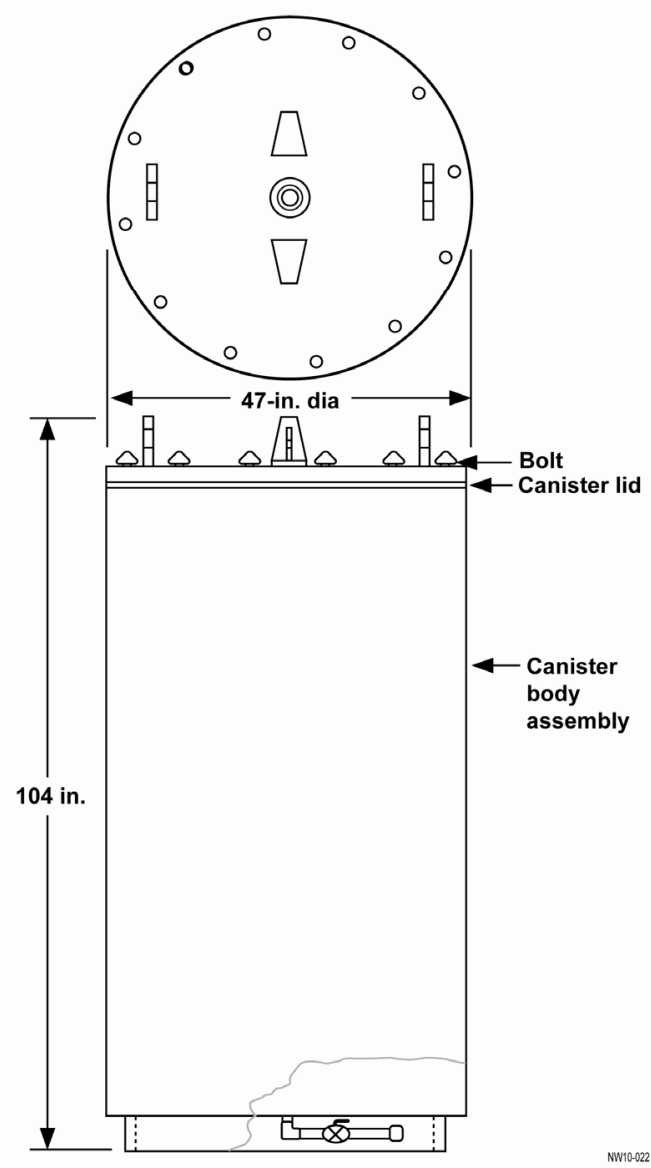

Figure 3-3. Waste container used inside the 55-ton scrap cask. 


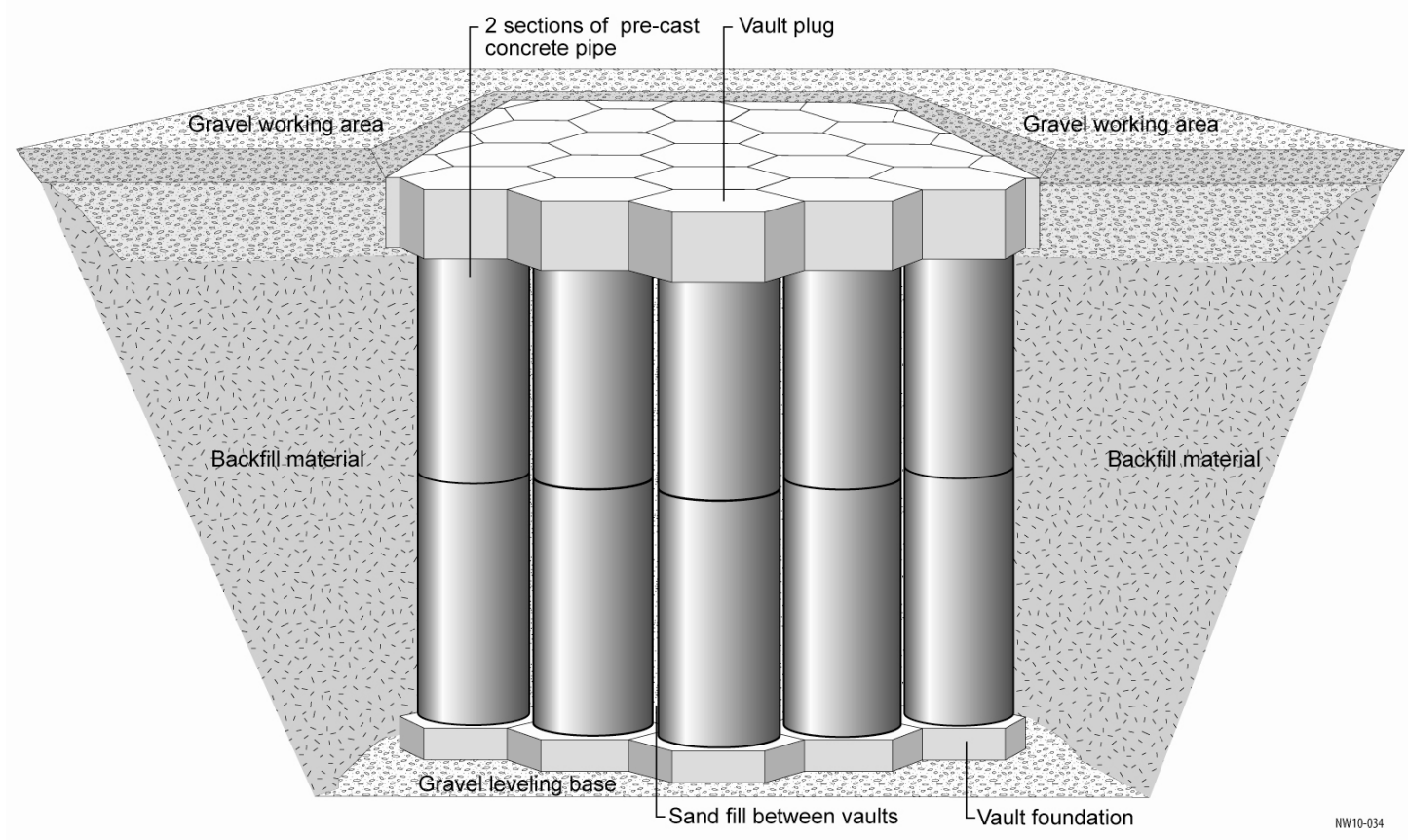

Figure 3-4. Concrete vault layout.

Specific design and operational objectives for the proposed disposal facility include the following:

1. Providing a concrete vault disposal system that can accommodate waste containers that are currently being used for waste disposal of remote-handled LLW activated metals and ion-exchange resins generated at NRF.

2. Providing a concrete vault disposal system that can accommodate waste containers that are anticipated to be used for disposal of remote-handled LLW activated metals generated at ATR and MFC.

3. Providing a concrete vault disposal system that can accommodate waste containers that currently are being used for disposal of remote-handled LLW ATR resins.

4. Accommodating waste container placement methods currently in use at RWMC, and continuing to use the existing remote-handled loading equipment and proven waste disposal procedures for the NRF shipping cask.

5. Providing support and shielding equipment needed to unload waste containers that are anticipated to be used by ATR and MFC.

6. Providing road access that can accommodate anticipated loads from cask transport vehicles.

7. Placing waste containers into vaults while providing the appropriate level of shielding and worker protection.

8. Providing a vault/plug assembly to provide shielding, minimize entry of water into the vaults, and allow drainage of any moisture/condensate that accumulates inside the vaults. 
9. Allowing access to individual vaults without disturbing adjacent vaults.

10. Providing crane access areas to support placement of waste materials into the vaults, as needed, that will support the combined weight of a loaded crane during placement. The total weight would include the crane, cask, cask-to-vault adapter components, shielding/sealing plug, and waste containers.

11. Providing shielding sufficient to reduce radiation levels on top of the vaults, when the plugs are in place, to levels specified in DOE Order 5400.5, "Radiation Protection of the Public and the Environment."

\subsection{Anticipated Waste Streams}

Remote-handled LLW is radioactive waste that requires shielding to protect people from radiation exposure. By definition, remote-handled LLW is low-level radioactive waste that has a radiation exposure rate at the outer surface of the container that is greater than $200 \mathrm{mR} /$ hour

The remote-handled LLW activated metals waste stream will be generated at NRF, ATR, and MFC. This waste is remote-handled LLW, non-hazardous radioactive metals with external radiation fields that range from $200 \mathrm{mR} /$ hour up to $30,000 \mathrm{R} /$ hour. The remote-handled LLW waste stream also will include ion-exchange resins generated at NRF and ATR. A description of the anticipated waste streams from each generating facility is included in Table 3-1.

Table 3-1. Remote-handled low-level waste stream descriptions.

\begin{tabular}{ccl}
\hline $\begin{array}{c}\text { Waste } \\
\text { Stream }\end{array}$ & Facility & \multicolumn{1}{c}{ Description } \\
\hline ATR & $\begin{array}{l}\text { ATR produces activated metals during reactor core change-out operations, } \\
\text { approximately every } 10 \text { years. These components require an approximate } \\
\text { 8-year decay time and currently are in storage at ATR. This waste was } \\
\text { previously disposed of at RWMC in a cask that is no longer available for use. }\end{array}$ \\
$\begin{array}{c}\text { Activated } \\
\text { Metals }\end{array}$ & NRF & $\begin{array}{l}\text { NRF primarily produces activated metals during routine operations that may } \\
\text { contain other non-activated metal components within the limits of the waste } \\
\text { profile. Currently, the waste is disposed of in RWMC vaults in 55-ton scrap } \\
\text { cask waste containers. }\end{array}$ \\
& MFC & $\begin{array}{l}\text { MFC produces activated metals from ongoing work and from processing of } \\
\text { waste removed from MFC's Radioactive Scrap and Waste Facility. The } \\
\text { majority of this waste contains incidental amounts of debris waste. }\end{array}$ \\
$\begin{array}{c}\text { Ion- } \\
\text { Exchange } \\
\text { Resins }\end{array}$ & ATR & $\begin{array}{l}\text { ATR produces ion-exchange resin waste during routine operations. Currently, } \\
\text { the waste is disposed of offsite in NuPac 14-210L casks. } \\
\text { NRF produces ion-exchange resins during routine operations. Currently, the } \\
\text { waste is disposed of in RWMC vaults in 55-ton scrap cask waste containers. }\end{array}$ \\
\hline
\end{tabular}

The total estimated waste quantities from each of the facilities are presented in Table 3-2. These quantities are based on current waste generation information and represent the anticipated quantity of waste that would be generated at INL facilities beginning in FY 2018 and continuing through at least FY 2037. These values were used to determine the number of vaults that would initially be needed for the facility assuming that the vaults will support the disposal of two containers each. 
Table 3-2. Estimated number of remote-handled low-level waste containers that would require disposal from Fiscal Year 2018 through Fiscal Year 2037 (20-year operation).

\begin{tabular}{|c|c|c|c|c|c|c|}
\hline Facility & $\begin{array}{c}\text { Generation } \\
\text { Cycle }\end{array}$ & Frequency & $\begin{array}{l}\text { Anticipated } \\
\text { Volume of } \\
\text { Waste } \\
\text { Generated per } \\
\text { Frequency } \\
\left(\mathrm{m}^{3}\right) \\
\end{array}$ & $\begin{array}{c}\text { Number of } \\
\text { Containers } \\
\text { Generated } \\
\text { per Year }\end{array}$ & $\begin{array}{c}\text { Total } \\
\text { Number of } \\
\text { Containers }\end{array}$ & $\begin{array}{c}\text { Minimum } \\
\text { Number } \\
\text { of Vaults }\end{array}$ \\
\hline \multicolumn{7}{|c|}{ MFC/ATR Activated Metals Cask System } \\
\hline $\begin{array}{l}\text { MFC } \\
\text { Activated } \\
\text { Metals }\end{array}$ & Continuous & Yearly & 2 & 2 & 40 & 20 \\
\hline $\begin{array}{l}\text { ATR } \\
\text { Activated } \\
\text { Metals }\end{array}$ & Periodic & $\begin{array}{l}\text { Every } \\
10 \text { years }\end{array}$ & 3 & 0.3 & $6^{\mathrm{a}}$ & 3 \\
\hline Total MI & C/ATR Activ & ted Metals & aste Container & posal Capacity & 46 & 23 \\
\hline \multicolumn{7}{|c|}{ 55-Ton Cask System } \\
\hline $\begin{array}{l}\text { NRF } \\
\text { Activated } \\
\text { Metals }\end{array}$ & Continuous & Yearly & 35 & 13 & 260 & 130 \\
\hline \multirow[t]{2}{*}{$\begin{array}{l}\text { NRF } \\
\text { Resins }\end{array}$} & Continuous & Yearly & 8 & 3 & 60 & 30 \\
\hline & \multicolumn{4}{|c|}{ Total 55-Ton Cask Waste Container ${ }^{\mathrm{b}}$ Disposal Capacity } & 320 & 160 \\
\hline \multicolumn{7}{|c|}{$\underline{\text { ATR Resin Cask System (Nu-Pac 14-210L Waste containers) }}$} \\
\hline $\begin{array}{l}\text { ATR } \\
\text { Resins }\end{array}$ & Continuous & Yearly & 36 & 6 & 120 & 60 \\
\hline \multicolumn{5}{|c|}{ Total Nu-Pac Waste container Disposal Capacity } & 120 & 60 \\
\hline \multicolumn{7}{|c|}{$\begin{array}{l}\text { a. Number of containers for ATR activated metals waste is two containers every } 10 \text { years. It is assumed that there will be one } \\
\text { generation cycle of waste ready for disposal when the facility is first opened, with two additional generation cycles being } \\
\text { completed over the } 20 \text {-year operating timeframe, for a total of three generating cycles to be disposed of over the } 20 \text {-year } \\
\text { operating life of the facility. }\end{array}$} \\
\hline
\end{tabular}

Use of the existing RWMC waste disposal system does not generate any secondary waste streams other then very small quantities of used personal protective equipment and miscellaneous materials associated with worker protection that is required for waste placement operations. However, it is possible that an additional wastewater stream could be generated if a subsurface liner approach is selected for implementation based on the liner alternative study. The waste stream would be comprised of any surface water that infiltrates through the disposal area and is collected in the subsurface liner sumps.

Characteristics, quantities, and treatment and disposal processes for this water have not been identified or evaluated at this time. A detailed waste management plan will need to be developed if this type of facility liner is incorporated into the facility design. 


\section{FACILITY DESCRIPTION}

The facility conceptual design (see Appendix A) provides the proposed facility layout for precast concrete disposal vaults that would be used for disposal of remote-handled LLW activated metals and ion-exchange resin waste streams starting in FY 2018. The vault configuration proposed for this facility is similar to the existing vault design and configuration. The facility includes the concrete vaults, vault plugs, access roads, and support infrastructure. Figure 4-1 shows the conceptual layout for the proposed disposal facility with the number of vaults based on the minimum number needed for the waste types and the proposed vault array configuration. Also included in the conceptual design drawings is a conceptual approach for implementing a subsurface liner system. The actual liner approach that will be implemented will be determined based on the results of the liner alternatives study. The technical feasibility and actual structural specifications required for this type of system to be implemented in conjunction with the proposed vault configuration have not yet been developed. Therefore, the majority of the system description presented in this document does not provide the specific design details for the subsurface liner. Other "liner" types that are being considered include waste isolation containers and geochemical adsorption layers that may be used to help capture and reduce the long-term transport time of the disposed radionuclides.

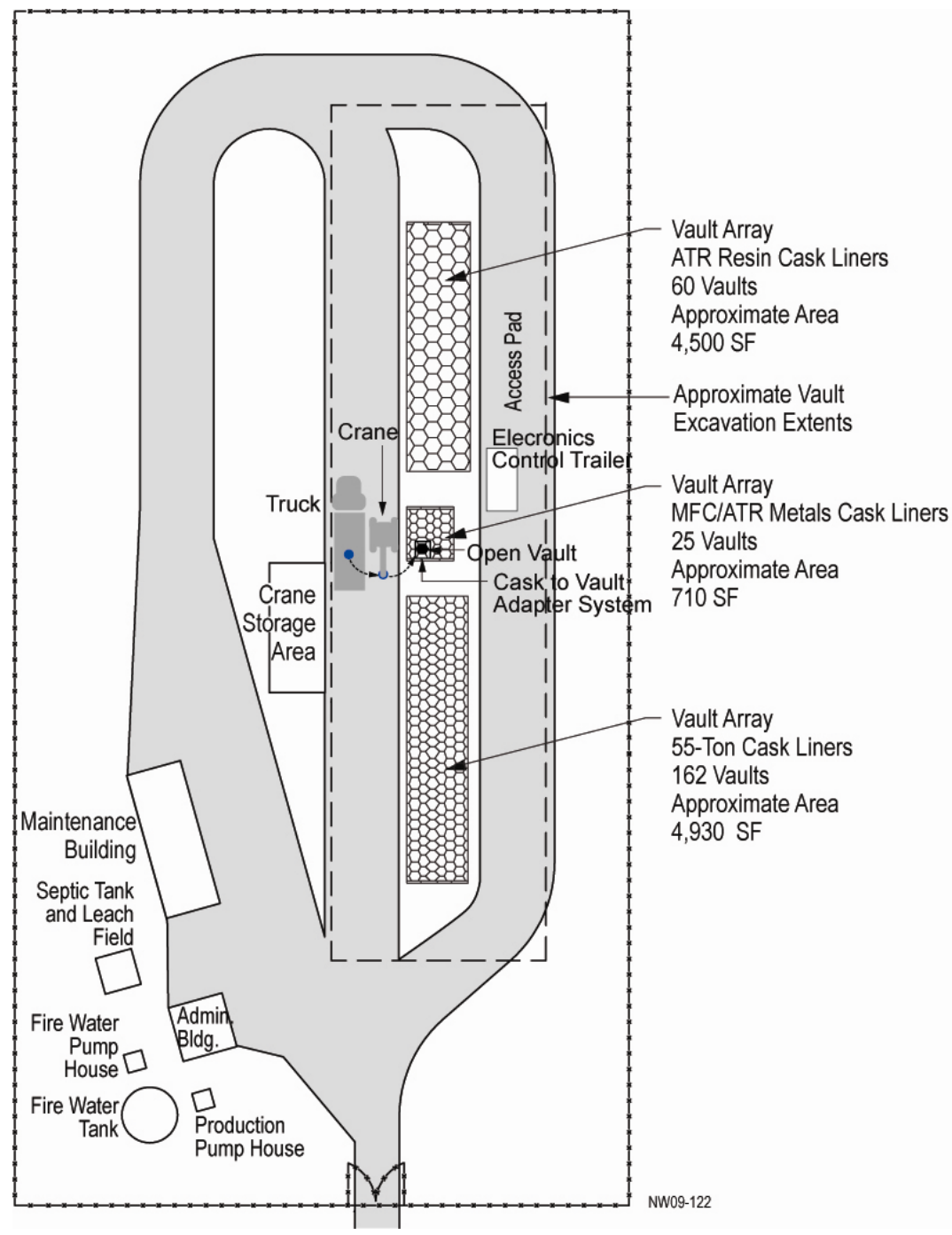

Figure 4-1. Conceptual layout for the proposed Remote-Handled Low-Level Waste Disposal Facility. 
The proposed facility layout is based on the assumption that the facility would be constructed and operated as a stand-alone facility and would provide its own administration buildings and infrastructure to support disposal operations. If a site is selected that is located in the vicinity of an existing facility, then new construction of some of the infrastructure components may not be needed (i.e., the administration building). Conceptual design drawings are provided in Appendix A.

The facility would be laid out in a manner that would allow the trucks entering the disposal facility to have straight in access to the unloading area next to the disposal vaults. The crane and other miscellaneous equipment required for completion of the cask-to-vault transfer operation would be staged before arrival of the waste containers. Figure 4-2 illustrates the facility configuration with a photo showing the equipment currently staged for operation at the RWMC facility. The proposed facility would use these same methods and will set up the necessary equipment in a similar configuration.

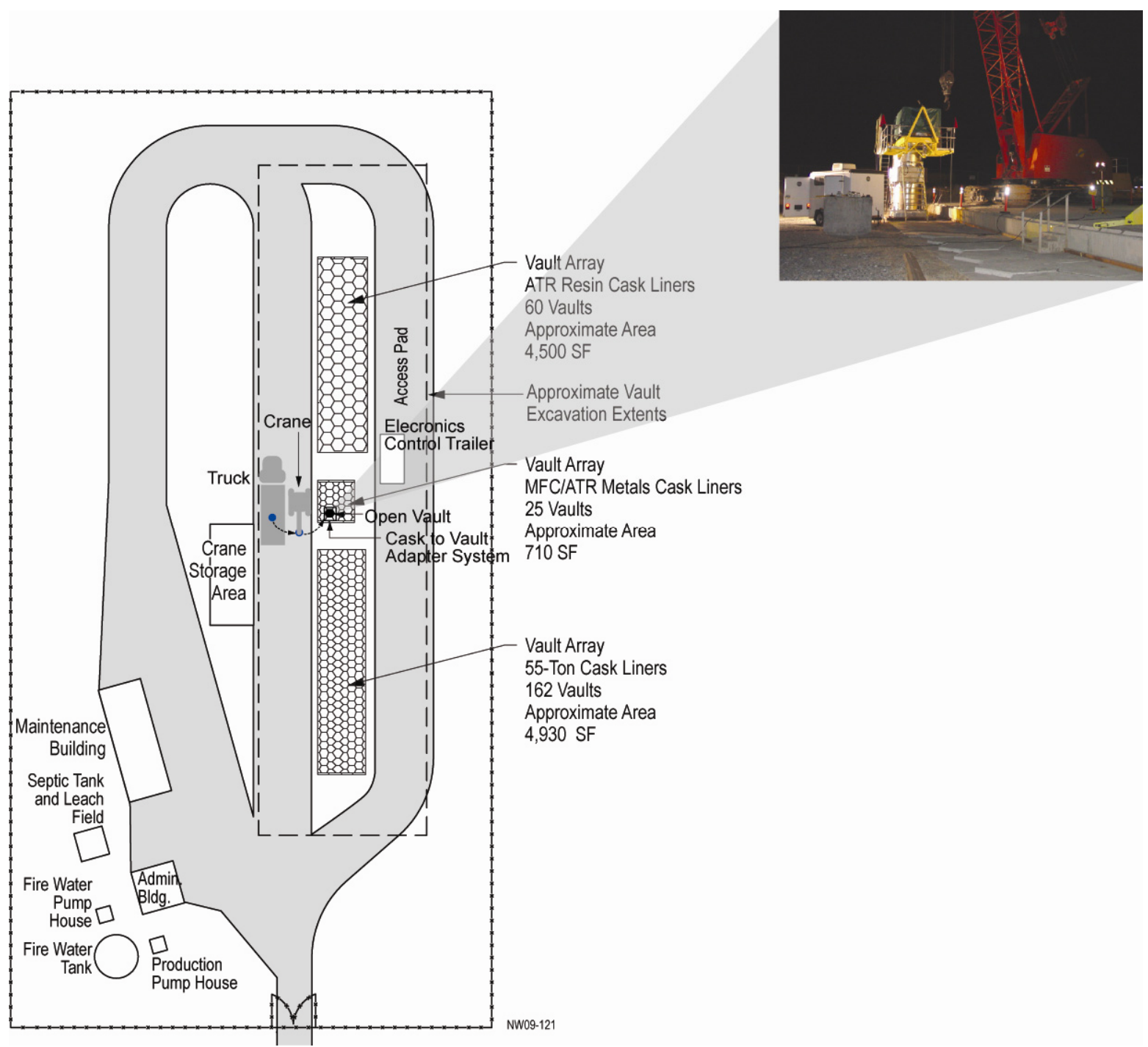

Figure 4-2. Proposed Remote-Handled Low-Level Waste Facility operational configuration.

The total number of vaults that would be constructed will depend on the depth of surficial sediment at the specific site selected for the facility and the results of the Performance Assessment and Composite Analysis. The general layout in the conceptual design shows the proposed extent of the vaults as 
determined using a vault depth that can accommodate the disposal of two waste containers per vault. In this configuration, a total of approximately 162 vaults would be designed for NRF waste; 25 vaults would be designed for the activated metals waste generated at MFC and ATR; and 60 vaults would be designed for ATR ion-exchange resins. If the selected site has sufficient surficial sediment, then the vaults possibly could be designed to dispose of more than two waste containers; however, this most likely would only apply to the ion-exchange resin vaults.

\subsection{Facility Boundaries}

For the conceptual design, it is assumed that the proposed facility would be a stand-alone facility that does not use the services of any existing INL facilities. The facility would be sited within INL boundaries and be operated by the INL site operating contractor. Perimeter fencing would be constructed to provide protection from human and animal intrusions and to allow for proper access control.

An overall facility area for siting purposes is based on the required site-specific components and is estimated to be between 4 to 6 acres (1.6 to $2.4 \mathrm{ha}$ ). The total number of vaults that are proposed may change depending on the final selection of waste containers to be used for the lifespan of the facility.

\subsection{Coordination of Activities between Facilities/Organizations}

At the present time, generating facilities are controlled by different operating contractors. ATR and MFC are under the control of the INL contractor. NRF operations are controlled by a separate contractor, who is under contract directly with the Office of Naval Reactors. Thus, close coordination between these entities will be required to ensure that all the tasks required for waste disposal are identified and assigned to the proper organization (see Section 4.4 for details of commitments placed on the generator organizations). It is imperative that appropriate coordination and planning occur to support obtaining funding that will allow the organizations to complete their respective tasks before the planned start date of FY 2018.

Project personnel will be assigned from each of the organizations and will be identified in the project execution plan.

\subsection{Facility Conceptual Design Assumptions}

The following assumptions have been used in development of the proposed conceptual design:

- The new disposal facility would be a stand-alone facility and would not be located adjacent to other INL facilities that may be able to provide some operational support.

- $\quad$ The CVAS currently in use at RWMC for the NRF scrap cask would continue to be used for placement of the waste containers at the proposed facility.

- Waste containers currently in use at NRF would continue to be used for waste disposal, and a portion of the vaults at the future remote-handled LLW disposal facility will be sized to receive these containers. The remainder of the vaults will be sized to accommodate containers for the ATR ion-exchange resins and containers used for the activated metals generated at MFC and ATR. 
- New cask-handling equipment would be procured/designed for waste containers anticipated for remote-handled LLW activated metals generated at MFC and ATR. It is assumed that a commercially available cask and waste container system will be used for shipment of the activated metal waste. It is assumed that the activated metals waste containers will fit within a commercial cask, which has a cylindrical configuration with a $3-\mathrm{ft}(1-\mathrm{m})$ diameter and 9.3-ft $(2.8-\mathrm{m})$ high maximum dimension. This dimension will be used to size the vaults that will be used for disposal of activated metal waste generated at MFC and ATR. Any deviations from this assumption will be defined as the project matures. Such changes are not anticipated to change the basic design of the facility, but rather the number of vaults of a specific configuration/size that would be needed.

- $\quad$ The actual containers used for packaging the remote-handled LLW for transport using the new cask will be procured by the individual operating/generating facilities. Any ancillary equipment specifically required to load the generator selected waste container into the new shipping cask, including typical hoisting and rigging components, will be provided by the project.

- $\quad$ Existing 75-in. (190-cm) diameter waste containers will be used for packaging and disposal of ATR resins. These containers will be transported within the NuPac 14-210L cask that currently is being used. Typical hoisting and rigging components and any ancillary equipment specific to the container design that is needed to unload the container from the shipping cask and to place the containers into the disposal vaults will be provided by the project.

- $\quad$ The vaults will be constructed using standard precast concrete pipe sections.

- $\quad$ The existing crane located at RWMC, as part of the NRF 55-ton cask system, would be available for use, in good condition, and would be transferred to the new disposal facility to support future operations.

\subsection{Facility Components}

The following major components are included with the facility:

- Vaults

- $\quad$ Vault plugs

- Crane

- $\quad$ CVAS

- $\quad$ Facility liner

- $\quad$ Staging and storage area

- $\quad$ Administration and other supporting infrastructure

- $\quad$ Final closure cover.

The following subsections provide a description of each of these components. 


\subsubsection{Vaults}

The vaults would be aligned vertically to allow multiple remote-handled LLW containers (one on top of the other) to be inserted in a vertical orientation. The 55-ton scrap cask vaults would be designed to interface with the existing CVAS and 55-ton scrap cask. All handling equipment, consistent with the current configuration and practices at RWMC, would be used. The 55-ton cask waste containers are approximately 47 in. $(119 \mathrm{~cm})$ in diameter and $104 \mathrm{in.}(264 \mathrm{~cm})$ high.

It is assumed that the waste generated at MFC and ATR would be transported in a commercially available cask with internal dimensions to accommodate waste containers that are approximately 36 in. $(91 \mathrm{~cm})$ in diameter and $111 \mathrm{in} .(282 \mathrm{~cm})$ high. The vaults would be designed, procured, and fabricated to interface with commercially available cask waste containers.

It is assumed that the remote-handled LLW ion-exchange resins generated at ATR would continue to be transported in the NuPac 14-210L cask. The ATR resin containers are approximately $75 \mathrm{in}$. $(190 \mathrm{~cm})$ in diameter and 75 in. $(190 \mathrm{~cm})$ high. The ATR resin vaults would be designed, procured, and fabricated to interface with the cask waste containers.

The MFC and ATR activated metals vaults and the ATR resins vaults would be configured similar to the 55-ton scrap cask vaults in regard to access and surface configuration.

Figure 4-3 provides a cross section of the proposed vault design. Each 55-ton scrap cask vault and MFC and ATR activated metals vault would be comprised of 10-ft (3-m) sections of precast concrete pipe, stacked on end, for a total interior height of either 20 or $30 \mathrm{ft}(6$ or $9 \mathrm{~m})$. Each ATR resins vault would be comprised of 8-ft $(2.4-\mathrm{m})$ sections of precast concrete pipe, stacked on end for a total interior height of either 16 or $24 \mathrm{ft}$ ( 4.9 or $7.3 \mathrm{~m}$ ). Each section would allow the space needed to place one container, while including enough additional space to accommodate any special protection plates or other components that may be needed for specific disposal operations (e.g., 6-in. [15-cm] steel spacers). The 55 -ton scrap cask vaults would have an inside diameter of 54 in. $(137 \mathrm{~cm})$ and an outside diameter of 65 in. $(165 \mathrm{~cm})$. The MFC and ATR activated metals vaults would have an inside diameter of 48 in. $(122 \mathrm{~cm})$ and an outside diameter of $58 \mathrm{in} .(147 \mathrm{~cm})$. ATR resins vaults would have an inside diameter of 84 in. $(213 \mathrm{~cm})$ and an outside diameter of 101.5 in. $(258 \mathrm{~cm})$. All vaults would be supported by a reinforced concrete base at least $12 \mathrm{in} .(30 \mathrm{~cm})$ thick. The vaults would be vertically arranged, side-by-side, in an array with a removable precast concrete shield plug.

The concrete base would be precast onto the end of the first section of concrete pipe. Each base section would be constructed with drain holes to prevent the accumulation of moisture within the vaults. The base sections would be set level on the bottom surface of the excavation, after which the additional pipe sections would be placed vertically on top of the base sections. Sand would be placed between the vaults as the sections are being installed to provide the stability needed to keep the vaults in place.

To support loading operations, the top surface of the vaults would be designed to support the maximum applied load. The maximum applied load will be a result of either the combined weight of the CVAS, casks, and waste container, or it will result from the combined weight of the vault plug, crane (with load), and 2-ft (0.6-m) soil cover. These loads will vary with the different vault sizes. However, the greatest load will be used for the vault design. It should be noted that if it becomes necessary to move the crane onto the vault array to facilitate placement, the soil cover and the length of the crane tracks will allow the weight of the crane and its load to be distributed across multiple vaults. 


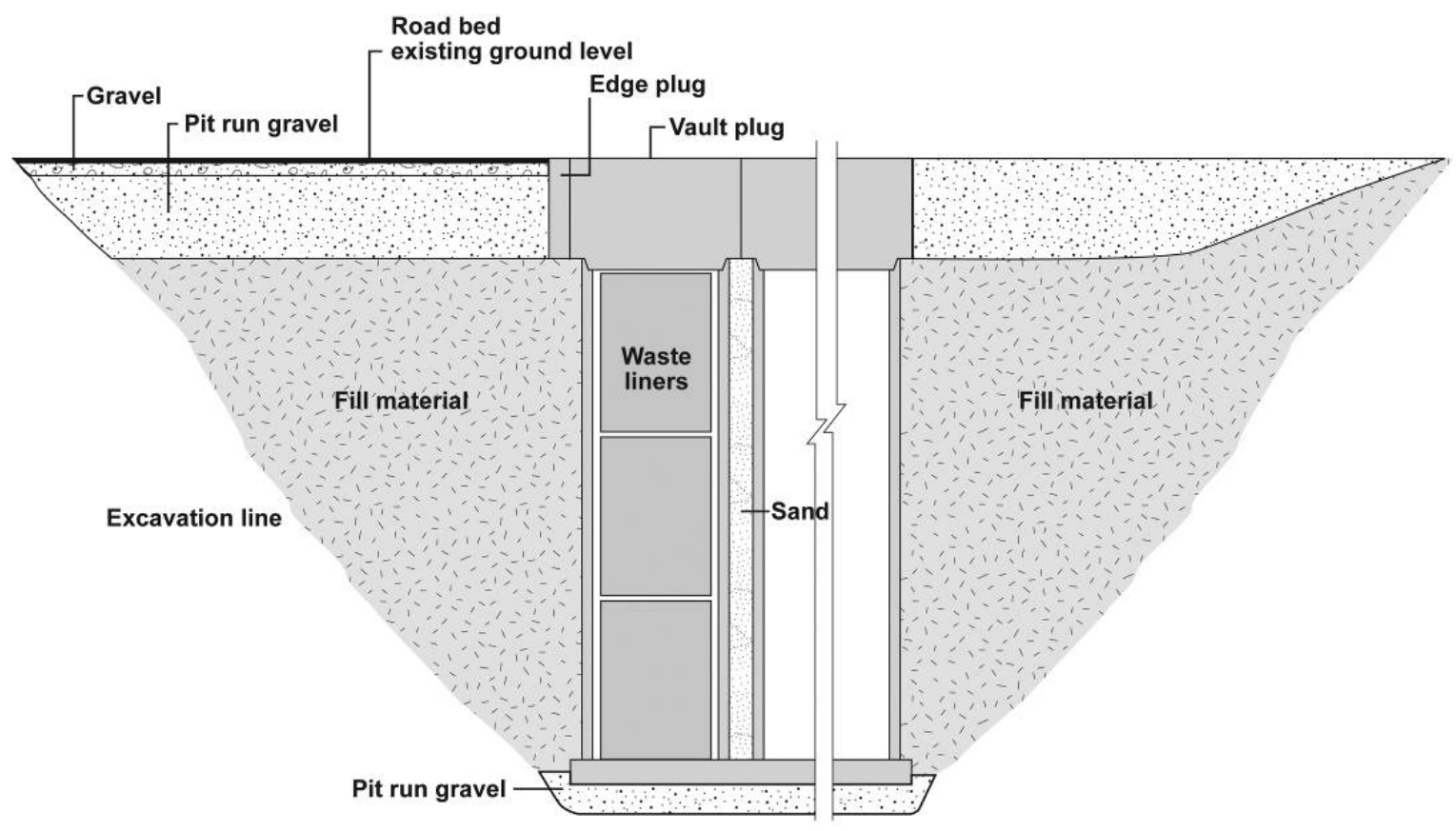

Figure 4-3. Vault profile.

Any additional container systems that need to be incorporated into the facility would need to be designed around the physical and operational parameters of the vaults described in this section.

\subsubsection{Vault Plug}

A removable concrete plug would be set in place on top of each stacked cylinder vault. The plug will serve as a radiation shield for placed waste and also will act as a water barrier to prevent surface water from entering the concrete vaults. All plugs would be kept in place before and after the vaults are loaded. The top of the plugs will provide a working surface for all equipment needed to support the waste disposal operations. The plugs would be configured in a hexagonal shape that covers each of the cylindrical vaults.

The vault plug thickness would be based on using a standard radioactive shielding halving thickness for concrete of $2.4 \mathrm{in}$. $(6 \mathrm{~cm})$ and the need to reduce a radiation field level of up to $30,000 \mathrm{R} /$ hour to less than $1 \mathrm{mR} /$ hour. Based on these values, the vault plugs will be $5 \mathrm{ft}(1.5 \mathrm{~m})$ thick.

\subsubsection{Crane}

The Manitowoc 3900W, Series 2 crane currently in use at RWMC (Figure 4-4) would be disassembled, refurbished, and transported to the proposed disposal facility. This crane is a mobile, two-track crane with a total weight of $262,225 \mathrm{lb}(118,943 \mathrm{~kg})$ and a lifting capacity of approximately 140 tons $(127,000 \mathrm{~kg})$. If it is determined that the existing crane would not be available, a new crane with similar lifting capacity would need to be procured for the facility.

It is assumed that current lifting requirements associated with the 55-ton cask waste container disposal operations are conservative as related to the lifting requirements that may be required for the new activated metals cask operations. 


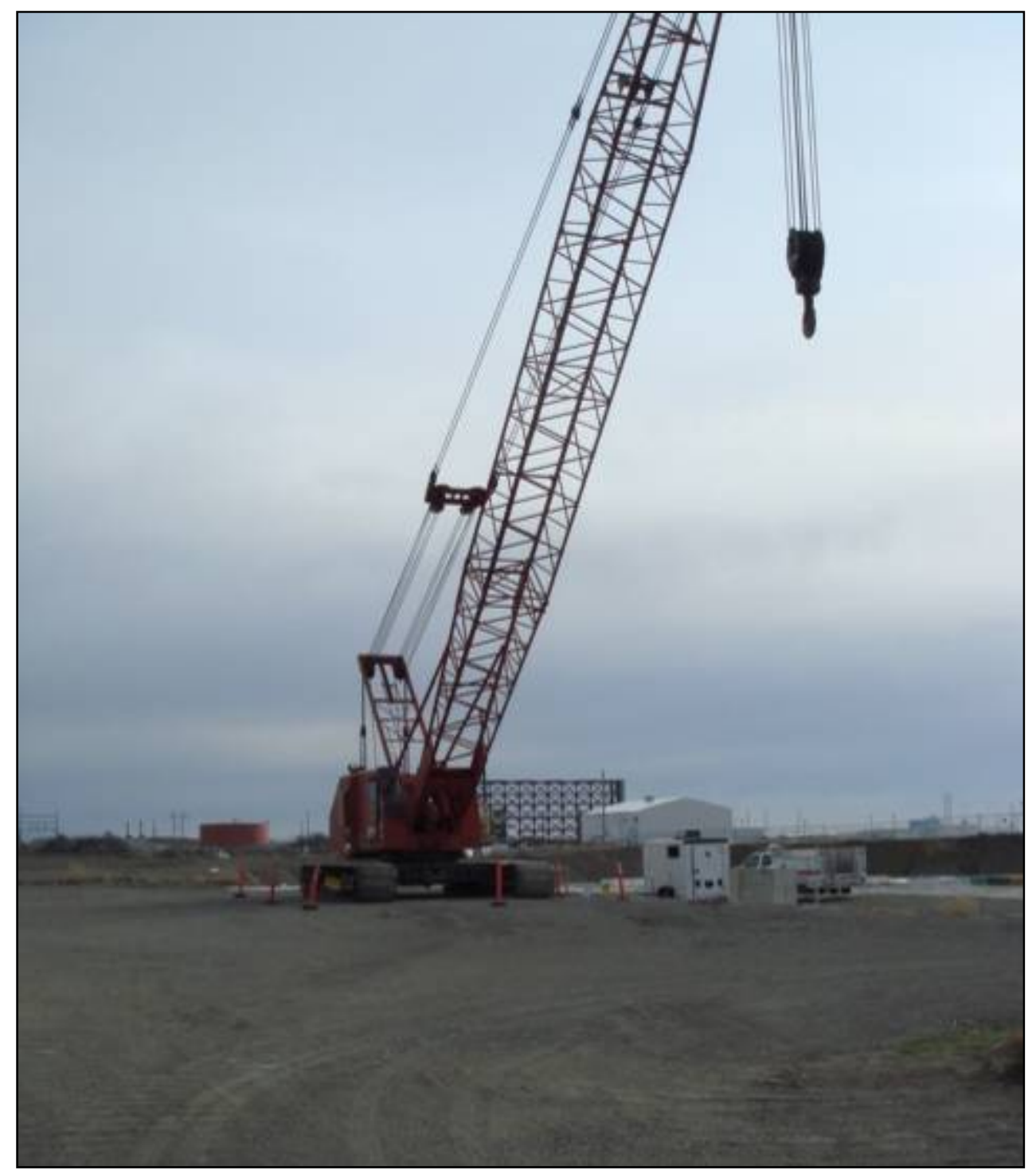

Figure 4-4. Manitowoc 3900W, Series 2 crane.

\subsubsection{Cask-to-Vault Adapting Structure}

The CVAS currently located at RWMC would be transferred to the proposed disposal facility. All supporting equipment and components (i.e., the hoisting platform, lifting rigging, and control trailer) also would be made available for use.

Container handing equipment would be required for the ATR resins container and MFC and ATR activated metals container systems. The systems will be required to provide accurate positioning of the waste containers over the vaults and provide container placement into the vaults. It is assumed that typical hoisting and rigging components may be used to perform these functions. These types of components will be provided to the disposal facility as part of this project. If there are any specialized container handling mechanisms developed by the generating facilities for use with their specific containers, these components would be provided by the generating facility (if they are needed for final waste container placement into the vaults for disposal). 
Figure 4-5 shows the general setup that would be used for the NRF CVAS and 55-ton scrap cask. It is assumed that equipment needed for unloading the MFC and ATR activated metals shipping casks and the ATR ion-exchange shipping casks would use routine hoisting and rigging methods associated with top loading, shielded transfers methods, and provide the necessary radiation protection needed to allow opening and closing of the cask and disposal vaults.

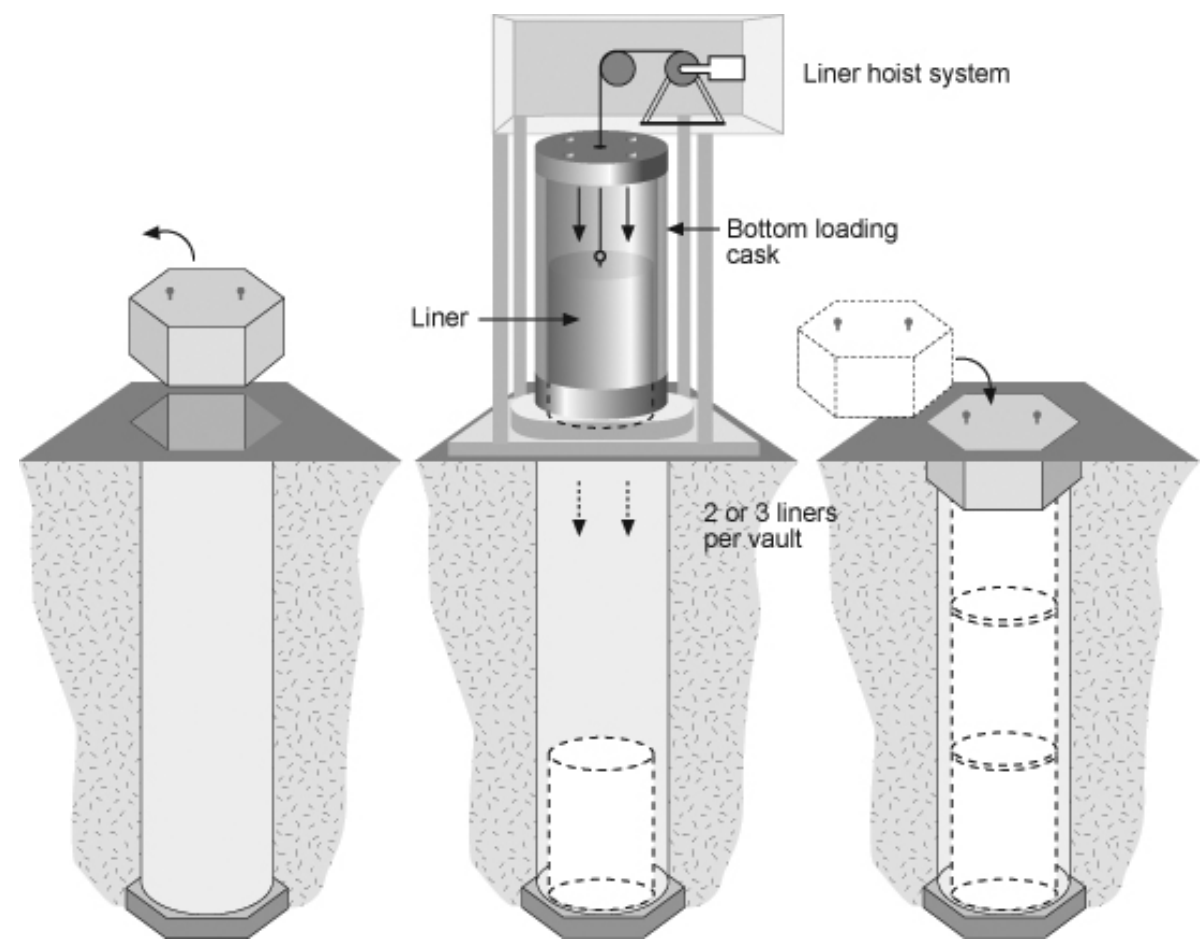

Figure 4-5. Vault disposal process with the cask-to-vault adapting structure components.

\subsubsection{Facility Liner}

The facility liner shown in the conceptual drawings is a double-lined layer system using subsurface barriers made of either clay or a geosynthetic clay liner that will be placed below the disposal vaults with the sides of the liner brought up to surface level. This liner will capture all water that infiltrates into the lined area. At this time, the liner has been included in the conceptual layout as a worse case alternative for providing a facility liner. The actual liner incorporated into the design will be determined based on the results of the liner alternative study.

This liner system would be configured similar to a standard hazardous waste landfill system, with water collection monitoring and extract systems. The following items are included:

- A double-lined layer system located below the concrete vault area. The perimeter of the liners will extend upward to the surface.

- A subsurface collection sump will be located on one end of the disposal facility with the subsurface liners sloped toward the sump location. 
- The extent of excavation at the surface is $570 \times 242 \mathrm{ft}\left(137,940 \mathrm{ft}^{2}\right)$ with a slope of 3:1 on the sides of the liner up to the surface. The subsurface layers will consist of the following (Figure 4-6):

- $\quad$ 2-ft leveling layer (gravel)

- $\quad$ Geocomposite layer to be a barrier between the gravel and the liner

- $\quad$ High-density polyethylene geomembrane liner

- Geosynthetic clay liner

- Geocomposite layer

- $\quad$ High-density polyethylene geomembrane liner

- $\quad 3$-ft clay liner

- $\quad$ 1-ft leveling layer (gravel).

- Two water detection and monitoring systems will be located within the subsurface sump area. The system will include perforated piping to allow any water that gets to the sump to be collected in the pipe. A liquid detection transducer will be placed within the collection pipe to detect when water is present and to provide water level measurements.

- $\quad$ Two water removal pumps will be installed within the collection pipe. One pump will be located on the top of each liner within the sump.

- A water-handling and processing enclosure will be provided with a surge tank, discharge pump, and media filter. The water-handling enclosure will be a $10 \times 20 \mathrm{ft}$ building that will house an elevated 220-gal holding tank, a 2-horsepower transfer pump, and a 500-lb granular activated carbon filter. An alarm and pump control panel will be placed in the enclosure with the capability for remote monitoring via telephone line.

- An evaporation pond will be $80 \times 120 \mathrm{ft}\left(9,600 \mathrm{ft}^{2}\right)$ with a single layer, high-density polyethylene/ geosynthetic clay liner. The pond will have a berm that is raised $2 \mathrm{ft}$ above the ground surface and be $4 \mathrm{ft}$ deep.

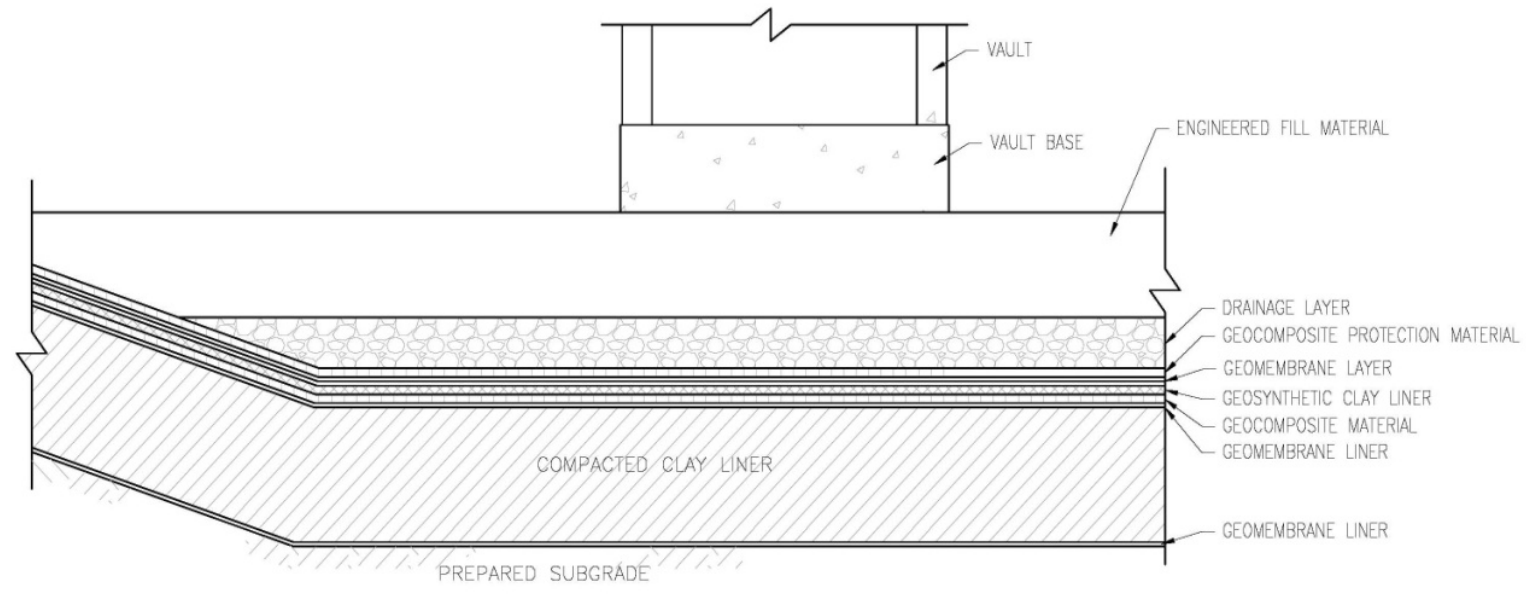

Figure 4-6. Facility liner subsurface profile. 


\subsubsection{Staging and Storage Areas}

Staging and storage pads would be provided within the facility for the operating equipment. These pads would be constructed using pit run gravel with a crushed gravel top surface. Areas would be provided for storage of the crane; the CVAS components, including the working platform; the bearing pad; the shield plug; and the electrical control trailer.

\subsubsection{Administration and Other Supporting Infrastructure}

Additional support and administrative structures and services are included in the proposed conceptual design as follows:

- Administration building:

- Office space

- $\quad$ Records storage

- Equipment storage

- Electrical distribution

- Maintenance enclosure:

- Equipment maintenance

- $\quad$ Temporary cask holding area

- Equipment decontamination

- $\quad$ Equipment storage

- $\quad$ Access roads:

- Vehicle access within facility and around vaults

- $\quad$ Facility road that provides access to/from major road

- $\quad$ Electrical power infrastructure

- $\quad$ Fixed communications system

- $\quad$ Potable water system, if needed

- $\quad$ Sanitary sewer system, if needed

- $\quad$ Fire detection/protection system

- $\quad$ Perimeter fencing

- $\quad$ Video monitoring. 
If the facility is located adjacent to an existing facility, some of the services described in this section could be provided by that facility.

The primary utility that would be needed to operate the proposed facility is electrical power. At the present time, a portable generator is used to power all unloading and waste placement operations at RWMC. Operations at the proposed facility would use power provided by electrical pedestals that will be located near the disposal vaults. In addition, power would be needed for support infrastructure that is currently provided by RWMC facilities. Other power needs include the administrative building, equipment maintenance and staging, and site control and monitoring capabilities. Location near an existing power source is a benefit but not necessarily a requirement for facility siting. Other utilities, such as fire detection and protection, telecommunication, sewer, and water, also are included in the proposed conceptual design.

During final design activities, each of the occupied buildings will be designed to incorporate the applicable sustainable building and energy conservation requirements outlined in DOE Order 430.2B, "Renewable Energy and Transportation Management," and DOE Order 413.3B. Appendix B provides an initial sustainability design report that identifies the Leadership in Energy and Environmental Design (LEED) certification criteria that may be applicable to design and construction of the two associated buildings. The LEED criteria are used to address the high-sustainable building principles that can be incorporated into the project.

Road access that would allow transport of the loaded cask vehicles must be provided. Figure 4-7 shows the 55-ton cask transport vehicle. A haul route will be identified or designed that would provide for passage of anticipated cask transport loads without damaging any existing infrastructure. The truck's turning radius, maneuverability, unloading positioning, and drive slopes also would be taken into consideration when determining the haul route alignment. The 6-acre (2.4-ha) site area is assumed to be sufficient to design appropriate road access for transport loads and vehicles within the disposal facility.

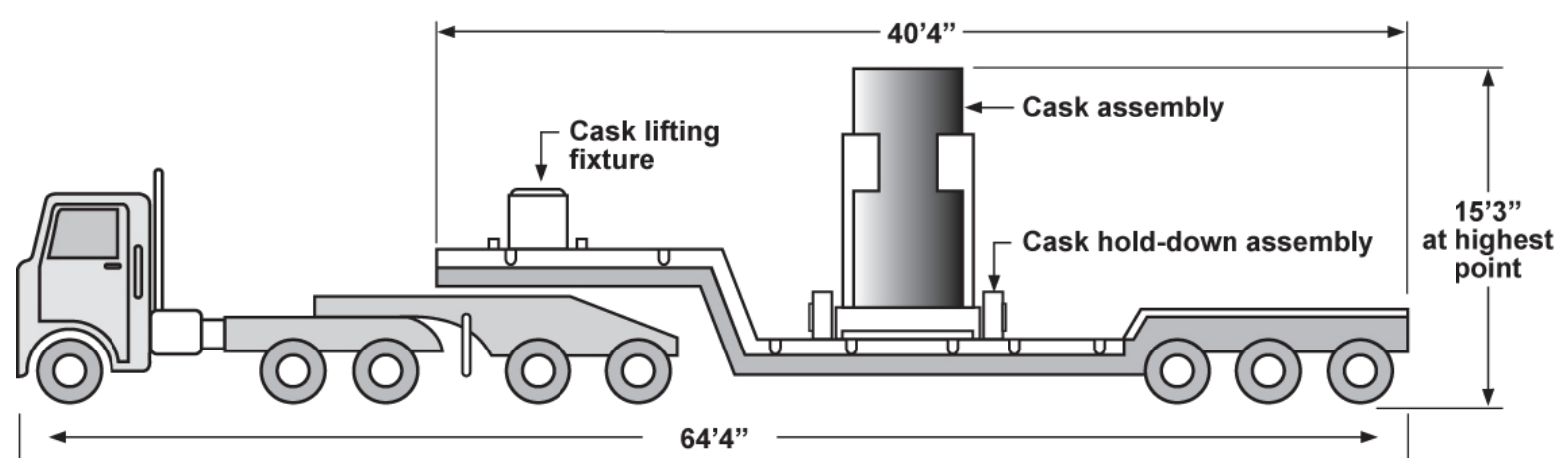

Figure 4-7. A 55-ton cask transport vehicle.

\subsubsection{Final Closure Cover}

At completion of the operational life of the disposal facility, a long-term protective cover will be placed over the waste disposal vaults. This final closure cover will be an evapotranspiration barrier that will cover the entire disposal facility (Figure 4-8) and protect waste material from contact with infiltration water. This barrier will include a vegetated soil layer, an underlying coarse rock layer, a low permeability layer, and grading fill material. The barrier will be configured to divert all surface water away from the storage vaults and extend beyond the boundary of the facility. The total thickness of each layer, exact dimensions, and other specifications will be determined prior to facility closure and be based on the final size and configuration of the facility. The barrier also will incorporate criteria identified in the applicable facility performance assessment. 


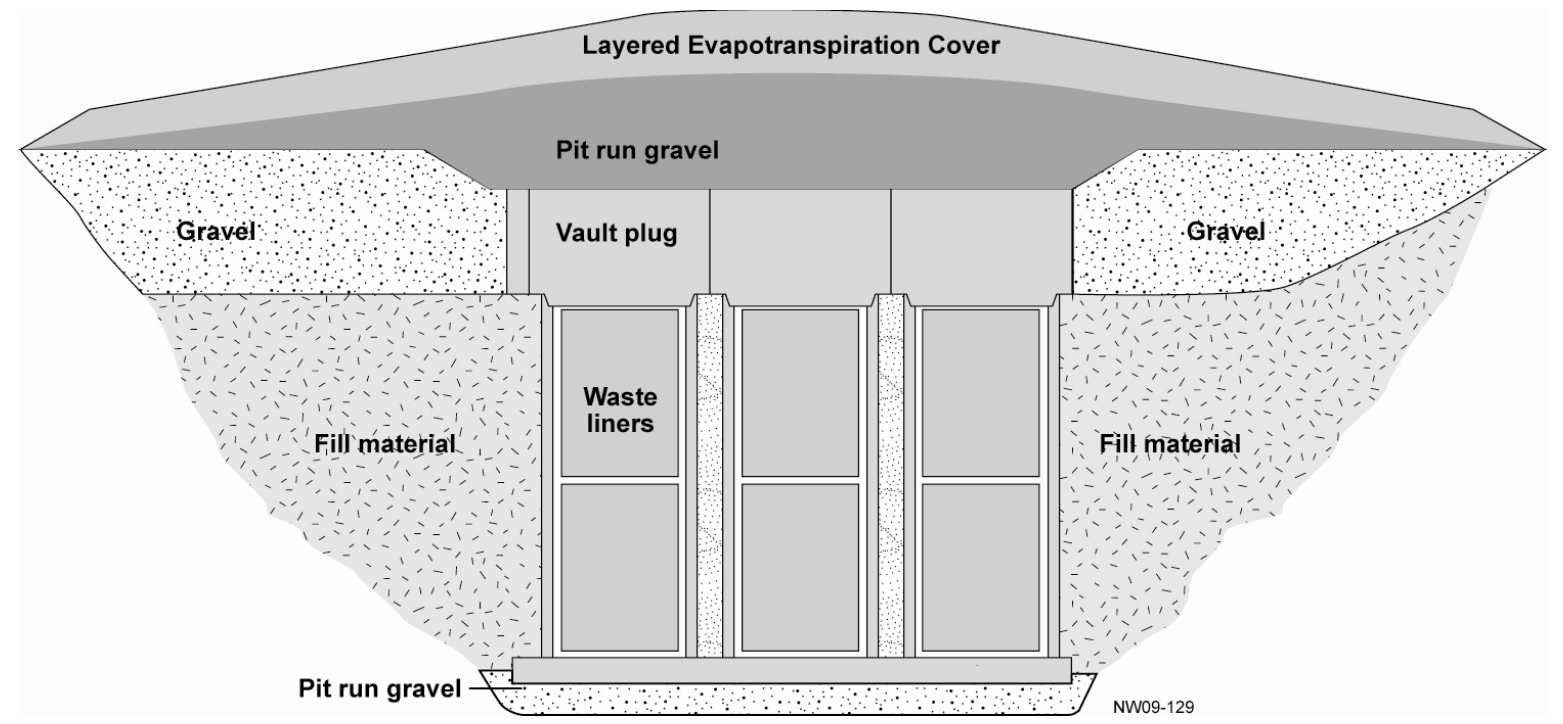

Figure 4-8. Final closure cover.

\subsection{Design Approach}

The design approach for this project includes utilization of a design-build approach for the proposed disposal facility. The design and construction/fabrication will be contracted to an appropriate vendor. The conceptual design and facility performance specification will be used to identify all applicable nuclear safety, security, and radiological performance requirements for the project prior to start of the final design and construction activities.

All components within the facility will be designed to the INL Architectural Engineering Standards (STD-139) and other codes and standards listed in Section 2.9. All components are standard commercial/industrial items that will be designed and fabricated to standard industrial practices.

A review of the conceptual design was conducted by external subject-matter experts. The comments and resolutions resulting from that review are included in Appendix C.

\subsubsection{Civil}

Total interior vault depth would be approximately $20 \mathrm{ft}(6 \mathrm{~m})$ for vaults accepting two containers. Excavation depth that would be required for this configuration is approximately $29 \mathrm{ft}(8.8 \mathrm{~m})$. The required excavation would be completed in accordance with applicable DOE and Occupational Safety and Health Administration (29 CFR 1926) requirements. All earthwork, including excavation, backfill, rock removal, compaction, and final grading, would comply with INL Engineering Standards (STD-139-1011).

Structural design of the vault system would be in accordance with criteria specified in the INL Engineering Standards (STD-139-1012) and DOE-STD-1020-02, "Natural Phenomena Hazards Design and Evaluation Criteria for Department of Energy Facilities." The design life of facility components would be 50 years.

Structural loading evaluations have been completed and show acceptable structure sizing for the vault configuration as shown without the subsurface liner in place. Further structural analysis is required to ensure this vault configuration can be used when placing the vaults above the engineered subsurface liners and associated backfill materials. 


\subsubsection{Architectural}

Two support structures would be required for the facility in addition to the disposal vaults: (1) an administrative building and (2) a maintenance building. The administration building would include office space, records/small equipment storage room, and an electrical/storage area with overhead door. The building would be approximately $30 \mathrm{ft} \times 30 \mathrm{ft}(9 \mathrm{~m} \times 9 \mathrm{~m})$ with concrete foundations and slab on grade. The expected occupancy of the building would be 5 to 10 people for up to 16 days per month. It is expected to be unoccupied the balance of the time.

The maintenance building would be a high, open bay building that will be used for various maintenance activities and equipment storage related to the CVAS, cask, and transport system. Two overhead doors would be provided that allow the transport vehicle to pass through the building, if needed. This building would be a $30-\mathrm{ft} \times 80-\mathrm{ft}(9-\mathrm{m} \times 18-\mathrm{m})$ pre-engineered metal building with concrete foundations and slab on grade. This building also would provide space for extra shielding components in case they are needed to support special operations.

Both buildings would be designed and inspected in accordance with International Building Code (IBC) standards and be designed in accordance with the applicable sustainable building and energy conservation requirements.

\subsubsection{Structural}

The proposed remote-handled LLW disposal facility has a preliminary facility Seismic Design Category of 1, based on the applicable facility hazards and in accordance with Section 4 of ANSI/ANS-2.26, "Categorization of Nuclear Facility Structures, Systems, and Components for Seismic Design." The applicable facility hazards are discussed in detail in Section 7. As stated in the standard, no limit state identification is required for Seismic Design Category 1 systems and the seismic evaluation on the facility will be performed in accordance with the IBC (2009).

This determination will be further evaluated as part of development of the preliminary documented safety analysis and any changes will be incorporated into the project TFR and performance specification. The concrete vaults and support building would be evaluated using the IBC (2009) guidance for the associated type of facilities. The administrative buildings would be planned to have an Occupancy Category of II and be configured as slab on grade buildings.

Foundations for all buildings will require a minimum frost depth of $5 \mathrm{ft}(1.5 \mathrm{~m})$. Excavation for the footings should not encounter rock formations because the facility is to be sited in an area with significant surface soil depth.

Structural analysis for the vault footings has been completed for six possible vault configurations (i.e., NRF vaults with two or three containers, MFC and ATR activated metals vaults with two or three containers, and ATR resin vaults with two or three containers). Loads include the precast concrete pipe sections, vault plug, waste containers, CVAS components, cask, and mobile crane. The footing dimensions will need to be verified for specific configurations used during the final design activities. These structural analyses did not include the presence of a subsurface engineered liner placed below the vault structures. Additional analysis will be required if the subsurface liner alternative is selected.

As part of the final design, the remote-handled LLW vault design and construction scope of work will require a comprehensive seismic analysis to be completed in accordance with the IBC practices for a Group 1 facility. 


\subsubsection{Mechanical}

There are no safety-significant or key mechanical systems anticipated to be involved in development of this proposed facility. The primary mechanical system is related to operation of the hoisting system associated with the working platform used to lower the waste containers into the vaults. The current system is owned by the Office of Naval Reactors and is planned to be transferred to the proposed disposal facility for use in waste placement operations. This system has been used for many years and has been proven successful in operation.

Development of the cask transfer system will need to ensure that all applicable mechanical systems are designed using the appropriate protocols; however, these design activities are the responsibility of the generating facilities and are not part of the facility design and construction activities.

Typical heating and cooling equipment would be needed for the administration and maintenance buildings. Applicable mechanical components would include commercially available heating and cooling units, as needed, for the relatively small interior spaces.

Water, sewer, and fire protection services would also be planned for the facility.

\subsubsection{Fire Protection}

A fire safety analysis will be performed as part of the final design. Fire detection and suppression systems would be installed based on the results of the fire-safety analysis. Fire protection for the administration and maintenance buildings will adhere to requirements of the Life-Safety Code (NFPA 101) and the International Fire Code 2003 (as adopted by the state of Idaho in the Idaho Administrative Procedures Act [IDAPA] 18, Title 01, Chapter 50). The facility will normally be considered as an unoccupied storage facility.

\subsubsection{Electrical}

Electrical power would be provided to the facility. Primary power usage would be for the CVAS unloading components and control trailer and the normal building power distribution for office and lighting. Perimeter and vault area lighting also would be provided.

Electrical power used in the current (i.e., RWMC) waste placement operation is provided using a portable electrical generator. Instead of using the generator, electrical pedestals will be provided near the disposal vaults. Extension cords will be supplied to connect to the working platform and electronic control trailer. Building and vault area lighting will be designed to ensure safe operations within the facility and during waste placement operations.

Power would be brought into the facility connecting to existing $13.8-\mathrm{kV}$ electrical distribution lines. New pole-mounted, 13.8-kV/480 VAC three-phase transformers would be required at the facility. The 480-V power would be brought into an electrical distribution room located within the administration building. Power to all areas of the facility would be routed from this location.

The anticipated electrical load list, containing electrical load data estimates for the various processes and building services, is provided in Table 4-1.

Design of electrical systems will be governed by the National Electrical Code (NFPA 70), IEEE-STD-141, IEEE-STD-242, and DOE-HDBK-1092. Power feeds to the disposal vault area would be routed via underground, concrete-encased duct banks. The total electrical demand for the proposed facility is estimated at approximately $98 \mathrm{kVA}$. 
Table 4-1. Remote-Handled Low-Level Waste Disposal Facility anticipated electrical load summary.

\begin{tabular}{lcc} 
Administration Building & Volts & Amps \\
\hline Receptacles & 120 & 60 \\
Lighting & 120 & 100 \\
Heating and cooling & 208 & 100 \\
Access gate & 480 & 20 \\
\hline Disposal Vault Operations & & \\
\hline Receptacles/pedestals & 480 & 50 \\
\hline Maintenance Building & & \\
Receptacles & 120 & 80 \\
Lighting & 480 & 50 \\
Heating and cooling & 120 & 140 \\
Overhead doors & 208 & 255 \\
\hline Perimeter and Area Lighting & 120 & 40 \\
\hline
\end{tabular}

\subsubsection{Radiological Control}

Waste disposal operations would be conducted in accordance with established radiation protection standards, limits, and program requirements for protecting individuals and the environment from ionizing radiation. These limits are established in performance objectives for LLW disposal facilities, as found in DOE Order 435.1-1. Worker protection would be provided in accordance with 10 CFR 835 and the site-specific administration control levels. The facility configuration would be designed to reduce potential worker exposure fields to less than $1 \mathrm{mR} /$ hour when all components are in position on top of the disposal vaults and no waste transfer activities are in progress. Vault plugs (5-ft [1.5-m] thick) would be used to provide the shielding required for each of the disposal vaults. Worker protection for operators present during waste transfer activities would be addressed in specific operating procedures. 


\section{PROJECT COST}

\subsection{Summary of Cost Estimate}

Life-cycle costs associated with development of the proposed remote-handled LLW disposal facility include design and construction of the infrastructure, design and construction of vaults, procurement of a cask for onsite transport of INL-generated remote-handled LLW, development of the disposal authorization and safety basis documentation, project management, operations and maintenance, and facility closure. Two estimates were prepared for the project. The first estimate includes costs for design and construction of the proposed remote-handled LLW disposal facility based on the design presented in this conceptual design report. The second estimate addresses operations, maintenance, and disposal facility closure following the useful life of the proposed facility. Operations and maintenance costs were based on cost information for the operation and maintenance of the remote-handled LLW disposal facility in the SDA and include facility monitoring costs. Closure costs include design and construction of a final cover for the facility and decontamination and decommissioning of all support structures. All costs were developed using FY 2010 dollars and were escalated in accordance with DOE guidance. The project estimates also include management reserve and DOE-held contingency that is assigned based on risks and uncertainty associated with individual cost elements.

\subsection{Total Project Cost Range}

Total project cost (TPC) includes all costs associated with the project, including contingency, to the point the proposed disposal facility is turned over for routine operations. TPC includes all capital costs and operating costs associated with the project. The TPC is composed of total estimated cost (TEC) and other project cost (OPC). The TPC range for the design, siting, construction, and turnover to operations of a new INL remote-handled LLW disposal facility is captured in Table 5-1. Discussion of these costs, as broken down by work breakdown structure (WBS) elements, is provided in Section 4 and summarized in Appendix B of the preliminary project execution plan (DOE-ID 2011b). The expected accuracy range associated with the target values is defined by lower $(-15 \%)$ and upper $(+20 \%)$ bounds.

Table 5-1. Total project costs.

\begin{tabular}{lccc}
\hline Project Cost Element & $\begin{array}{c}\text { Lower Bound } \\
(\mathbf{S M}\end{array}$ & $\begin{array}{c}\text { Target } \\
(\mathbf{S M})\end{array}$ & $\begin{array}{c}\text { Upper Bound } \\
\text { (\$M) }\end{array}$ \\
\hline $\mathrm{TEC}^{\mathrm{a}}$ & 44.11 & 51.89 & 62.28 \\
\hline $\mathrm{OPC}^{\mathrm{a}}$ & 17.33 & 19.71 & 22.88 \\
\hline $\mathrm{DOE}^{-h e l d}$ contingency & 9.15 & 9.15 & 9.15 \\
\hline Total TPC & $\mathbf{7 0 . 5 9}$ & $\mathbf{8 0 . 7 5}$ & $\mathbf{9 4 . 3 1}$ \\
\hline a. Includes management reserve. & & & \\
\hline
\end{tabular}

TEC includes design and construction of the disposal facility using a design-build project delivery method. Included within TEC are all costs associated with disposal vaults, required facility infrastructure, procurement of a new onsite transport cask, and installation of monitoring wells. TEC also includes INL oversight and integration with the design-build subcontractors, development of final nuclear safety documentation, and project management and reporting during the construction phase, as appropriate. 
OPC includes costs associated with development of the following:

- $\quad$ Project concept

- $\quad$ Preparation of required NEPA (42 USC $\S 4321$ et seq.) documentation

- $\quad$ Preparation of safeguards and security documentation

- Development of the project performance baseline

- Development of performance specifications and requests for proposal for the design-build contracts for vaults, infrastructure, and transportation casks

- $\quad$ Development of the performance assessment and composite analysis (and supporting documentation) necessary to obtain a disposal authorization statement per DOE Order 435.1

- $\quad$ Relocation and refurbishment of equipment from RWMC to the new disposal facility to support operations

- Development of operations procedures

- $\quad$ Operations training.

Management reserve and DOE-held contingency are included in the TPC cost ranges, as reflected in Table 5-1 and Section 4.3 of the preliminary project execution plan (DOE-ID 2011b).

\subsection{Project Contingency}

In accordance with DOE Order 413.3B, contingency covers costs that may result from unforeseen and unpredictable conditions, or uncertainties that are external to the project, but that could affect its outcome. The amount of contingency held depends on the status of external uncertainties that could impact the project. Project contingency is developed for budget purposes only and is defined and managed by DOE.

Contingency will be held to address risk elements that are external to the scope of the project. Several risk elements that affect contingency have been identified. The analysis of these risks is included in the preliminary project execution plan (DOE-ID-2011b).

The cost profiles presented in this document and throughout the CD-1 documentation include a DOE-held contingency. All risk elements are captured in the risk management plan for the Remote-Handled LLW Disposal Project (PLN-2541).

The risk-based graded approach used to estimate contingency includes the following:

- Identifying all high or medium external risks (i.e., those risks that are dependent on government organizations to mitigate) as contributing to DOE-held contingency

- Identifying a reasonable assumed residual risk cost impact

- $\quad$ Summing the mitigation costs and the assumed residual risk cost impacts. 


\subsection{Funding Profile}

The funding profile for TPC, split into TEC and OPC, is shown in Figure 5-1. This funding is expressed using planned target point estimates, as contained in Table 5-1 and Section 4.3 of the preliminary project execution plan (DOE-ID 2011b) and reflects the receipt of capital funding from FY 2013 through 2016. A request for construction funds will be made in alignment with the federal budget cycle for FY 2013, approximately 15 months prior to submittal of the CD-2/3 approval request. The construction funds request can be made prior to CD-2/3 approval because the baseline will be established at the upper end of the cost range.

\subsection{Life-Cycle Costs}

Life-cycle costs for the proposed disposal facility are the sum of the direct, indirect, recurring, nonrecurring, and other related costs incurred or estimated to be incurred in the design, development, production, operation, maintenance, support, and final disposition of a system or facility over its anticipated useful life span. The life-cycle costs for the proposed INL remote-handled LLW disposal facility include TPC, operations costs during the operational life of the facility (FY 2018 to FY 2037), and costs associated with closure of the disposal facility. Figure 5-2 presents the life-cycle spending profile for the proposed disposal facility.

The total life-cycle cost for design, construction, operation, and closure of the proposed INL remote-handled LLW disposal facility is summarized in Table 5-2.

Table 5-2. Total life-cycle costs.

\begin{tabular}{lccc}
\hline Project Cost Element & $\begin{array}{c}\text { Lower Bound } \\
(\mathbf{S M})\end{array}$ & $\begin{array}{c}\text { Target } \\
(\mathbf{S M})\end{array}$ & $\begin{array}{c}\text { Upper Bound } \\
\text { (\$M) }\end{array}$ \\
\hline $\mathrm{TPC}^{\mathrm{a}}$ & 70.59 & 80.75 & 94.31 \\
\hline Operation costs & 82.12 & 102.66 & 133.47 \\
\hline Closure costs & 7.85 & 9.82 & 12.76 \\
\hline Total life-cycle costs & $\mathbf{1 6 0 . 5 6}$ & $\mathbf{1 9 3 . 2 3}$ & $\mathbf{2 4 0 . 5 4}$ \\
\hline a. Includes management reserve and DOE-held contingency. & & \\
\hline
\end{tabular}




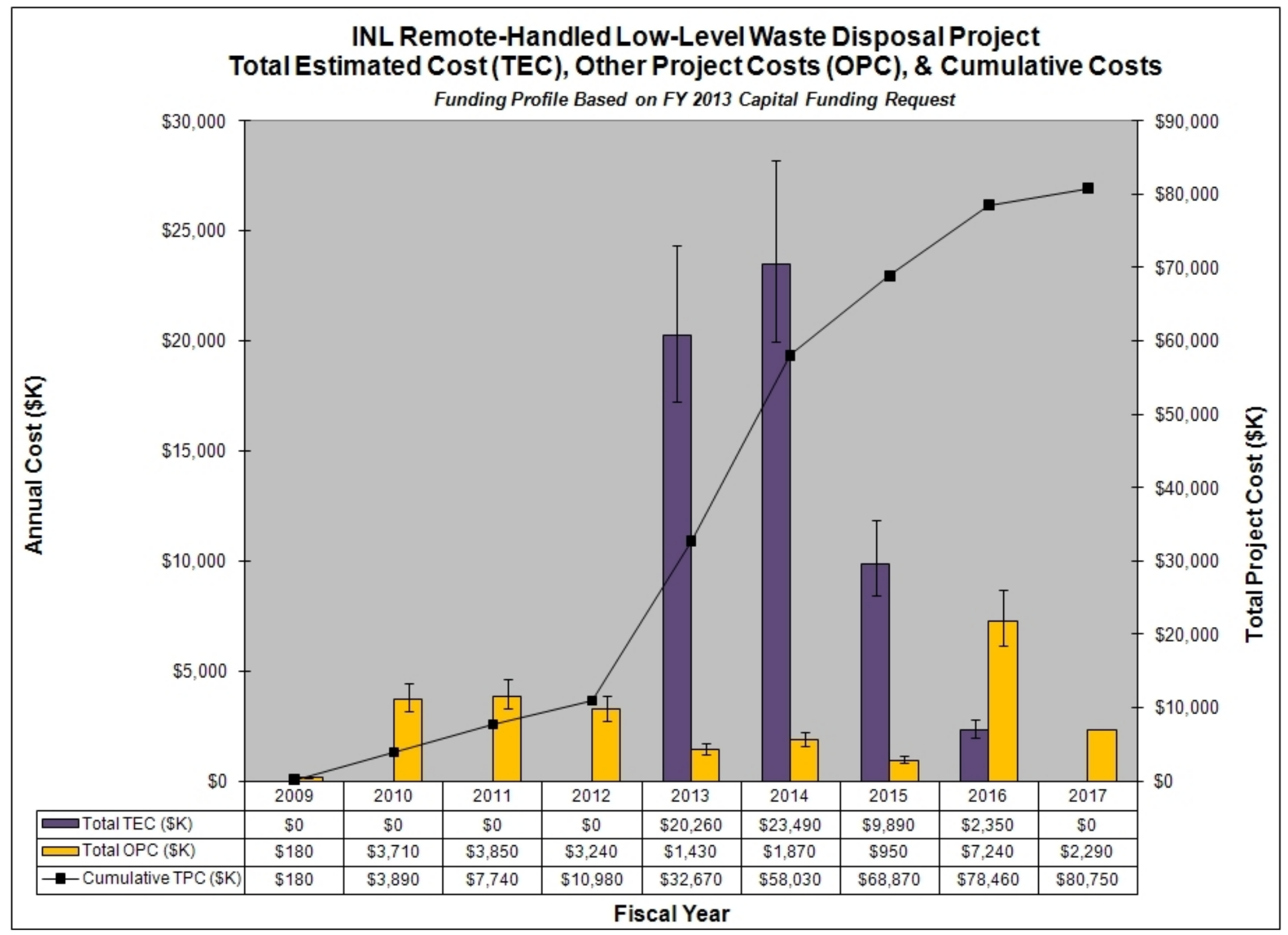

Figure 5-1. Target funding profile for the Remote-Handled Low-Level Waste Disposal Project. 


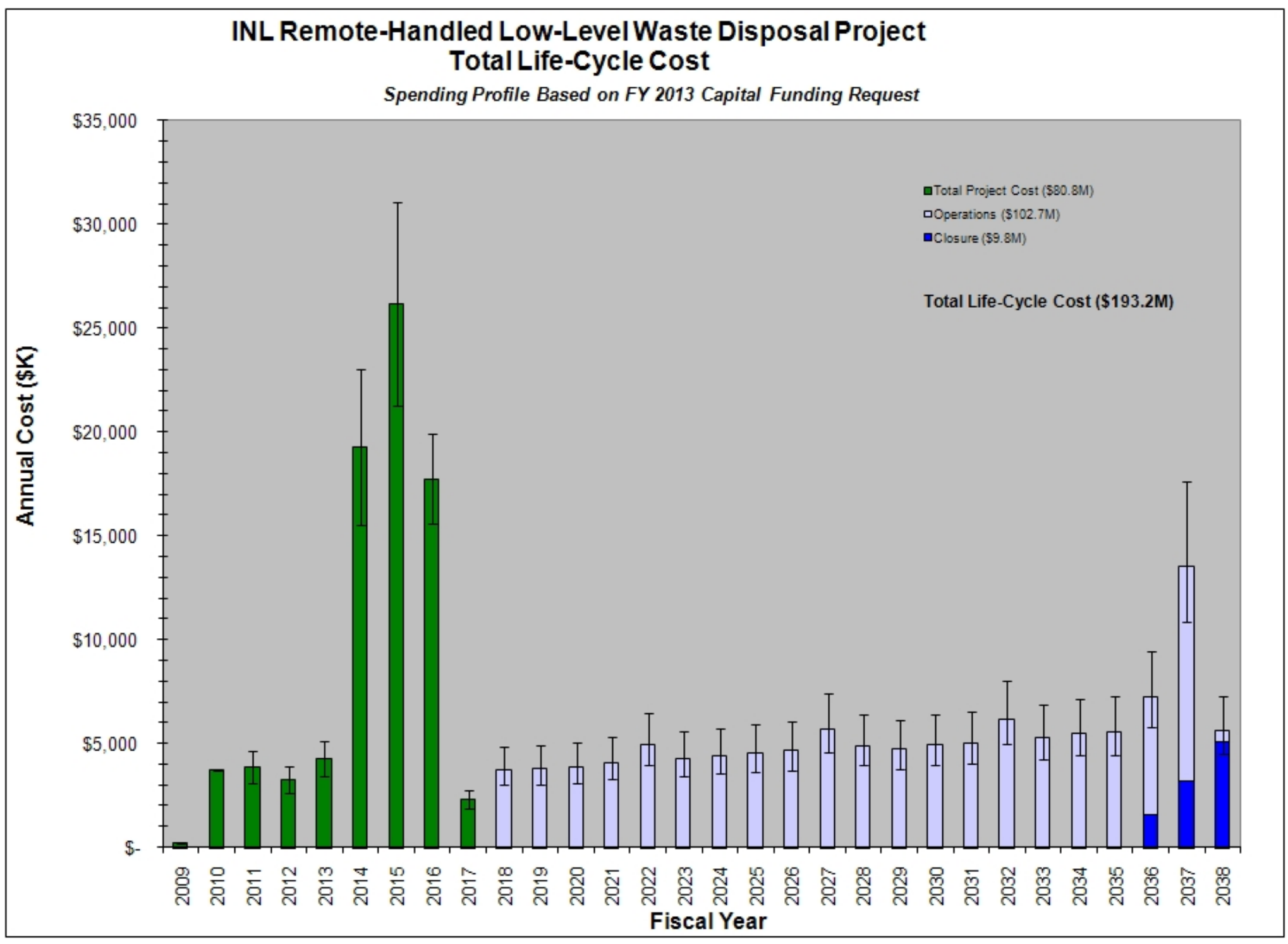

Figure 5-2. Idaho National Laboratory Remote-Handled Low-Level Waste Disposal Facility target life-cycle spending profile. 


\section{SCHEDULE}

\subsection{Summary Project Schedule}

The life-cycle schedule for the proposed remote-handled LLW disposal facility is comprised of three phases: (1) project planning and execution (FY 2009 through FY 2017), (2) operations (FY 2018 through FY 2037), and (3) closure (FY 2036 through FY 2038).

\subsubsection{Project Planning and Execution}

Project planning and execution will be conducted in accordance with the requirements of DOE Order 413.3B. The timeframe for meeting CD milestones is presented in Section 6.2. Project planning and execution began with development of remote-handled LLW disposal options and development of this conceptual design report and associated documentation and culminates with Acquisition Executive approval for start of operations. Disposal facility construction, involving construction of infrastructure and installation of disposal vaults, is assumed to take approximately 1.5 years, beginning in the second quarter of FY 2014.

Some of the potential critical path activities that would be conducted during project planning and execution include the following:

- Development and DOE Headquarters approval of the radiological performance assessment and composite analysis in accordance with DOE Order 435.1

- Concurrent with development of the environmental assessment, identification of a specific location for the proposed remote-handled LLW disposal facility

- $\quad$ Disposal facility waste acceptance criteria development

- $\quad$ Nuclear safety documentation (preliminary documented safety analysis and documented safety analysis) development and DOE approval

- $\quad$ Performance specifications and design-build requests for proposal development for the transport cask and infrastructure procurements

- $\quad$ Final design and request for proposal development for the vault disposal system construction.

\subsubsection{Disposal Facility Operations}

Disposal facility operations are proposed to commence no later than the first quarter of FY 2018 to support uninterrupted remote-handled LLW disposal capability. The facility would be constructed with sufficient capacity to support an initial 20-year operational period. Based on this capacity, the disposal facility would operate through the fourth quarter of FY 2037. The actual disposal facility operational life could be shorter or longer, dependent on the actual volume of waste disposed annually. Operations costs presented in Section 5 reflect costs for disposal campaigns at the facility, maintenance, monitoring, and maintaining the proposed facility's disposal authorization.

\subsubsection{Closure}

It is assumed that closure activities for the proposed disposal facility would commence in FY 2036, approximately 1 year before the last receipt of remote-handled LLW at the disposal facility with 
decontamination and demolition planning for the aboveground structures and supporting infrastructure and final cover/cap design. Final cover/cap installation would commence in FY 2037 to the extent that final waste placement activities would not be negatively impacted. Following placement of the final waste, the cover/cap would be completed and facility decontamination and decommissioning activities would be conducted with final closure of the disposal facility completed in FY 2038 (one year following last receipt of remote-handled LLW at the disposal facility). The specific dates for closure would depend on the actual disposal facility operational life, which could be shorter or longer, based on the actual volume of waste disposed of annually.

\subsection{Project Critical Decision Timeframe}

The CD timeframe for the INL Remote-Handled LLW Disposal Project is 2009 through 2017. The CD milestones support a FY 2017 project completion date (see Table 6-1). Additional details on key milestones and events are provided in Section 4.2 of the preliminary project execution plan (DOE-ID 2011b).

Table 6-1. Critical decision milestones for the Remote-Handled Low-Level Waste Disposal Project.

\begin{tabular}{lc}
\multicolumn{1}{c}{ Description } & $\begin{array}{c}\text { Planned Dates } \\
\text { (A=Actual) }\end{array}$ \\
\hline CD-0, Approve Mission Need & $07 / 2009 \mathrm{~A}$ \\
\hline CD-1, Approve Alternative Selection and Cost Range & $06 / 2011$ \\
\hline CD-2/3, Approve Performance Baseline and Start of Construction/Fabrication & $12 / 2012$ \\
\hline Final Design Complete & $08 / 2013$ \\
\hline Approve Start of Construction & $05 / 2014$ \\
\hline Construction/Fabrication Complete & $10 / 2016$ \\
\hline CD-4, Approve Start of Operations & $09 / 2017$ \\
\hline
\end{tabular}

Approval of CD-1, including the conceptual safety design report, is being sought and is planned for the third quarter of FY 2011.

The CD-2/3 request will include approval of the project baseline, updated project documents, the design-build procurement package, and authorization to initiate construction activities. In addition, the CD-2/3 request will have appropriate hold points (e.g., final design complete) prior to obtaining authorization to start construction and fabrication activities.

The CD-4 request supports approval for start of operations before the end of FY 2017, when the current remote-handled LLW disposal capability at RWMC is planned to cease. By adopting this approval sequence, the project is appropriately aligned with the DOE Order 413.3B.

\subsection{Work Breakdown Structure}

The WBS (to the work package level) can be found in the preliminary project execution plan (DOE-ID 2011b). The WBS will identify the proposed project through start of operations. The WBS is organized around the DOE Order 413.3B CD process, wherein a design-build project delivery method is used. 


\section{NUCLEAR SAFETY}

\subsection{Hazard Analysis and Classification}

With respect to nuclear safety, a hazard is defined as "a source of danger (i.e., material, energy source, or operation) with the potential to cause illness, injury, or death to personnel or damage to an operation or to the environment (without regard for the likelihood or credibility of accident scenarios or consequence mitigation)." To identify potential facility hazards, the following were examined:

- The quantity, form, and location of radioactive and hazardous materials that would be potentially releasable from the proposed remote-handled LLW disposal facility

- $\quad$ Potential energy sources and potential initiating events that could directly result in injury to workers or lead to release of radioactive or hazardous materials.

The strategy for integrating safety into the design process is described in the safety design strategy (INL 2010a). Based on the preliminary assessment of the anticipated remote-handled LLW waste stream, the evaluation of the design base accident scenarios, and a comparison with DOE-STD-1027-92, "Hazard Categorization and Accident Analysis Techniques for Compliance with DOE Order 5480.23, Nuclear Safety Analysis Reports," the Remote-Handled LLW Disposal Facility Project would have an initial hazard categorization as a Hazard Category 2 nuclear facility. The preliminary hazards evaluation is described in the conceptual safety design report (INL 2010b).

The primary driver for this determination is related to the total radionuclide inventory that would go to the facility in its entirety. However, DOE-STD-1027-92 supplemental guidance provides for facility categorization being modified in the final hazard categorization process considering (1) alternative release fractions or (2) change in material subject to an accident due to facility features that preclude bringing material together or causing harmful interaction from a common severe phenomenon (facility segmentation). These provisions will be further evaluated during development of the preliminary documented safety analysis and documented safety analysis per NS-18101, "INL Safety Analysis Process," to determine if modification to the facility hazard category is appropriate based on the facility segmentation consideration.

\subsection{Safety-Class System Classification}

Safety-class structures, systems, and components are hazard controls for which credit is taken, either preventive or mitigative, to meet the evaluation guidelines for offsite public. In accident cases evaluated for the remote-handled LLW disposal facility, evaluation guidelines are not challenged as unmitigated analyses. Therefore, no safety-class structures, systems, and components are identified or required for this facility.

Safety-significant structures, systems, and components are hazard controls for which credit is taken to prevent or mitigate postulated anticipated or unlikely accidents that could result in consequences to collocated or facility workers exceeding $25 \mathrm{rem}$. Radiation dose consequences from accidents evaluated in this document do not challenge $25 \mathrm{rem}$; therefore, they do not require safety-significant structures, systems, and components.

The vaults are located below ground surface, isolating contents from facility workers, and, upon failure, would not impose any risk of fatality or serious injury to workers. There are no failure scenarios for the vaults or shield plugs that result in a loss of function in an emergency that may be needed to preserve the health and safety of workers. Furthermore, in the improbable event of vault or shield plug failure, there would be no significant offsite consequences. 


\subsection{Seismic Design Category}

Based on an initial review of the applicable facility hazards and in accordance with Section 4 of ANSI/ANS-2.26-2004, the remote-handled LLW disposal facility seismic design category will be Seismic Design Category 1 . This determination is based on the assumption that failure of a vault will not cause radiological material to be brought to the surface and that it will remain in place without causing significant radiological exposure to workers, the public, or the environment. As stated in the standard, no Limit State identification is required for Seismic Design Category 1 systems, and the seismic evaluation on the facility will be performed in accordance with IBC (2009).

\subsection{Emergency Preparedness}

The INL Emergency Management Department plans and implements a compliant, proactive, risk-based program developed in accordance with DOE Order 151.1C, "Comprehensive Emergency Management System." The program will be used to respond to and mitigate consequences of emergencies that might arise at INL. Emergency Management's core planning and readiness assurance functions include the following:

- Determining hazards and credible events that could result in emergency situations

- $\quad$ Preparing for those situations through development of a trained Emergency Response Organization

- $\quad$ Procuring and maintaining emergency equipment and facilities

- $\quad$ Determining protective actions

- Developing standards and techniques for notifications, categorization/classification, consequence assessment, reentry, medical support, and program administration

- $\quad$ Providing timely and accurate public information

- Identifying the diverse elements involved in recovery and reentry.

Activities associated with the proposed remote-handled LLW disposal facility will be included within the framework of INL's existing Emergency Management System.

\subsection{Criticality}

In the conceptual design stage of the facility, preliminary evaluations indicate that the waste streams for the facility do not contain significant quantities of fissionable material to make nuclear criticality a credible accident. Further evaluation will be made on the need for criticality safety requirements (i.e., specific packaging configurations for high fissile materials) pertaining to the proposed remote-handled LLW disposal facility during development of the preliminary documented safety analysis. 


\section{SAFEGUARDS AND SECURITY}

\subsection{Safeguards}

The waste streams destined for the proposed remote-handled LLW disposal facility are classified as remote-handled LLW. The waste contains little fissile material and poses minimal risk of diversion because of the inherently self-protecting configuration and characteristics (i.e., high radiation) of the waste, as packaged. Based on these factors, the proposed facility (as designed and located) would require, at most, a property protection area as security controls. A Preliminary Security Vulnerability Assessment was completed to evaluate security requirements for the proposed facility. The following sections summarize the security measures needed to maintain the appropriate level of property protection.

\subsection{Property Protection Area}

A property protection area is a security area established for protection of DOE property and will protect against damage, destruction, or theft of government-owned property. A property protection area fence (or perimeter fence) would be provided for the proposed facility that is a minimum of $8 \mathrm{ft}(2.4 \mathrm{~m})$ high with a lockable gate. The facility also would be equipped with a security system that includes remote visual capabilities and wireless alarms that can be monitored at an offsite location. This system would be comprised of a camera network that would monitor the access gate to the facility and other locations as warranted. The network signals would provide remote video surveillance and indications of when the facility gate is open and closed. The monitoring location would be determined by the INL security organization. This system would be equipped with 8 hours of backup power.

Additional access controls that may be required, as determined by INL contractor security, include the following:

- $\quad$ Signs prohibiting trespassing posted around the perimeter and at each entrance to the property protection area in accordance with 10 CFR 860, "Trespassing on Administration Property," and 41 CFR 101-19.3, "Federal Property Management Regulation"

- Vehicles and personal property inspections to deter and detect unauthorized removal of government assets.

\subsection{Classified Waste Considerations}

Some waste component configurations received from NRF will be "classified shapes," qualifying them as National Security Information. However, the waste streams (as received) would be self-protecting (i.e., the radiation fields presented by the unshielded materials prevent examination without protective facilities). Additionally, all materials are sealed in a waste container (or cask liner) before leaving the protected areas and before shipment to the remote-handled LLW disposal facility. The DOE Naval Reactors Laboratory Field Office has approved disposal of classified NRF LLW by burial at the existing INL facility based on these considerations (DOE-NR 2008). Additional measures would be required for protection of the waste material at this facility.

\subsection{Additional Security Considerations}

Insider threats and sabotage risks are similar in nature to the current operational portfolio in place at RWMC. Therefore, the security impact of the proposed remote-handled LLW disposal facility should 
have minimal additional impact to the existing INL security program and should be consistent with current practices and operational risks at RWMC.

A formal review would be conducted, based on the final design and location of the facility, to determine if additional security concerns exist based on material types and quantities. This analysis would be conducted before the start of operations to ensure adequate security measures are in place and operational.

Consistent with DOE Order 420.1B, "Facility Safety," facility design would accommodate all requirements for safeguards and security, access control, and emergency egress. Where conflict occurs between such requirements, life safety requirements have precedence. As designed, this facility would comply with the letter and intent of the order and present no risk to employees with respect to NFPA 101. 


\section{ENVIRONMENTAL, SAFETY, AND HEALTH REQUIREMENTS}

Each of the following subsections provides a brief description of the statutes, regulations, orders, and agreements that have been identified as potentially applicable to the proposed remote-handled LLW disposal facility, as envisioned in the conceptual design. The construction and operation of the proposed remote-handled LLW disposal facility will be in compliance with the applicable environmental, safety, and health compliance requirements identified in this section.

All work at INL will be conducted in accordance with INL's DOE-approved Integrated Safety Management System and DOE Manual 450.4-1, "Integrated Safety Management System Manual." The objective of the Integrated Safety Management System is to provide a safe workplace to perform work while protecting the worker, the public, and the environment by incorporating safety into management and work practices at all levels and by addressing all types of work and all types of hazards. "Safety" encompasses safety and health, quality assurance, and the environment, including pollution prevention and waste minimization.

\subsection{Department of Energy Orders}

DOE facilities are regulated by DOE for LLW management, radiation protection, and safety. This section describes the key requirements that apply to the proposed remote-handled LLW disposal facility.

\subsubsection{DOE Order 435.1, Radioactive Waste Management}

DOE Order 435.1 establishes requirements to ensure that all DOE radioactive waste is managed in a manner that is protective of workers, public health and safety, and the environment. The requirements contained within DOE Order 435.1 directly pertain to the design of the proposed remote-handled LLW disposal facility.

The DOE Manual 435.1-1 identifies the specific requirements for the management of all radioactive waste. The specific requirements associated with management of low-level radioactive waste include the following:

1. Radioactive waste management basis-Facilities, operations, and activities will have a radioactive waste management basis consisting of the following physical and administrative controls to ensure protection of workers, public, and the environment: the performance assessment, composite analysis, disposal authorization statement, closure plan, waste acceptance requirements, and monitoring plan.

2. Waste acceptance-Waste acceptance requirements for waste storage, treatment, and disposal of LLW must include the following, at a minimum:

- $\quad$ Allowable activities or concentrations of specific radionuclides

- Acceptable waste form or container requirements that ensure the chemical and physical stability of waste under conditions that might be encountered during transportation, storage, treatment, or disposal

- $\quad$ Restrictions or prohibitions on waste, materials, or containers that may adversely affect waste handlers or compromise facility or waste container performance 
- LLW must contribute to and not detract from achieving long-term stability of the facility, minimizing the need for long-term active maintenance, minimizing subsidence, and minimizing contact or water with waste (void spaces within the waste and, if containers are used, between the waste and its container must be reduced to the extent possible).

- $\quad$ LLW must not be readily capable of detonation, explosive decomposition, or reaction at anticipated pressures and temperatures or of explosive reaction with water; pyrophoric materials contained in waste must be treated, prepared, and packaged to be nonflammable

- $\quad$ LLW must not contain or be capable of generating by radiolysis or biodegradation quantities of toxic gases, vapors, or fumes harmful to the public, workers, or disposal facility personnel, or harmful to the long-term structural stability of the disposal site.

3. Waste exceptions - The basis, procedure, and levels of authority required for granting exceptions to the waste acceptance requirements must be contained in each facility's waste acceptance documentation. Each exception request must be documented, including its disposition, as approved or not approved.

4. Waste generation plan-Includes life-cycle planning and conditions for generation of waste with no identified path to disposal.

5. Waste characterization - Characterization requirements for waste to ensure safe management and compliance with waste acceptance requirements of the facility receiving the waste.

6. Waste certification-A program to ensure that waste acceptance requirements of facilities receiving waste for storage, treatment, and disposal are met.

7. Waste transfer-A documented process transferring responsibility for management of the waste and ensuring availability of relevant data.

8. Packaging and transportation-Packaging and transportation requirements.

9. Site evaluation and facility design-Requirements to ensure environmental characteristics, geotechnical characteristics, and human activities are evaluated.

10. Storage and staging requirements - Includes storage prohibitions, integrity requirements, and inspection requirements.

11. Treatment-Waste will be treated, as necessary, to meet the waste acceptance requirements of the facility receiving the waste for storage or disposal.

12. Disposal—Disposal requirements for the waste.

13. Monitoring-Monitoring requirements for waste, including stored waste.

\subsubsection{DOE Order 450.1, Environmental Protection Program}

DOE Order 450.1, "Environmental Protection Program," ensures implementation of sound stewardship practices that are protective of the air, water, land, and other natural and cultural resources impacted by DOE operations and by which DOE cost effectively meets or exceeds compliance with applicable environmental, public health, and resource protection laws, regulations, and DOE 
requirements. As required by the order, all DOE elements must ensure that the Integrated Safety Management System includes an environmental management system component that provides for public health and environmental protection, pollution prevention, and compliance with applicable environmental protection requirements.

While requirements of DOE Order 450.1 help ensure that INL meets all applicable environmental requirements, there are no specific additional environmental compliance requirements contained within DOE Order 450.1 that are not contained elsewhere in referenced regulations that directly pertain to the design, construction, and operation of the proposed remote-handled LLW disposal facility.

\subsubsection{DOE Order 420.1B, Facility Safety}

DOE Order 420.1B, "Facility Safety," establishes facility safety requirements for nuclear safety design, criticality safety, fire protection, natural phenomena hazards mitigation, and a system engineer program. These requirements are addressed in the preliminary hazard assessment.

\subsubsection{DOE Order 5400.5, Radiation Protection of the Public and the Environment}

DOE Order 5400.5, "Radiation Protection of the Public and the Environment," establishes standards and requirements for operation of DOE and DOE contractors with respect to protection of members of the public and the environment against undue risk from radiation. The objectives of the order include the following:

1. Operate facilities and conduct activities so that radiation exposures to members of the public are maintained within limits established in the order and to control radioactive contamination through management of real and personal property

2. Maintain potential exposures to members of the public as far below the limits as reasonably achievable and to have the capabilities, consistent with the types of operations conducted, to monitor routine and non-routine releases and to assess doses to members of the public

3. Protect the environment from radioactive contamination to the extent practical.

The order sets a primary standard of 100 mrem effective dose equivalent to members of the public in a year. To the extent required by the Clean Air Act (see Section 9.3), the exposure of members of the public to radioactive materials released to the atmosphere as a consequence of routine DOE activities will not cause members of the public to receive in a year, an effective dose equivalent greater than $10 \mathrm{mrem}$.

DOE Order 5400.5 establishes radiation limits. Necessary engineering controls must be incorporated into the design to ensure that the dose limits specified in the order are met.

\subsection{Spent Fuel Settlement Agreement}

The Spent Fuel Settlement Agreement between DOE and the State of Idaho (DOE-ID 1995), and an associated Addendum (DOE-ID 2008), addresses receipt and storage of spent nuclear fuel at INL. INL may receive and store spent fuel for which DOE is responsible on the condition that all DOE spent fuel be removed from Idaho by January 1, 2035. Specific quantities of Naval spent nuclear fuel at INL may be received and stored for a timeframe reasonably necessary for examination, processing, and queuing for shipment to a repository or storage facility outside of Idaho. There are no compliance requirements contained within the agreement that pertain to conceptual design of a remote-handled LLW disposal facility. The Naval Nuclear Propulsion Program requires that disposal capability be available for 
the process of readying spent nuclear fuel for final disposition. Continued access to remote-handled LLW disposal capacity is critical to the Navy's mission and ensures provisions in the Idaho Settlement Agreement are met.

\subsection{Clean Air Act}

The primary objective of the Clean Air Act (42 USC 7401 et seq.) is for EPA to establish federal limits for certain air pollutants, including radionuclides, in the atmosphere to ensure basic and environmental health protection. A state develops a state implementation plan, which is a collection of regulations that the state uses to prevent air pollution. The State of Idaho has an approved state implementation plan and the regulations are found in IDAPA.

IDAPA 58.01.01.201 requires that a "permit to construct" be issued for new sources: "No owner or operator may commence construction or modification of any stationary source, facility, major facility, or major modification without first obtaining a permit to construct from DOE, which satisfies the requirements of Section 200 through 228 unless the source is exempted." Application procedures to obtain a permit to construct are identified in IDAPA 58.01.01.202.

In addition to the State of Idaho "permit to construct," the requirements of the National Emissions Standards for Hazardous Air Pollutants must be considered as potentially applicable to the project. INL is subject to 40 CFR 61.90 through 61.97 as stated, "The provisions of this subpart apply to operation of any facility owned or operated by the Department of Energy that emits any radionuclide other than radon-222 and radon-220 into the air." Section 40 CFR 61.96 states that such a facility that has the potential for an unmitigated effective dose equivalent to a member of the public greater than or equal to $0.1 \mathrm{mrem} / \mathrm{year}$, as calculated using the method in 40 CFR Part 61 Appendix D, must submit an application to construct to EPA Region 10 and receive approval before construction begins. Potential radioactive emissions associated with the operation of the proposed remote-handled LLW disposal facility will be calculated and discussed in the NEPA documentation being prepared for this project and as described in Section 9.6. This information will be used to determine the Clean Air Act compliance requirements that must be addressed.

These requirements are based upon release of radionuclides from the operation of the facility and require submittal and approval before construction. The requirements are not directly related to the design phase of the proposed remote-handled LLW disposal facility. However, DOE Order 435.1 (Section 9.1.1) does establish requirements to ensure that all DOE radioactive waste is managed in a manner that is protective of workers, public health and safety, and the environment. The requirements contained within DOE Order 435.1 directly pertain to the design of the proposed remote-handled LLW disposal facility.

\subsection{Comprehensive Environmental Response, Compensation, and Liability Act}

CERCLA, commonly known as Superfund, created a tax on the chemical and petroleum industries and provided broad federal authority to respond directly to releases or threatened releases of hazardous substances that may endanger public health or the environment. CERCLA established prohibitions and requirements concerning closed and abandoned hazardous waste sites.

The CERCLA program was extended through the Superfund Amendments and Reauthorization Act of 1986 (PL 99-499). Title III of Superfund Amendments and Reauthorization Act, known as the Emergency Planning and Community Right-to-Know Act, established requirements for federal, state, and 
local governments; Indian Tribes; and industry regarding emergency planning and "Community Right-toKnow" reporting on hazardous and toxic chemicals.

The NEPA process and documentation will discuss the actual location of the proposed remote-handled LLW disposal facility. Location of a remote-handled LLW disposal facility within a CERCLA site could involve concerns about worker exposure during construction and increased environmental monitoring responsibilities. Therefore, avoiding any existing CERCLA sites is a criterion in the siting selection to establish a location for the remote-handled LLW disposal facility. CERCLA waste would not be disposed of at the proposed remote-handled disposal facility. Therefore, there are no CERCLA environmental-compliance requirements that pertain to the conceptual design of the proposed remote-handled LLW disposal facility.

\subsection{Federal Facilities Agreement and Consent Order}

The Federal Facilities Agreement/Consent Order (DOE-ID 1991) establishes a process under both the RCRA and CERCLA for evaluating past potential releases to the environment at INL, determining the risk any releases may pose to human health and the environment, and evaluating potential remedies. There are no environmental compliance requirements contained in the Federal Facilities Agreement/Consent Order that directly pertain to the design, construction, and operation of the proposed remote-handled LLW disposal facility.

\subsection{National Environmental Policy Act}

NEPA is the national charter for environmental planning. NEPA requires that the effects of federal actions on the environment be considered equally with economic, technical, and other factors associated with the proposed action. NEPA establishes an analytical process for federal agency decision-making. This process requires that for federal actions having the potential to significantly impact the environment, agencies must do the following:

1. Identify and analyze environmental consequences of proposed federal actions in comparable detail to economic and operational analyses

2. Assess reasonable alternatives to agency proposed actions

3. Document the environmental analysis and findings

4. Make environmental information available to public officials and citizens before agency decisions are made.

A NEPA evaluation, in the form of an environmental assessment, will be performed for the activities associated with the proposed remote-handled LLW disposal facility. The environmental assessment will evaluate the alternatives of locating a disposal facility on INL, using an offsite facility, and taking no action. The final decision will be based on the overall impacts to the environment along with other factors, such as cost and long-term performance. If the proposed activities do not significantly impact the environment, then a finding of no significant impact will be issued. The finding of no significant impact may address measures that an agency will take to reduce (mitigate) potentially significant impacts. If the environmental assessment identifies significant impacts, then an environmental impact statement will be prepared. 


\subsection{Department of Energy/Tribal Agreement in Principle}

The DOE/Tribal Agreement (DOE 2002) defines interfaces between DOE and the Shoshone-Bannock tribes. The agreement also describes the technical and financial assistance DOE will provide the tribes. As part of the NEPA process (see Section 9.6), the Shoshone-Bannock tribes will have the opportunity to provide comments pertaining to the operation of the proposed remote-handled LLW disposal facility.

\subsection{Environmental Oversight and Monitoring Agreement}

The goals of this agreement are to maintain an independent, impartial, and qualified State of Idaho INL Oversight Program to assess the potential impacts of present and future DOE activities in Idaho; to assure the citizens of Idaho that all present and future DOE activities in Idaho are protective of the health and safety of Idahoans and the environment; and to communicate the findings to the Idaho citizens in a manner that provides them the opportunity to evaluate potential impacts of present and future DOE activities in Idaho.

\subsection{Idaho National Laboratory Labor Terms and Conditions}

The INL Site Stabilization Agreement (DOE 1991) is a collective bargaining agreement between INL employers (contractors and subcontractors) performing construction work (determined by the Owner to be covered by the Davis Bacon Act) and the Building and Construction Trades Department of the AFL-CIO, the Idaho Building and Construction Trades Council, the International Unions affiliated therewith, the International Brotherhood of Teamsters, Chauffeurs, Warehousemen and Helpers of America, and the signatory local unions.

The Site Jurisdictional Agreement, also known as the INL Site Construction Jurisdictional Procedure Agreement, coupled with the Site Stabilization Agreement establish the labor terms and conditions including wages, hiring procedures, and other employment practices associated with the INL construction projects. There are no compliance requirements contained within the agreements that directly pertain to the proposed remote-handled LLW disposal facility, as envisioned in the conceptual design.

\subsection{Safe Drinking Water Act/ldaho Regulations for Public Drinking Water Systems}

The Safe Drinking Water Act (42 USC 300(f) et seq.) was established to protect the quality of drinking water in the United States. The law focuses on all the waters actually or potentially designated for drinking use, whether from aboveground or underground sources. The act provides for establishment of primary regulations for the protection of the public health and secondary regulations relating to taste, odor, and appearance of drinking water.

In accordance with IDAPA 58.01.08.550, public drinking water systems must conform to the rules in IDAPA 58.01.08 and "Recommendation Standards for Water Works, A Report of the Water Quality Supply Committee of the Great Lakes-Upper Mississippi River Board of State and Provincial Public Health and Environmental Managers," except Parts 1 and 8. A public water system is defined as a system that serves 25 people for at least 60 days per year. 
The proposed remote-handled LLW disposal facility may require establishment of a public drinking water system, depending on availability of drinking water at the location that is selected. If a drinking water system is required, facility and design standards for the following elements and activities would be incorporated in compliance with IDAPA 58.01.08.550:

- $\quad$ Siting and construction of wells

- Disinfection

- Contaminant control and treatment

- $\quad$ Pumping facility

- Distribution systems

- Cross-connection control

- $\quad$ Operating criteria.

\subsection{Water Regulations}

The Clean Water Act (33 USC 1251 et seq.) establishes the basic structure for regulating discharges of pollutants into the waters of the United States. The act provides EPA the authority to implement pollution control programs (i.e., setting wastewater standards for industry). The Clean Water Act also sets water quality standards for all contaminants in surface waters. The State of Idaho has jurisdiction over the land application of wastewaters (IDAPA 58.01.17). Anyone wishing to land-apply wastewater must obtain a wastewater land application permit before constructing, modifying, or operating a wastewater land application facility in the State of Idaho.

According to TFR-483, no wastewaters from operation of the remote-handled LLW disposal facility are anticipated to be generated. However, depending on the specific location of the facility and the availability of existing sanitary facilities, a new individual subsurface disposal system or portable non-discharging wastewater system may be required. The State of Idaho has regulations and a technical guidance manual governing individual/subsurface sewage disposal (IDAPA 58.01.03). Under the Idaho program, the following applies:

- If a permanent facility is not available and installation is impractical, under IDAPA 58.01.03.005, a portable non-discharging system may be installed if it is properly maintained and of a design approved by the Director of the Idaho Department of Environmental Quality.

- If a permanent facility is determined to be required, a permit from the State of Idaho would be obtained as required under IDAPA 58.01.03.005. The permit application would address design and operating parameters for the wastewater disposal system, including the following:

- $\quad$ Maximum number of persons served

- $\quad$ Type of system

- $\quad$ Soil description and profile, groundwater data, percolation or permeability test results, and a site evaluation report 
- Nature and quantity of wastewater that the system is to receive

- $\quad$ Proposed operation, maintenance, and monitoring procedures to ensure the system's performance and failure detection.

\subsection{Hazardous Waste Management Act/Resource Conservation and Recovery Act and Related Requirements}

The Resource Conservation and Recovery Act of 1976 (42 USC $\S 6901$ et seq.) amended the Solid Waste Act of 1965. In 1984, Congress passed the Hazardous and Solid Waste Amendments, which expanded the scope of the RCRA Program. Provisions of Subtitle C of RCRA, "Hazardous Waste Management," provide EPA and the State of Idaho authority to establish regulations for the identification and listing of hazardous waste and management standards applicable to the generation, transport, and disposal of hazardous waste. RCRA regulations are enforced by the State of Idaho through the Hazardous Waste Management Act.

Waste subject to regulation under Subtitle C of RCRA is materials that meet the definition of a hazardous waste. The waste to be disposed of in the remote-handled LLW disposal facility is remote-handled LLW only. Therefore, there are no RCRA Subtitle C hazardous waste compliance requirements that pertain to conceptual design of the proposed remote-handled LLW disposal facility.

Subtitle D of the Hazardous Waste Management Act/RCRA addresses non-hazardous solid waste. Pursuant to Subtitle D, EPA has set criteria for disposal of non-hazardous solid waste at municipal and non-municipal waste facilities. The remote-handled LLW would not be considered household or municipal waste. It could be considered non-municipal. However, under the Idaho rules that implement the federal criteria, radioactive wastes regulated under the Atomic Energy Act are excluded from regulation. Therefore, RCRA Subtitle D does not apply to this project (IDAPA 58.01.06.001.a.viii).

\subsection{Pollution Prevention and Waste Minimization}

Waste minimization activities should be incorporated and designed into all activities associated with the proposed remote-handled LLW disposal facility. Proper design criteria and optimization can greatly affect waste generation and are critical in pollution prevention. A strategy for the management and minimization of waste is determined by the waste management policy of DOE Order 435.1. The environmental management system component of the Integrated Safety Management System provides for the systematic planning, execution, and evaluation of the pollution prevention program. During the design of the facility, consideration should be given to construction processes and materials that will generate the least amount of waste and impacts on the environment. 


\section{RISK MANAGEMENT}

The project risk management plan (PLN-2541) defines the scope, responsibilities, and methodology for identifying, evaluating, quantifying, and managing risks that could affect successful completion of the project. The objective of the risk management plan is to enable project success by identifying project risks and appropriate response actions to effectively manage them through project completion. The risk management plan has been prepared in accordance with Laboratory-wide Procedure (LWP)-7350, "Project Risk Management," DOE Order 413.3B, and DOE Guide 413.3-7, "Risk Management Guide." The risk management plan was prepared to support the CD process and will be modified, as required, for subsequent project phases to meet project requirements. 
10-2 


\section{READINESS REVIEW}

This section addresses operational readiness before startup of the proposed remote-handled LLW disposal facility.

\subsection{Introduction}

The DOE requirements for startup and restart of nuclear facilities are contained in DOE Order 425.1C, "Startup and Restart of Nuclear Facilities." For initial startup of a new hazard category nuclear facility (i.e., the proposed remote-handled LLW disposal facility), DOE Order 425.1C specifies that DOE and the contractor must conduct an operational readiness review (ORR). An ORR is an activity that confirms that management has brought the facility to a state of readiness to commence or resume program work. The management effort for the readiness will include management self-assessment activities in preparation for the ORR. The INL process for management self-assessments is described in LWP-9903, "Performing Management Self-Assessments for Readiness," and the INL start and restart process is described in LWP-9902, "Startup and Restart of Nuclear Facilities." Once management concludes that readiness has been achieved, the state of readiness in independently verified by the DOE ORR.

The ORR is intended to confirm that the facility is in a state of readiness to safely conduct operations in accordance with the safety basis and that management control programs are in place to ensure safe operations can be sustained. A foundation for readiness of the nuclear facility is an approved safety basis as defined in approved facility safety documentation, approved environmental documentation, a satisfactory safe working environment, and compliance with DOE orders and requirements. The ORR team must verify that the necessary approved requirements documentation is in place and that procedures, personnel, equipment, and systems support the approved requirements.

\subsection{Plan-of-Action}

Before the projected date for the ORR, the INL contractor will prepare and submit for approval an ORR plan-of-action. The plan-of-action will provide the proposed breadth of the ORR, as specified by the core requirements in DOE Order 425.1C, the prerequisites for starting the ORR, the ORR schedule, the proposed ORR Team Leader, and other information required by DOE Order 425.1C. The ORR plan-of-action will be reviewed by the Operations Office Manager, or designee, and approved or forwarded to the designated approval authorities.

\subsection{Implementation Plan}

The approved plan-of-action is provided to the designated ORR Team Leader. The ORR Team Leader identifies the necessary team members who will conduct the ORR. The ORR Team Leader, with the assistance of the team, develops the ORR Implementation Plan. This plan describes how the ORR will be conducted. It will include checklists, evaluation criteria, review methodology, qualification requirements for the members, reporting expectations, and other information necessary to efficiently execute and report the results of the ORR. The INL contractor's line management will take action to bring the facility into a condition of readiness to start operations. As part of achieving readiness, management self-assessment activities are appropriate and will be included. 


\subsection{Contractor Operational Readiness Review}

The INL contractor's line management will determine that readiness has been achieved by meeting all prerequisites specified in the ORR plan-of-action. The INL contractor ORR will be conducted and reported in accordance with the ORR Implementation Plan. When prestart findings from the contractor ORR have been resolved, the INL contractor will prepare and forward a Readiness to Proceed Memorandum to DOE-ID.

\subsection{Department of Energy Operational Readiness Review}

Following receipt of the Readiness to Proceed Memorandum, the DOE-ID Manager, or designee, will concur with the contractor's readiness; verify DOE-ID management readiness, including meeting DOE prerequisites in the DOE plan-of-action; and recommend to DOE Headquarters that the DOE ORR be conducted. At the direction of DOE Headquarters, the DOE ORR will be conducted. Following completion of the DOE ORR and resolution of prestart findings, DOE management recommends to the authorization authority that startup approval be granted. Following this approval for startup, CD-4 approval will be issued. 


\section{QUALITY ASSURANCE}

The Quality Assurance Program (QAP) for the proposed remote-handled LLW disposal facility conceptual design must meet the minimum requirements of 10 CFR 830, "Nuclear Safety Management," DOE Order 413.3B, DOE Order 414.1C, "Quality Assurance," and the American Society of Mechanical Engineers NQA-1-2000, "Quality Assurance Requirements for Nuclear Facility Applications," as implemented using a graded approach through the applicable program areas of the DOE-ID approved INL QAP.

The INL Director of Quality Assurance is responsible for establishing, maintaining, and monitoring implementation of the overall INL QAP and for assisting the Idaho Facilities Management Program throughout the project life cycle. The INL QAP is a management system established to help the INL organization perform work correctly. The Remote-Handled LLW Disposal Project addresses each quality program area through PLN-3359, "Quality Assurance Program Plan for the Remote-Handled Low Level Waste Disposal Project."

The INL quality assurance organization is represented on the remote-handled LLW disposal facility integrated project team and has continued participation throughout all project phases. The methodology and approach used to meet various requirements are tailored appropriately (graded approach) in consideration of the complexity, cost, and risks associated with the project. The risk management plan for the Remote-Handled LLW Disposal Project (PLN-2541) defines the scope, responsibilities, and methodology for identifying, assessing impacts, and managing risks that could affect successful completion of the project.

The graded approach is an essential element used in establishing quality assurance requirements and is applied through the assignment of quality levels to items and activities at the earliest time consistent with application of the appropriate controls. Using LWP-13014, "Determining Quality Levels," Quality level evaluations for both design and construction activities were completed. The Quality Level-2 activities covered under Quality Level Determination MSA-000136 include preparation of the preliminary documented safety analysis, development of the performance specification, and development of the requisite DOE Order 435.1. The Quality Level-3 conceptual design activities and construction activities for the concrete waste disposal vaults are being completed under Quality Level Determination ALL-000191.

New facilities to support the Remote-Handled LLW Disposal Project are constructed in accordance with LWP-7201, "INL Construction," the approved engineering drawings and specifications (design criteria), and national codes and standards. Before the facility startup and operational turnover phase (CD-4) of the project, the QAP plan will be revised to address specific requirements for the various facilities and operating organizations based on the criteria of American Society of Mechanical Engineers NQA-1-2000 and the INL QAP. These criteria and the phases to which they apply are listed in Table 12-1. 
Table 12-1. American Society of Mechanical Engineers NQA-1-2000 criteria applicable to the proposed Remote-Handled Low-Level Waste Disposal Facility.

\begin{tabular}{|c|c|c|c|c|}
\hline & Criterion & Design Phase & Construction & $\begin{array}{c}\text { Facility Startup/ } \\
\text { Operation }\end{array}$ \\
\hline 1. & Organization & • & • & • \\
\hline 2. & QAP & • & • & $\bullet$ \\
\hline 3. & Design control & - & & - \\
\hline 4. & Procurement document control & $\bullet$ & • & $\bullet$ \\
\hline 5. & $\begin{array}{l}\text { Instructions, procedures, and } \\
\text { drawings }\end{array}$ & $\bullet$ & $\bullet$ & $\bullet$ \\
\hline 6. & Document control & - & • & $\bullet$ \\
\hline 7. & $\begin{array}{l}\text { Control of purchased items and } \\
\text { services }\end{array}$ & $\bullet$ & $\bullet$ & $\bullet$ \\
\hline 8. & Identification and control of items & & $\bullet$ & $\bullet$ \\
\hline 9. & Control of special processes & & & $\bullet$ \\
\hline 10. & Inspection & & • & $\bullet$ \\
\hline 11. & Test control & $\bullet$ & $\bullet$ & $\bullet$ \\
\hline 12. & $\begin{array}{l}\text { Control of measuring and test } \\
\text { equipment }\end{array}$ & & & $\bullet$ \\
\hline 13. & Handling, storage, and shipping & & & $\bullet$ \\
\hline 14. & Inspection, test, and operating status & & & $\bullet$ \\
\hline 15. & Control of nonconforming items & & $\bullet$ & $\bullet$ \\
\hline 16. & Corrective action & • & $\bullet$ & $\bullet$ \\
\hline 17. & Quality assurance records & $\bullet$ & $\bullet$ & $\bullet$ \\
\hline 18. & Audits & $\bullet$ & $\bullet$ & $\bullet$ \\
\hline
\end{tabular}




\section{REFERENCES}

10 CFR 61, "Licensing Requirements for Land Disposal of Radioactive Waste," Code of Federal Regulations, Office of Federal Register, April 4, 2007.

10 CFR 830, Subpart A, "Quality Assurance Requirements," Code of Federal Regulations, Office of the Federal Register, February 4, 2002.

10 CFR 835, "Occupational Radiation Protection," Code of Federal Regulations, Office of the Federal Register, July 11, 2007.

10 CFR 860, "Trespassing on Department of Energy Property," Code of Federal Regulations, Office of the Federal Register, March 4, 2004.

29 CFR 1926, "Safety and Health Regulations for Construction," Code of Federal Regulations, Office of the Federal Register, February 15, 2008.

41 CFR 101, "Federal Property Management Regulations," Code of Federal Regulations, Office of the Federal Register, May 1, 2008.

47 FR 57450, Federal Register Notification for 10 CFR 61.

33 USC 1251 et seq., "Clean Water Act,” United States Code, 2000.

42 USC § 300(f) et seq., "Safe Drinking Water Act," as amended, United States Code, 2000.

42 USC § 2011 et seq., “Atomic Energy Act of 1954,” as amended, 1954, United States Code, 2000.

42 USC § 4321 et seq., "National Environmental Policy Act of 1969 (NEPA)," United States Code, January 1970.

42 USC § 6901 et seq., 1976, "Resource Conservation and Recovery Act (Solid Waste Disposal Act)," United States Code, 2000.

42 USC § 7401, et seq., 1990, “Clean Air Act,” as amended, United States Code, 2000.

42 USC § 9601 et seq., "Comprehensive Environmental Response, Compensation, and Liability Act (CERCLA)," United States Code, January 2006.

ANSI/ANS 2.26-2004, "Categorization of Nuclear Facility Structures, Systems, and Components for Seismic Design," American National Standards Institute/American Nuclear Society.

ASME NQA-1-2000, "Quality Assurance Requirements for Nuclear Facility Applications," American Society of Mechanical Engineers, January 2000.

DOE, 1991, "INEEL Site Stabilization Agreement," U.S. Department of Energy (INEEL), Second Edition, October 1991.

DOE, 2002, "Agreement in Principle between the Shoshone-Bannock Tribes and the United States Department of Energy," U.S. Department of Energy, December 10, 2002. 
DOE Guide 413.3-7, "Risk Management Guide, U.S. Department of Energy, September 16, 2008.

DOE Manual 435.1-1, "Radioactive Waste Management Manual," Change 1, U.S. Department of Energy, July 9, 1999.

DOE Manual 450.4-1, “Integrated Safety Management System Manual,” U.S. Department of Energy, November 1, 2006.

DOE Order 151.1C, “Comprehensive Emergency Management System,” U.S. Department of Energy, November 2, 2005.

DOE Order 413.3B, "Program and Project Management for Acquisition of Capital Assets,"

U.S. Department of Energy, October 2010.

DOE Order 414.1C, “Quality Assurance,” U.S. Department of Energy, June 17, 2005.

DOE Order 420.1B, “Facility Safety,” U.S. Department of Energy, December 22, 2005.

DOE Order 425.1C, "Startup and Restart of Nuclear Facilities," U.S. Department of Energy, March 13, 2003.

DOE Order 430.1B, “Real Property Asset Management,” U.S. Department of Energy, February 8, 2008.

DOE Order 430.2B, "Renewable Energy and Transportation Management," U. S. Department of Energy, February 27, 2008.

DOE Order 435.1, "Radioactive Waste Management," Change 1, U.S. Department of Energy, July 9, 1999.

DOE Order 450.1, “Environmental Protection Program,” U.S. Department of Energy, January 15, 2003.

DOE Order 5400.5, "Radiation Protection of the Public and the Environment," Change 2,

U.S. Department of Energy, January 7, 1993.

DOE Guide 413.3-13, “Acquisition Strategy Guide for Capital Asset Projects," U.S. Department of Energy, July 22, 2008.

DOE-HDBK-1092, "DOE Handbook: Electrical Safety."

DOE-ID, 1991, "Federal Facility Agreement and Consent Order for the Idaho National Engineering Laboratory," Administrative Record No. 1088-06-29-120, U.S. Department of Energy Operations Office; U.S. Environmental Protection Agency, Region 10; Idaho Department of Health and Welfare, December 4, 1991.

DOE-ID, 1995, "Settlement Agreement," Settlement between the State of Idaho, Department of Energy, and Department of Navy. Document available at http://idahocleanupproject.inel.gov/Portals/0/documents/1995SettlementAgreement.pdf.

DOE-ID, 1999, Final Record of Decision Idaho Nuclear Technology and Engineering Center, Operable Unit 3-13. DOE/ID-10660, Revision 0. U.S. Department of Energy Idaho Operations Office, Idaho Falls, Idaho. 
DOE-ID, 2008, “Addendum to 1995 Settlement Agreement" between the State of Idaho and the Departments of Navy and Energy. Document available at http://www.deq.state.id.us/inl_oversight/contamination/navy_addendum_2008.pdf.

DOE-ID, 2009, Mission Need Statement for the Idaho National Laboratory Remote-Handled Low-Level Waste Disposition Project, DOE/ID-11364, Idaho National Laboratory.

DOE-ID, 2011a, Acquisition Strategy for the Idaho National Laboratory Remote-Handled Low-Level Waste Disposition Project, DOE/ID-11368, Idaho National Laboratory.

DOE-ID, 2011b, Preliminary Project Execution Plan for the Remote-Handled Low-Level Waste Disposal Project, DOE/ID-11370, Idaho National Laboratory.

DOE-NR, 2008, "Disposal of Classified NRF Low Level Radioactive Waste by Burial, Approval of," Memorandum, U.S. Department of Energy Naval Reactors Laboratory Field Office, July 24, 2008.

DOE-STD-1020-02, "Natural Phenomena Hazards Design and Evaluation Criteria for Department of Energy Facilities," U.S. Department of Energy, January 2002.

DOE-STD-1021-93, "Natural Phenomena Hazards Performance Categorization Guidelines for Structures, Systems, and Components," Change 1, U.S. Department of Energy, January 1996.

DOE-STD-1027-92, "Hazard Categorization and Accident Analysis Techniques for Compliance with DOE Order 5480.23, Nuclear Safety Analysis Reports," U.S. Department of Energy, December 1992 (including Change 1, September 1997).

DOE-STD-1 189-2008, "Integration of Safety into the Design Process”, U.S. Department of Energy, March 2008.

Holdren, K. J., J. D. Burgess, K. N. Keck, D. L. Lowrey, M. J. Rohe, R. P. Smith, C. S. Staley, and J. Banaee, 1997, Preliminary Evaluation of Potential Locations on the Idaho National Engineering and Environmental Laboratory for a High-Level Waste Treatment and Interim Storage Facility and a Low-Level Waste Landfill, INEEL/EXT-97-01324, Revision 0. Lockheed Martin, Idaho Falls, Idaho.

IAEA, Draft IAEA Safety Standards for protecting people and the environment, Near Surface Disposal of Radioactive Waste, Draft Safety Guide, DS 356, International Atomic Energy Agency.

IAEA, 1999, IAEA Safety Standards Series, Near Surface Disposal of Radioactive Waste, Requirements, No. WS-R-1, International Atomic Energy Agency, June 1999.

IAEA, 2006, IAEA Safety Standards for protecting people and the environment, Fundamental Safety Principles, Safety Fundamentals, No. SF-1, International Atomic Energy Agency, November 2006.

IBC, 2009, International Building Code, International Code Council.

IDAPA 18, Title 01, Chapter 50, “Adoption of the International Fire Code," 2003, Idaho Administrative Procedures Act, Idaho Department of Environmental Quality, April 6, 2005. 
IDAPA 58, Title 01, Chapter 01, "Rules for the Control of Air Pollution in Idaho," Idaho Administrative Procedures Act, Idaho Department of Environmental Quality, July 1, 2007.

IDAPA 58, Title 01, Chapter 01, Section 201, "Permit to Construct Required," Idaho Administrative Procedures Act, Idaho Department of Environmental Quality, April 11, 2006.

IDAPA 58, Title 01, Chapter 01, Section 202, “Application Procedures,” Idaho Administrative Procedures Act, Idaho Department of Environmental Quality, July 1, 2002.

IDAPA 58, Title 01, Chapter 03, “Individual/Subsurface Sewage Disposal Rules,” Idaho Administrative Procedures Act, Idaho Department of Environmental Quality, 2009.

IDAPA 58, Title 01, Chapter 03, Section 005, "Permit and Permit Application," Idaho Administrative Procedures Act, Idaho Department of Environmental Quality, 2009.

IDAPA 58, Title 01, Chapter 06, "Solid Waste Management Rules," Idaho Administrative Procedures Act, Idaho Department of Environmental Quality, 2009.

IDAPA 58, Title 01, Chapter 08, "Idaho Rules for Public Water Drinking Systems," Idaho Administrative Procedures Act, Idaho Department of Environmental Quality, 2003.

IDAPA 58, Title 01, Chapter 08, Section 550, "Reserved," Idaho Administrative Procedures Act, Idaho Department of Environmental Quality, 2003.

IDAPA 58, Title 01, Chapter 17, "Rules for Owners and Operators of Underground Storage Tanks and Leaking Petroleum Storage Tanks," Idaho Administrative Procedures Act, Idaho Department of Environmental Quality, April 11, 2006.

IEEE-STD-141, "IEEE Recommended Practice for Electric Power Distribution for Industrial Plants," July 23, 1997.

IEEE-STD-242, "IEEE Recommended Practice for Protection and Coordination of Industrial and Commercial Power Systems," 2001.

INL, 2010a, Safety Design Strategy for the Remote-Handled Low-Level Waste Disposal Project, INL/EXT-09-17117, Idaho National Laboratory.

INL, 2010b, Conceptual Safety Design Report for the Remote-Handled Low-Level Waste Disposal Project, INL/EXT-09-17427, Idaho National Laboratory.

INL, 2010c, Siting Study for the Remote-Handled Low-Level Waste Disposal Project, INL/EXT-07-12902, Idaho National Laboratory.

INL, 2011, Remote-Handled Low-Level Waste Disposal Project Alternatives Analysis, INL/EXT-09-17152, Idaho National Laboratory.

LWP-7201, “INL Construction,” Idaho National Laboratory.

LWP-7350, “Project Risk Management,” Idaho National Laboratory.

LWP-9902, "Startup and Restart of Nuclear Facilities," Idaho National Laboratory. 
LWP-9903, "Performing Management Self-Assessments for Readiness," Idaho National Laboratory.

LWP-13014, “Determining Quality Levels,” Idaho National Laboratory.

NFPA 70, "National Electrical Code," National Fire Protection Association, 2005.

NFPA 101, "Life Safety Code,” National Fire Protection Association, 2006.

NS-18101, "INL Safety Analysis Process,” Idaho National Laboratory.

NUREG-0945, “Final Environmental Impact Statement on 10 CFR 61,” U.S. Regulatory Commission, Office of Nuclear Regulatory Research, Washington, D.C., November 1982.

PL 99-499, 1986, "Superfund Amendments and Reauthorization Act of 1986 (SARA)," 100 Statutes 1728, Public Law, October 17, 1986.

PLN-2541, "Risk Management Plan for the Remote-Handled Low-Level Waste Disposal Facility Project," Idaho National Laboratory.

PLN-3359, "Quality Assurance Program Plan for the Remote-Handled Low Level Waste Disposal Project," Idaho National Laboratory.

STD-139, "INL Engineering Standards," Idaho National Laboratory.

Spry, M. J., K. S. Moor, S. J. Maheras, and H. K. Peterson, 1989, Site Selection Report for the New Production Reactor at the Idaho National Engineering Laboratory, EGG-NPR-8517, Revision 1, EG\&G Idaho, Inc.

Taylor, D. D., R. L. Hoskinson, C. O. Kingsford, and L. W. Ball, 1994, Preliminary Siting Activities for New Waste Handling Facilities at the Idaho National Engineering Laboratory, EGG-WM-11118, EG\&G Idaho, Inc.

TFR-483, "Remote-Handled Low-Level Waste Disposal Facility Technical and Functional Requirements," Idaho National Laboratory. 
Appendix A

\section{Conceptual Design Drawings}




$$
\text { A-2 }
$$




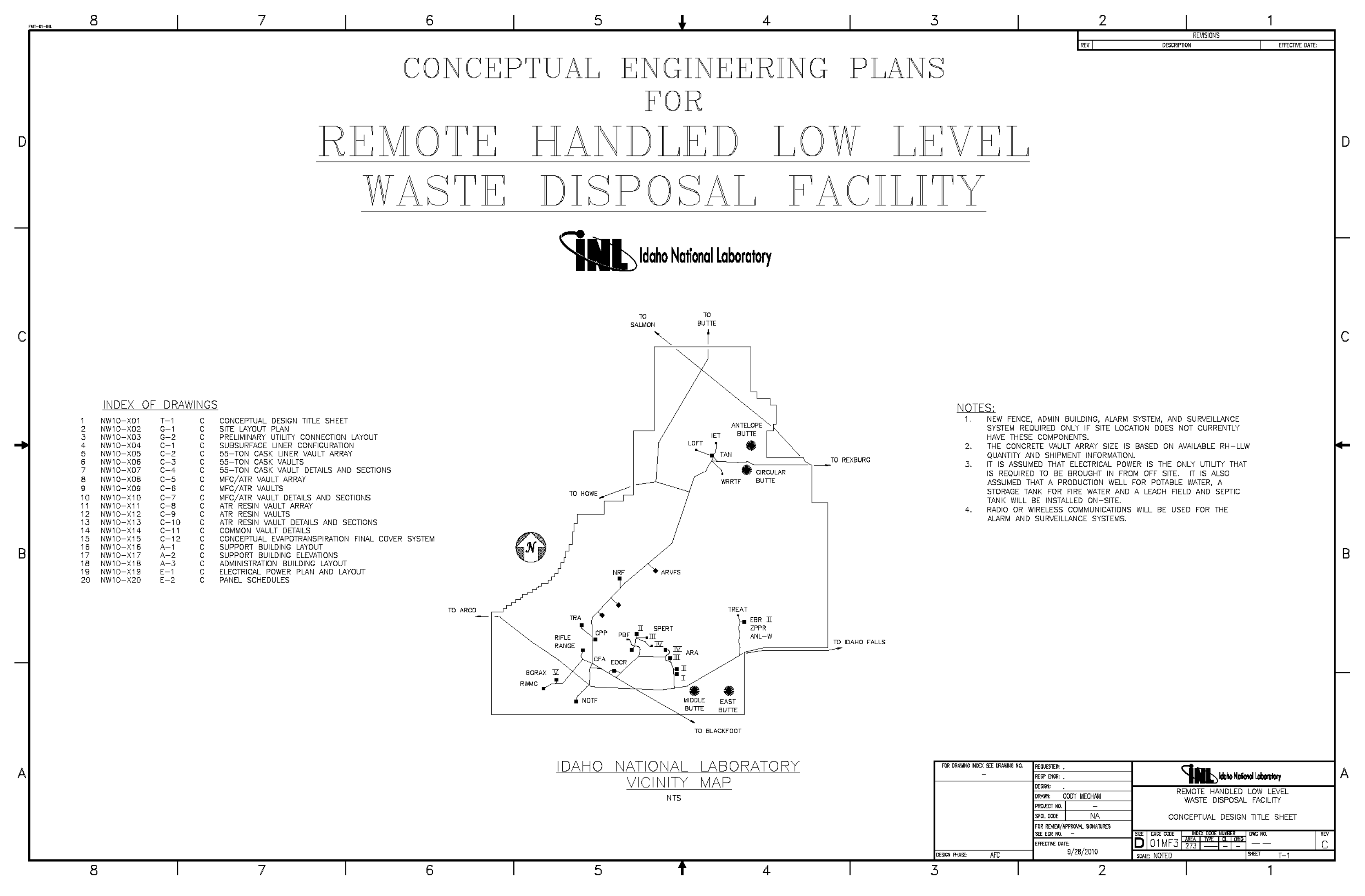




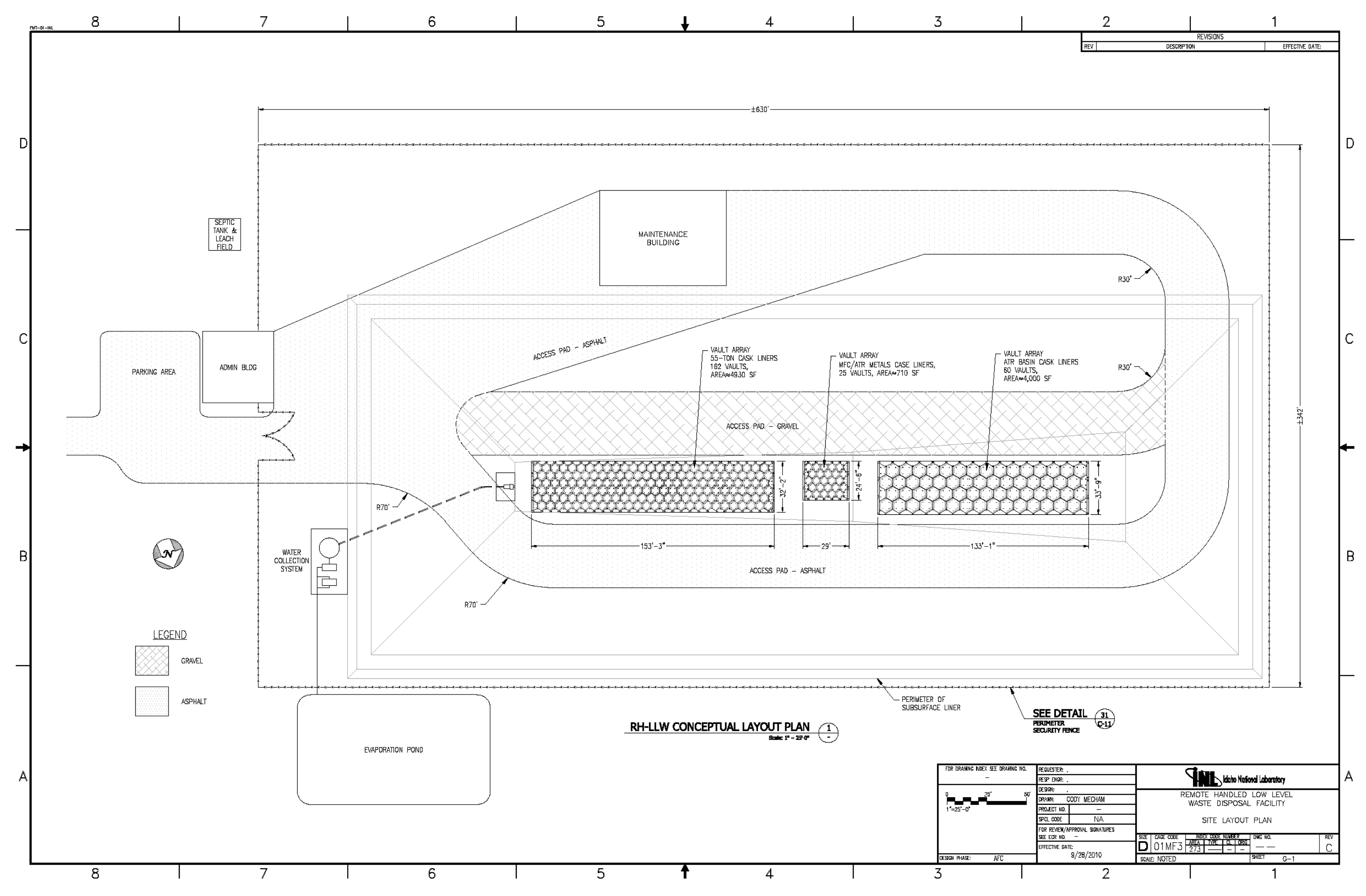




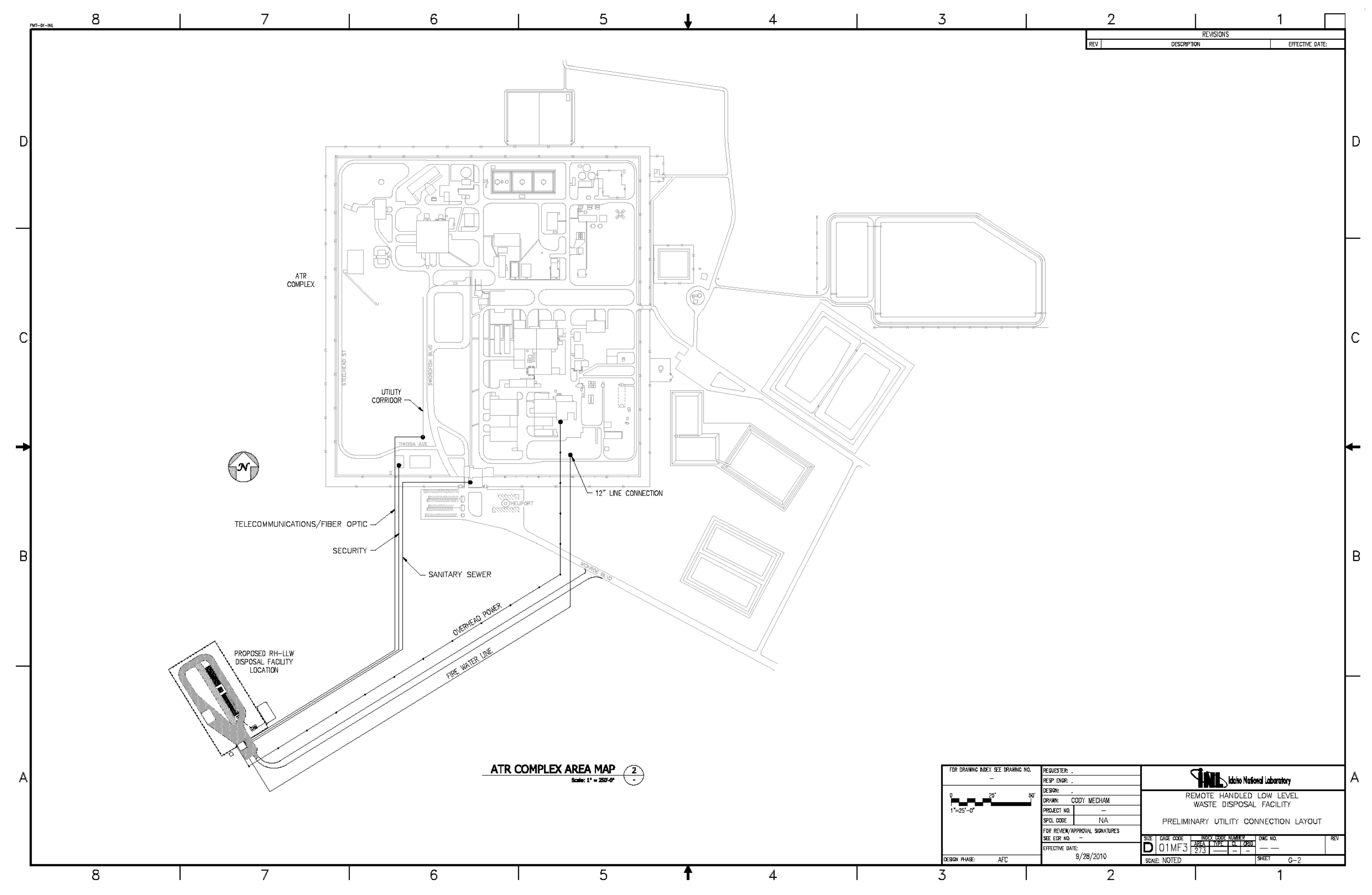




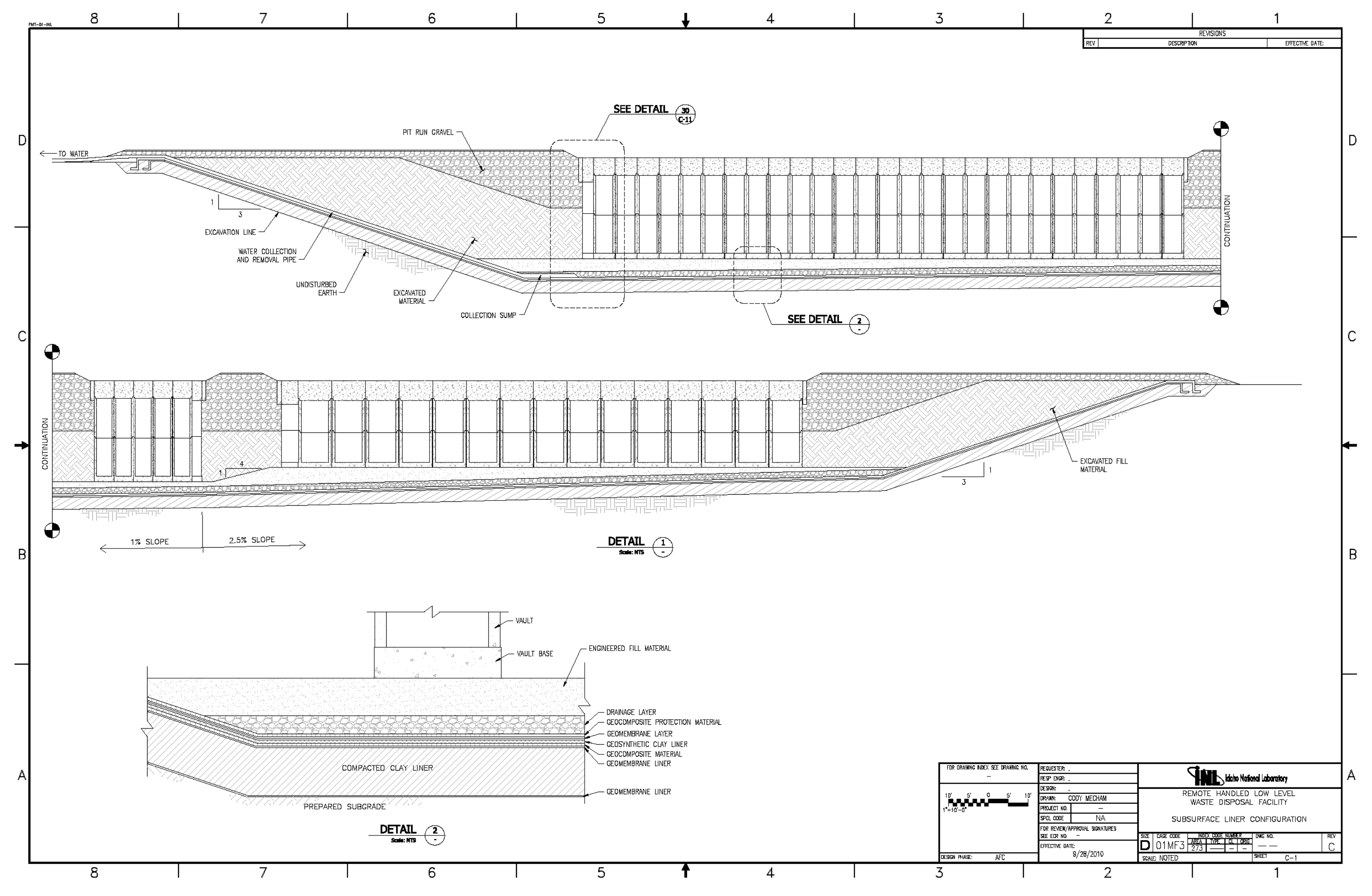




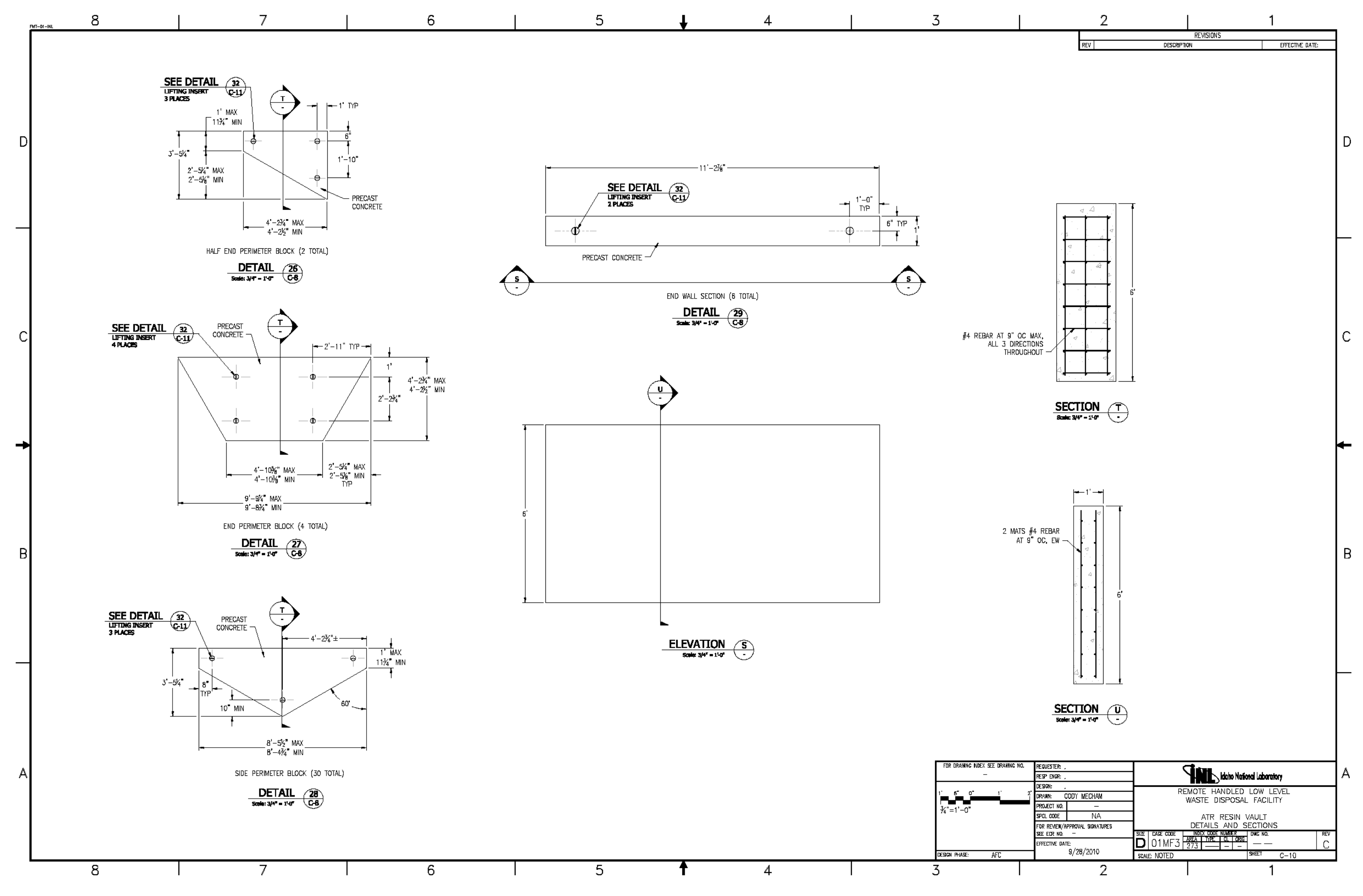




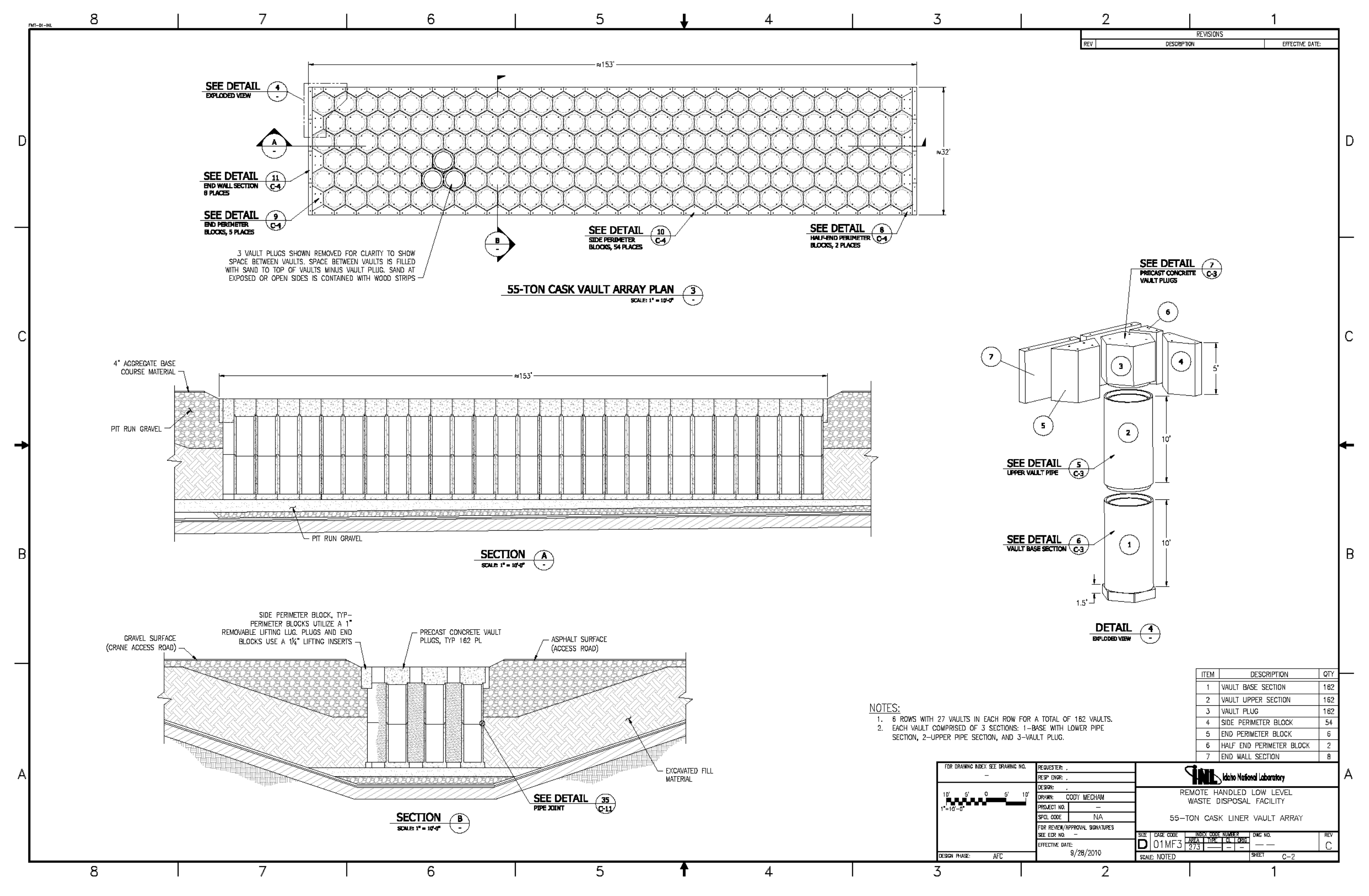




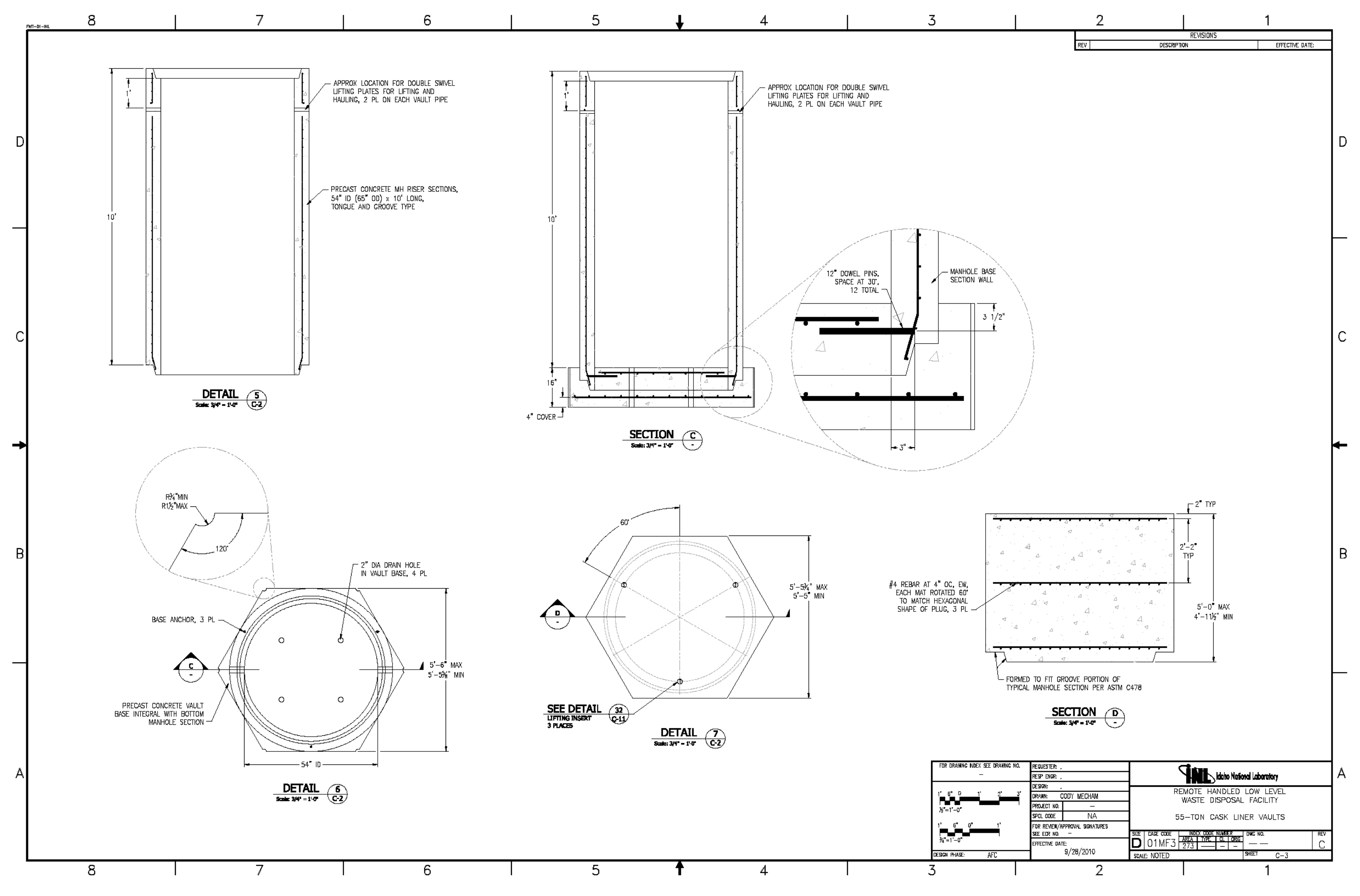




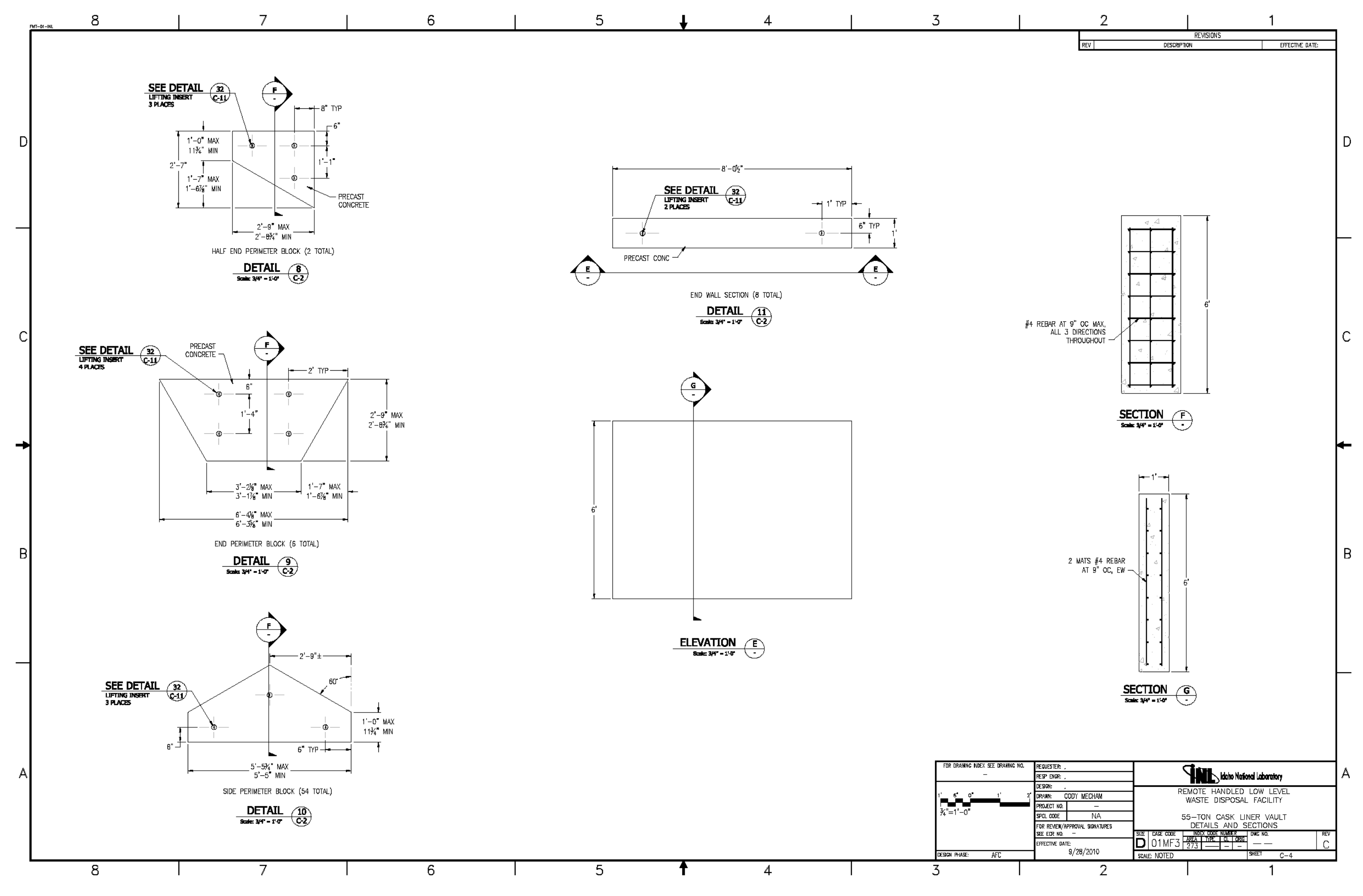




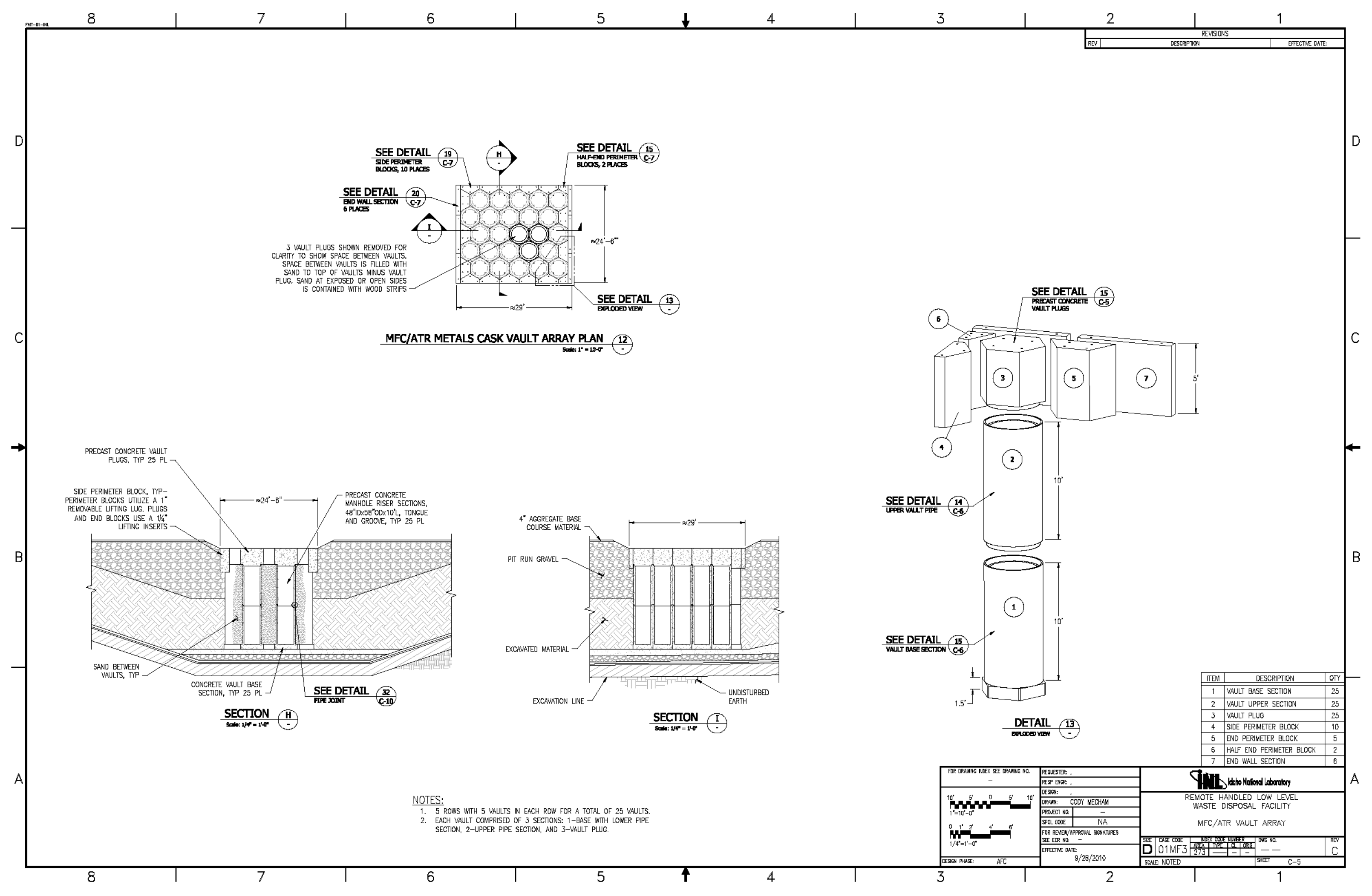




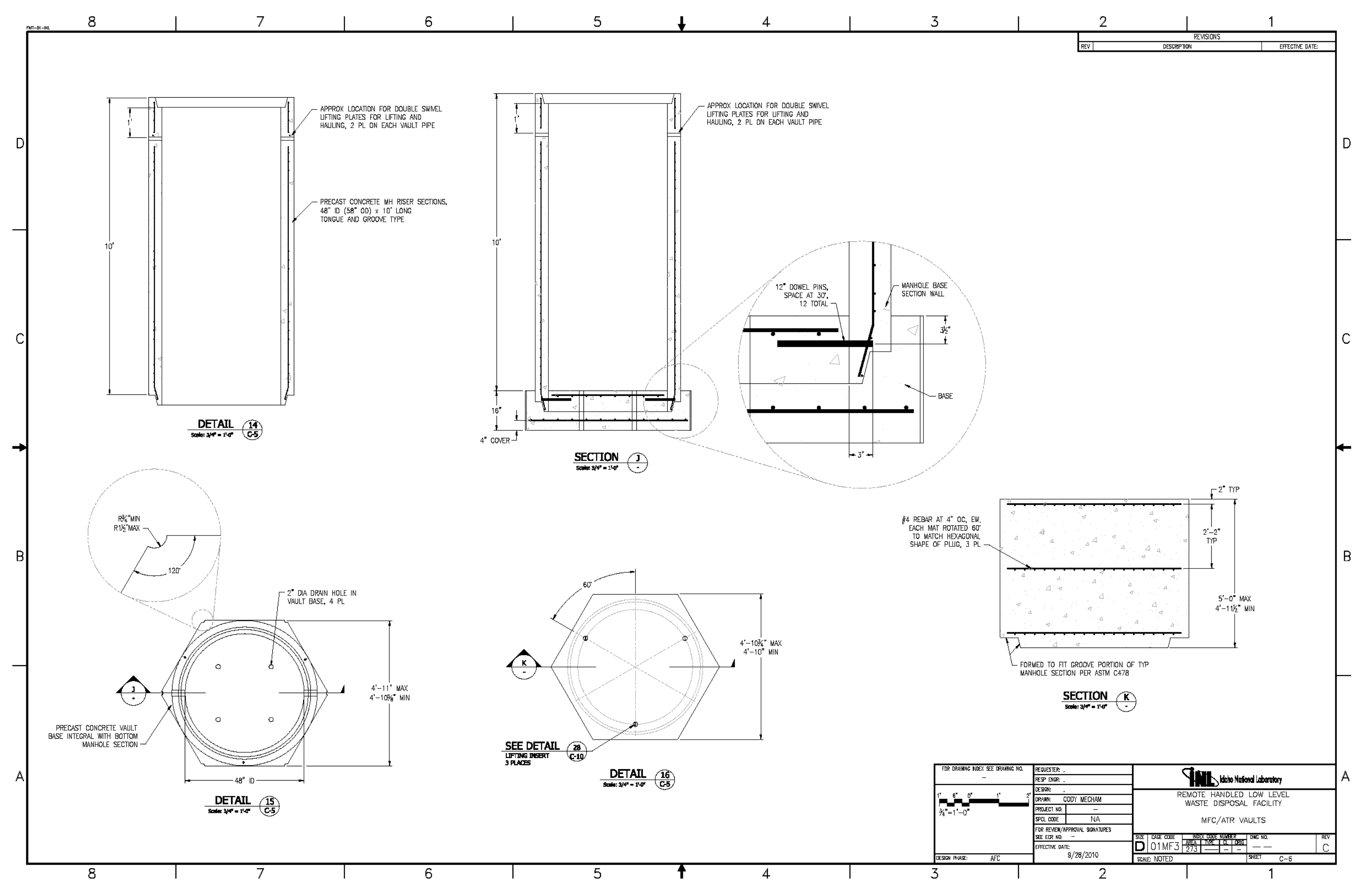




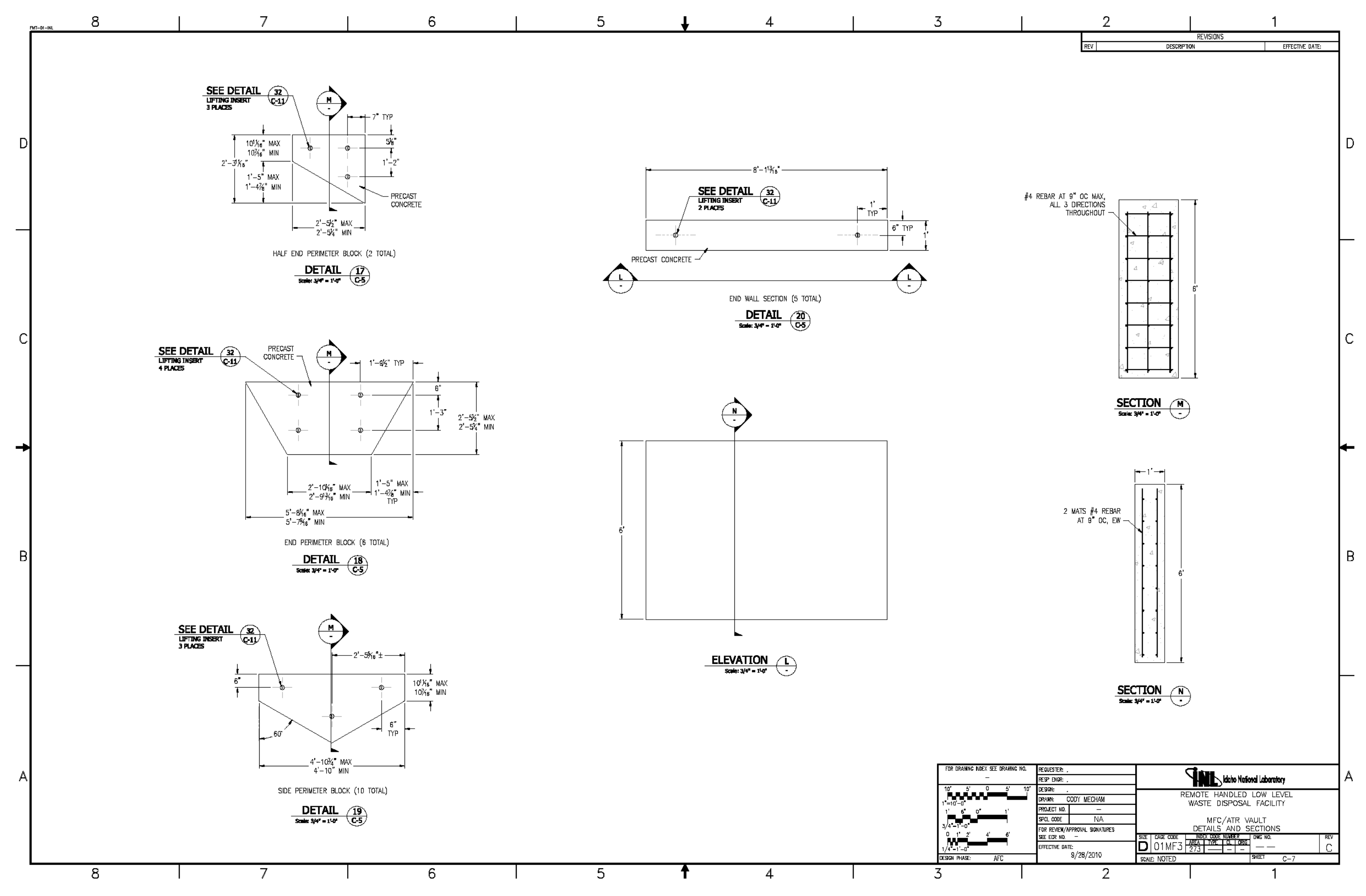




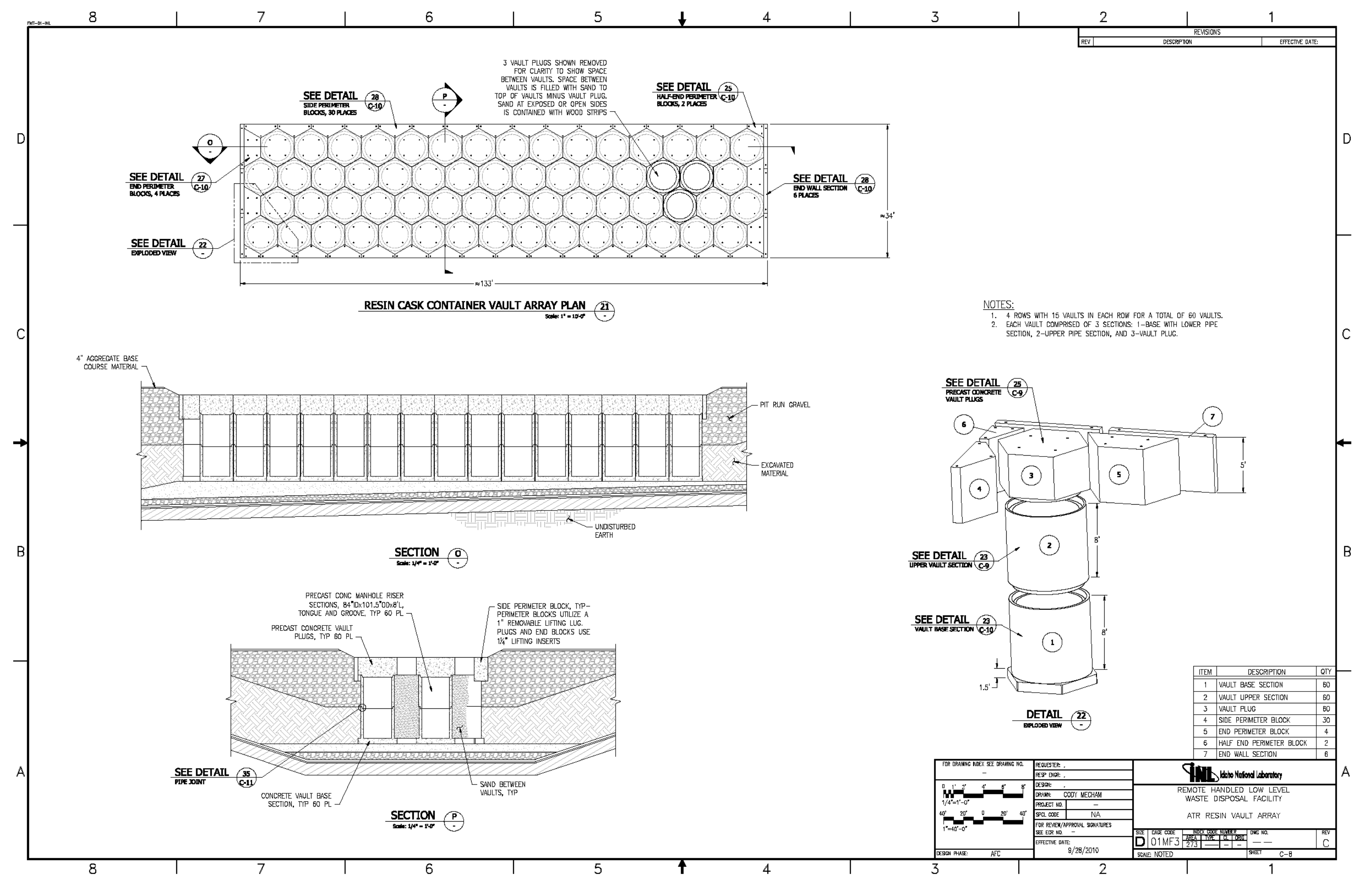




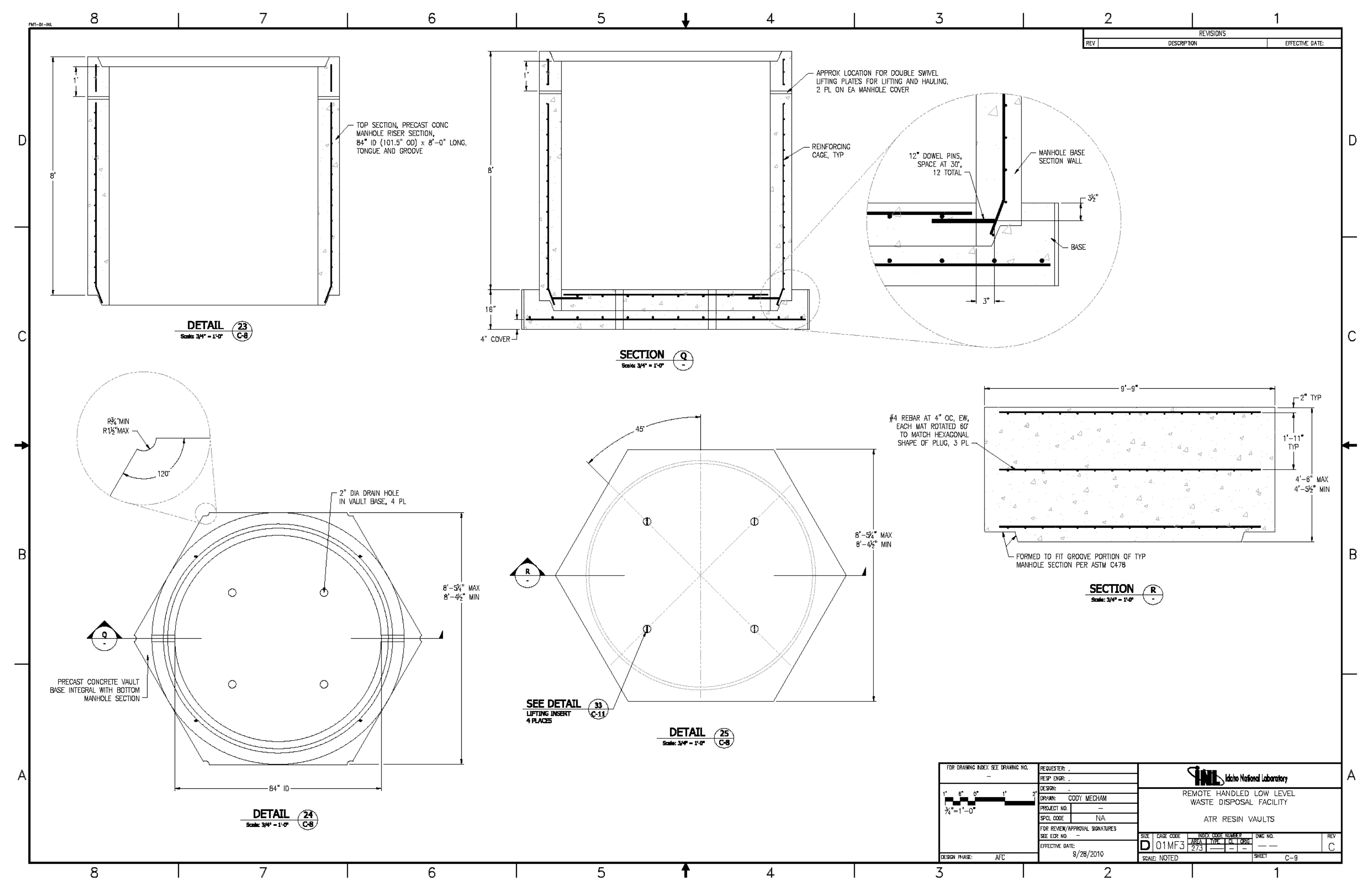




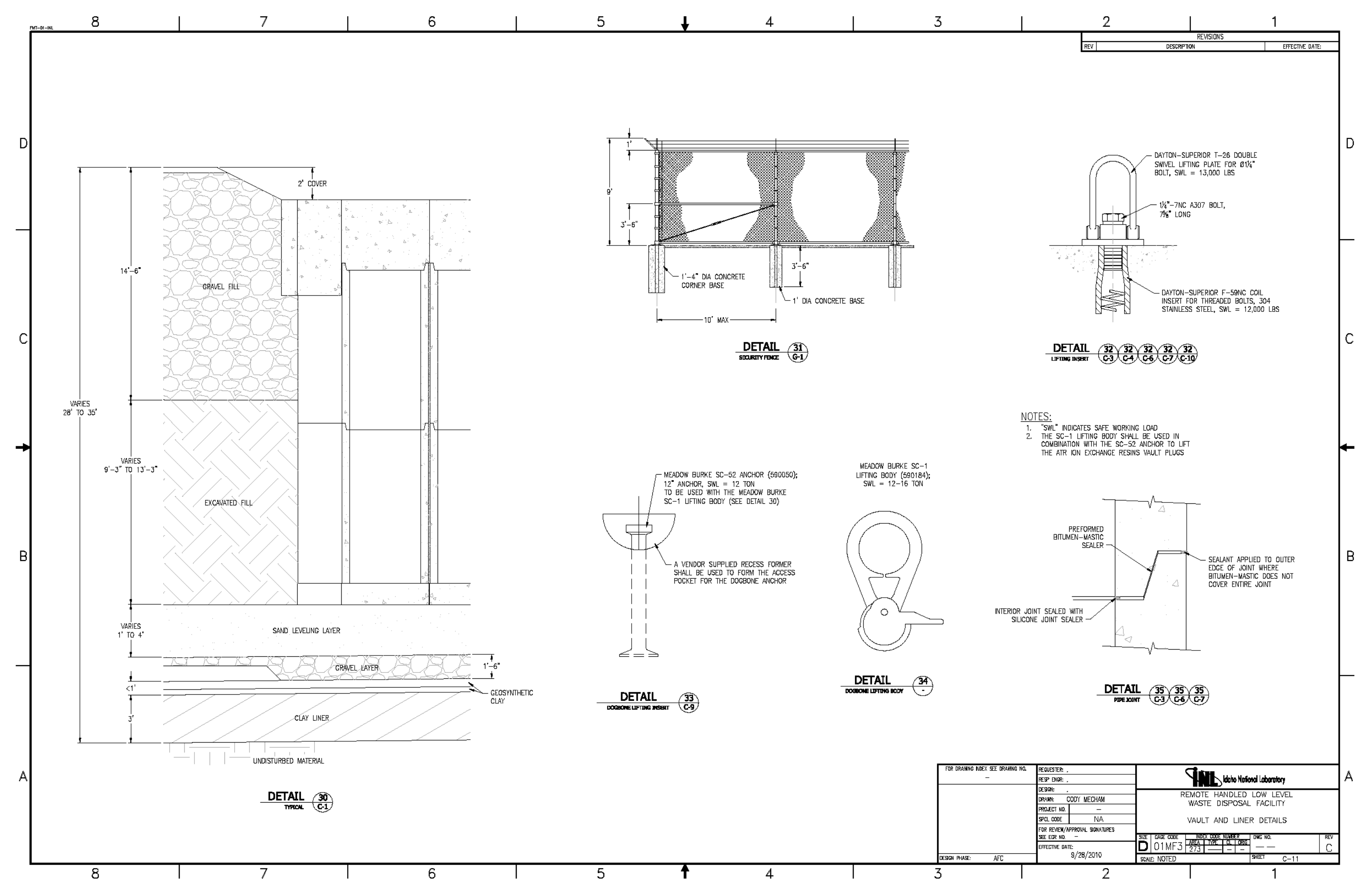




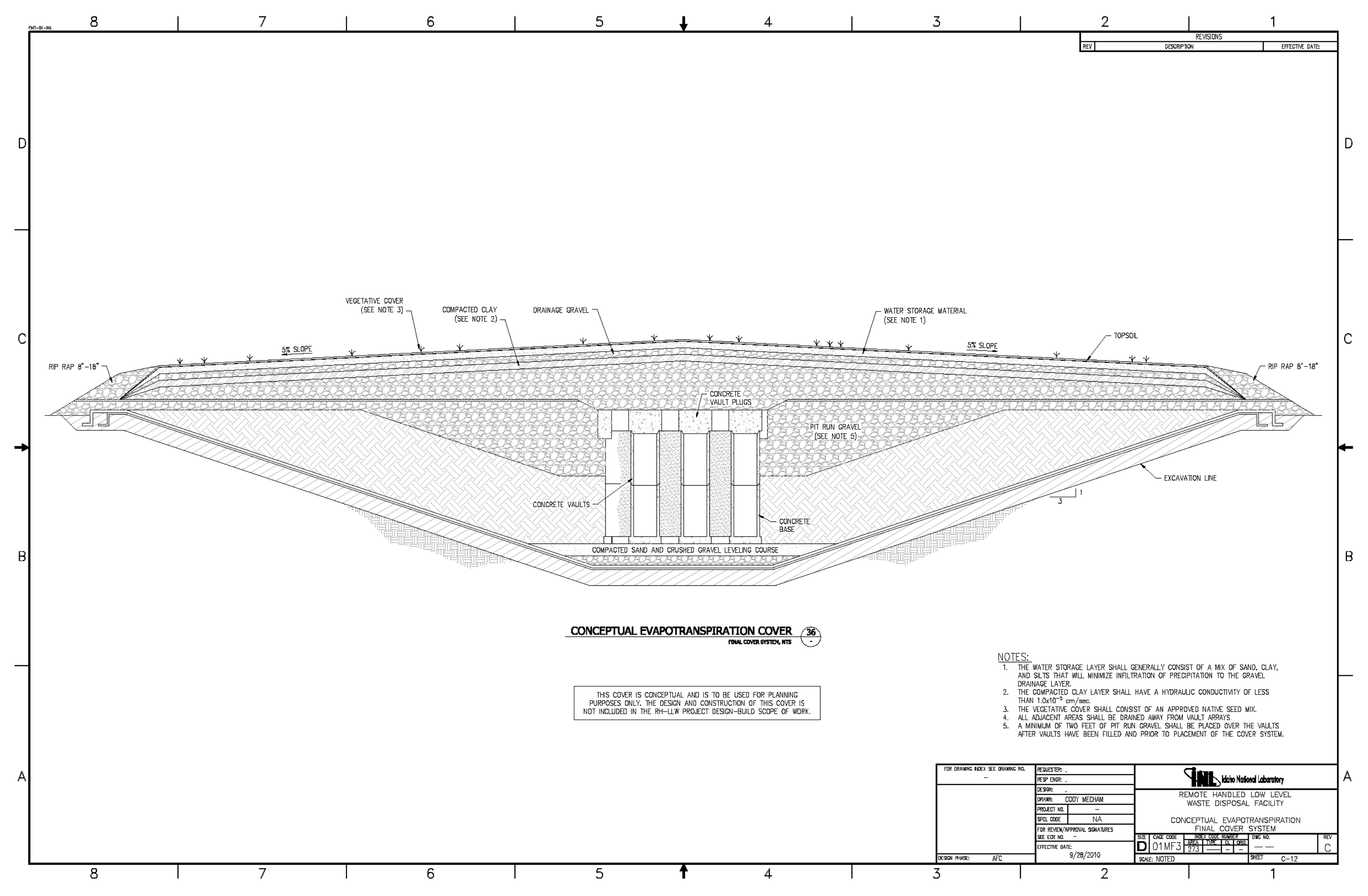




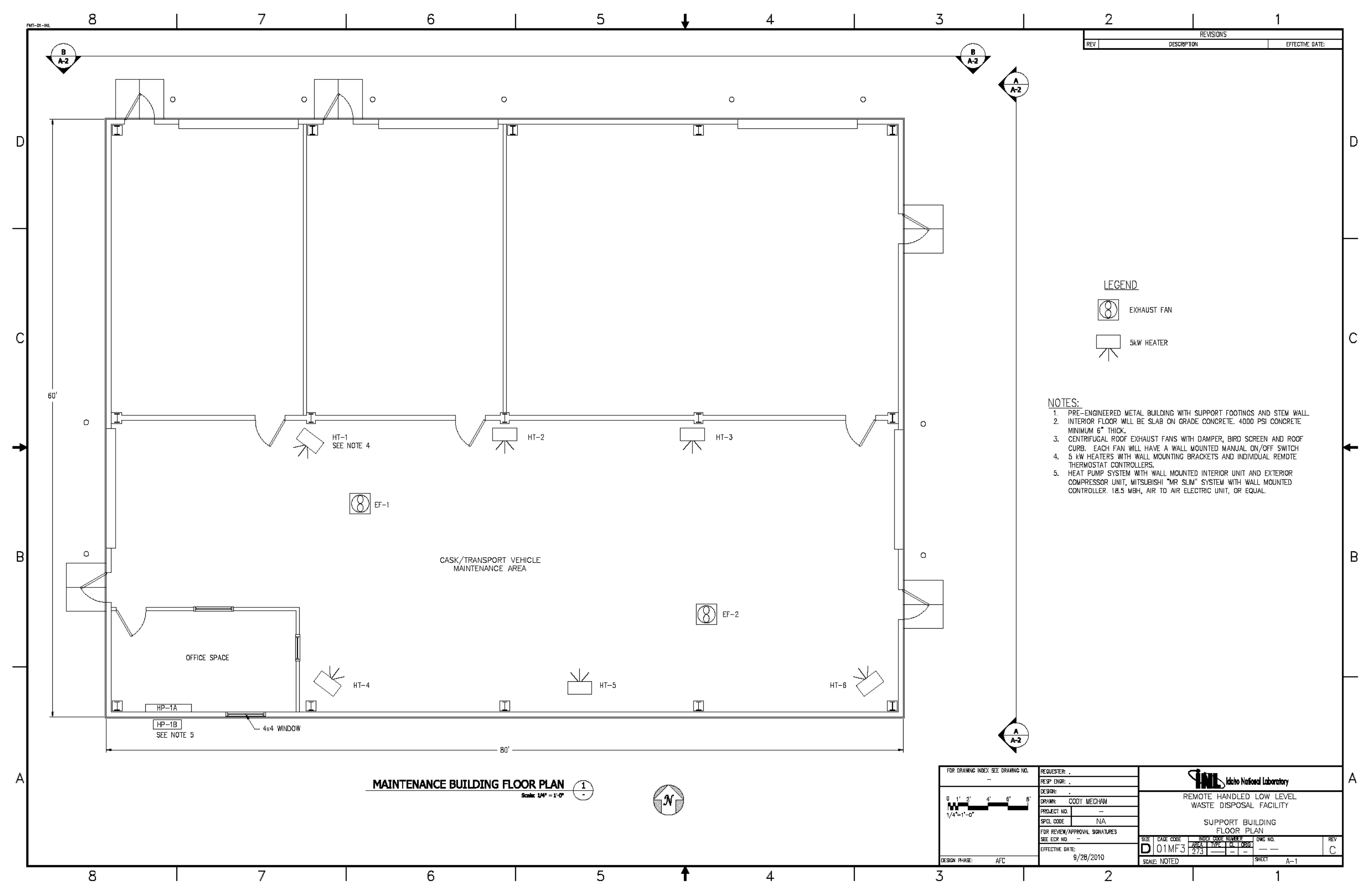




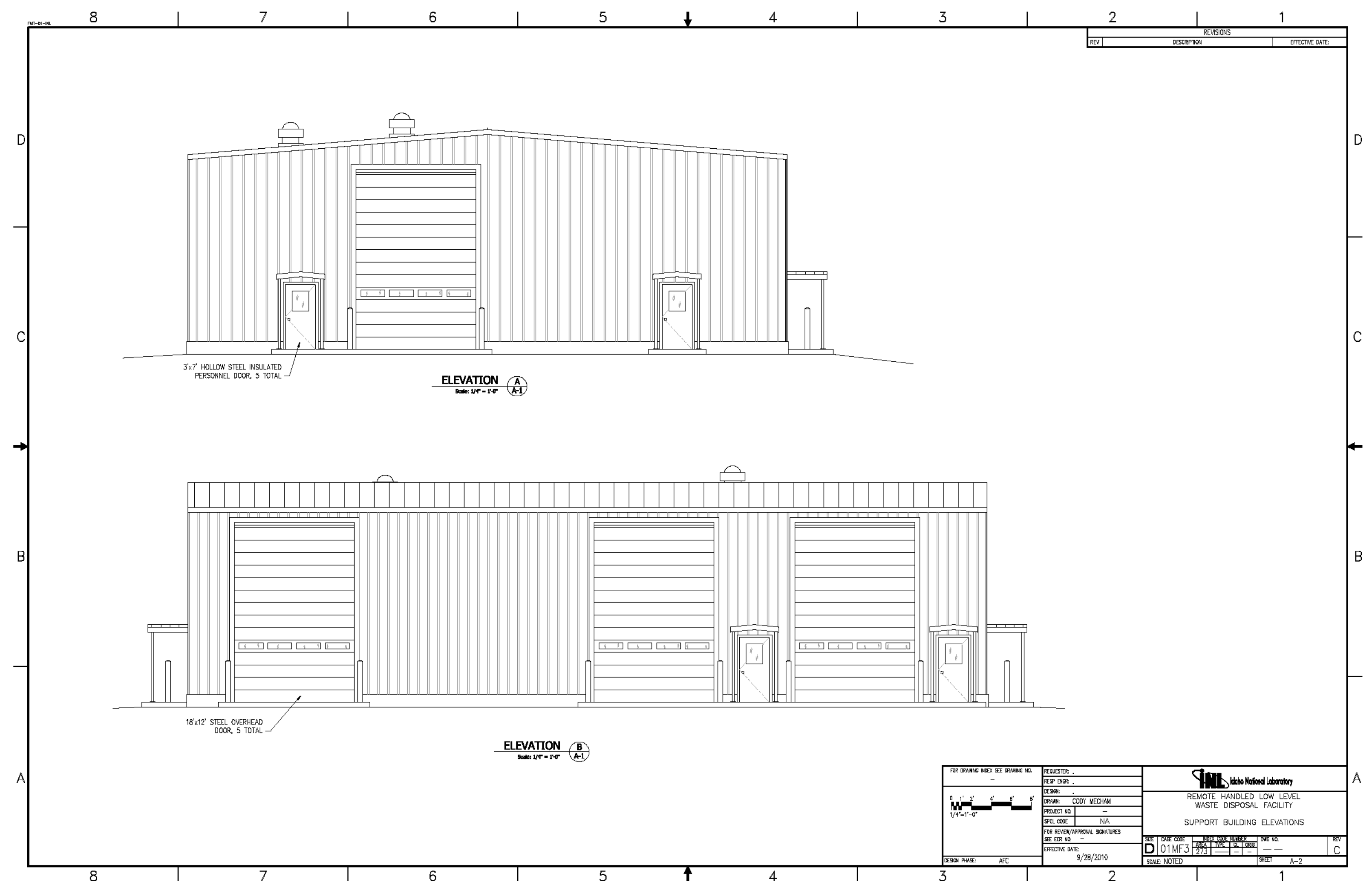




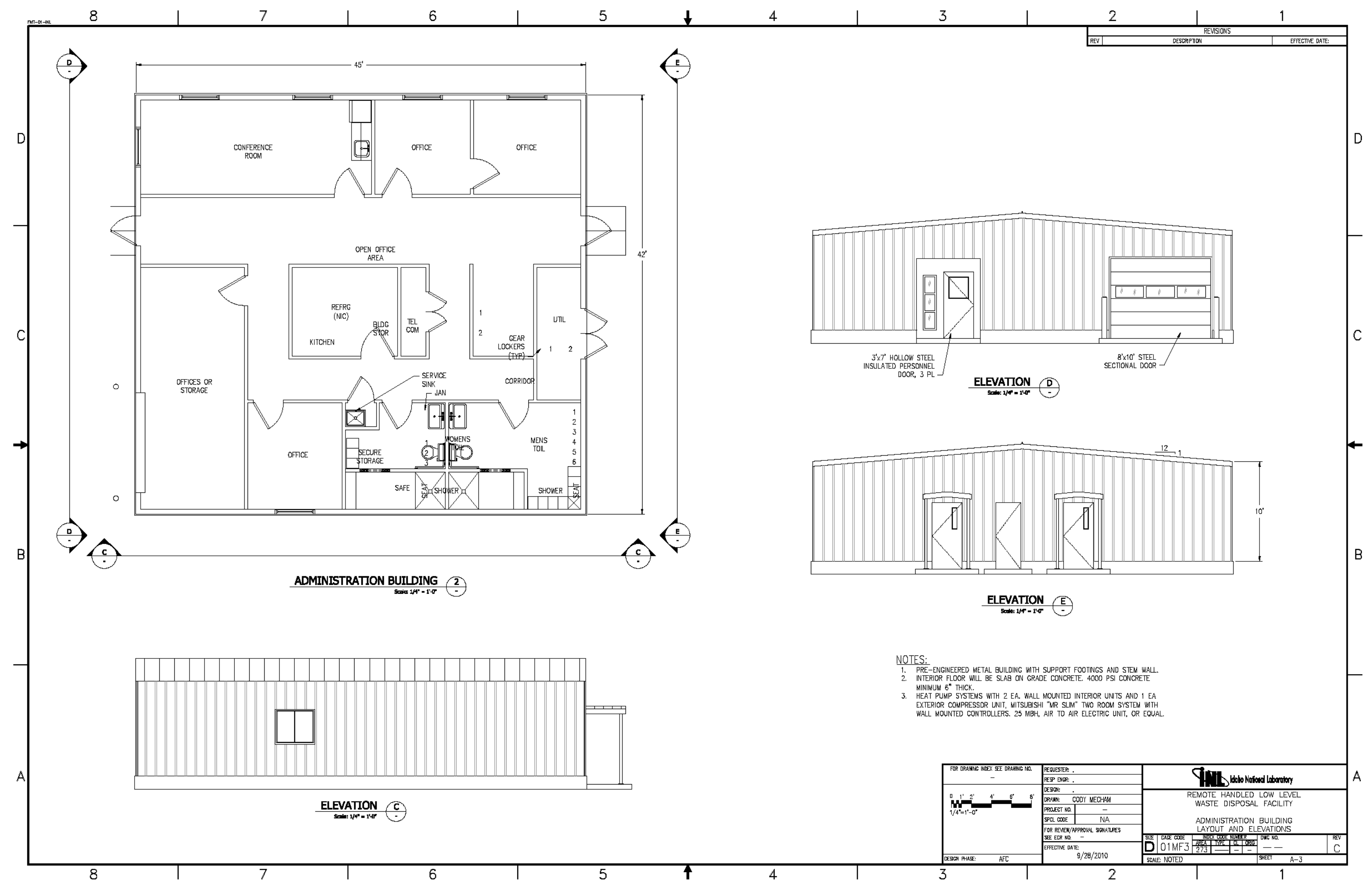




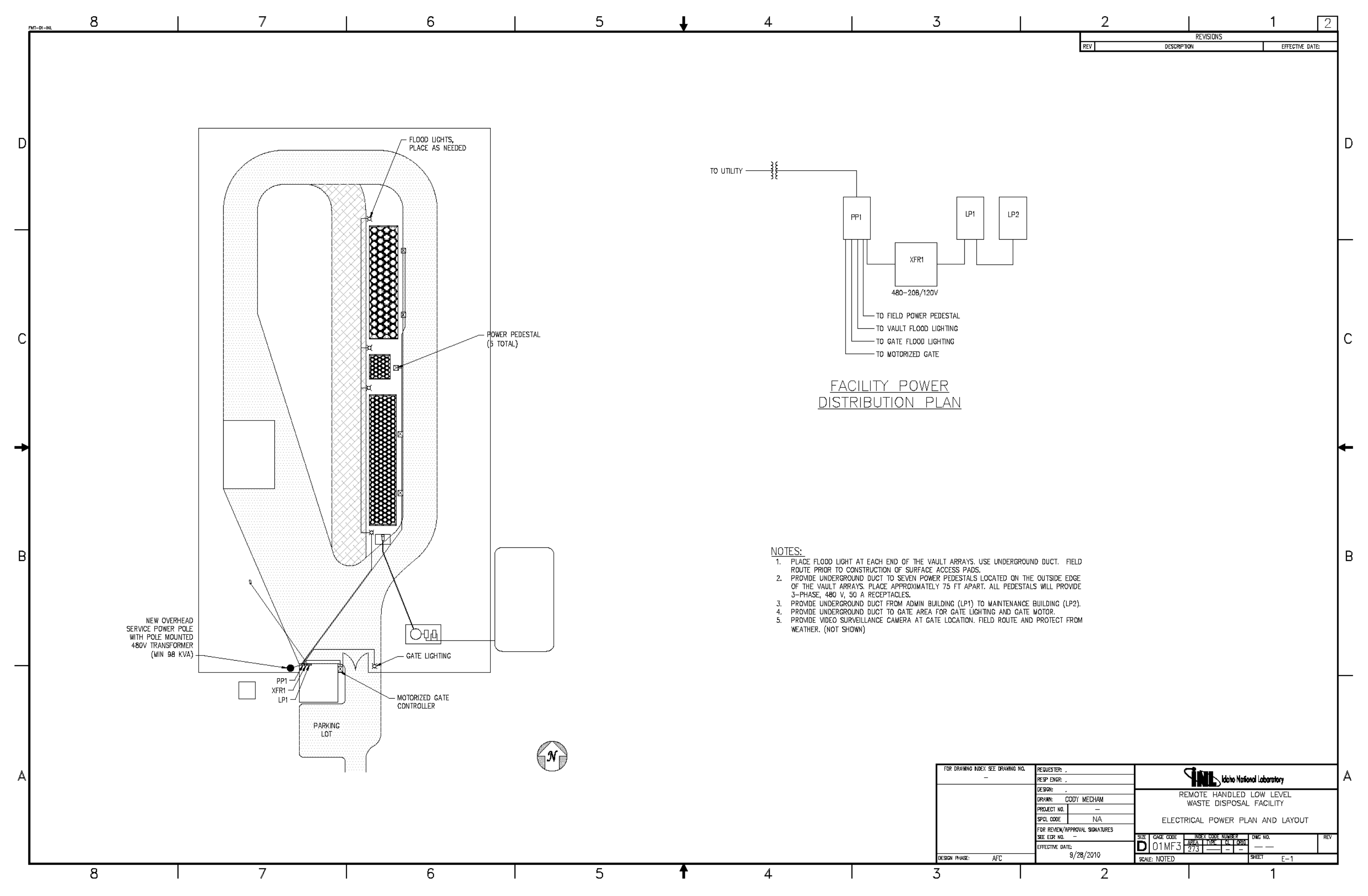




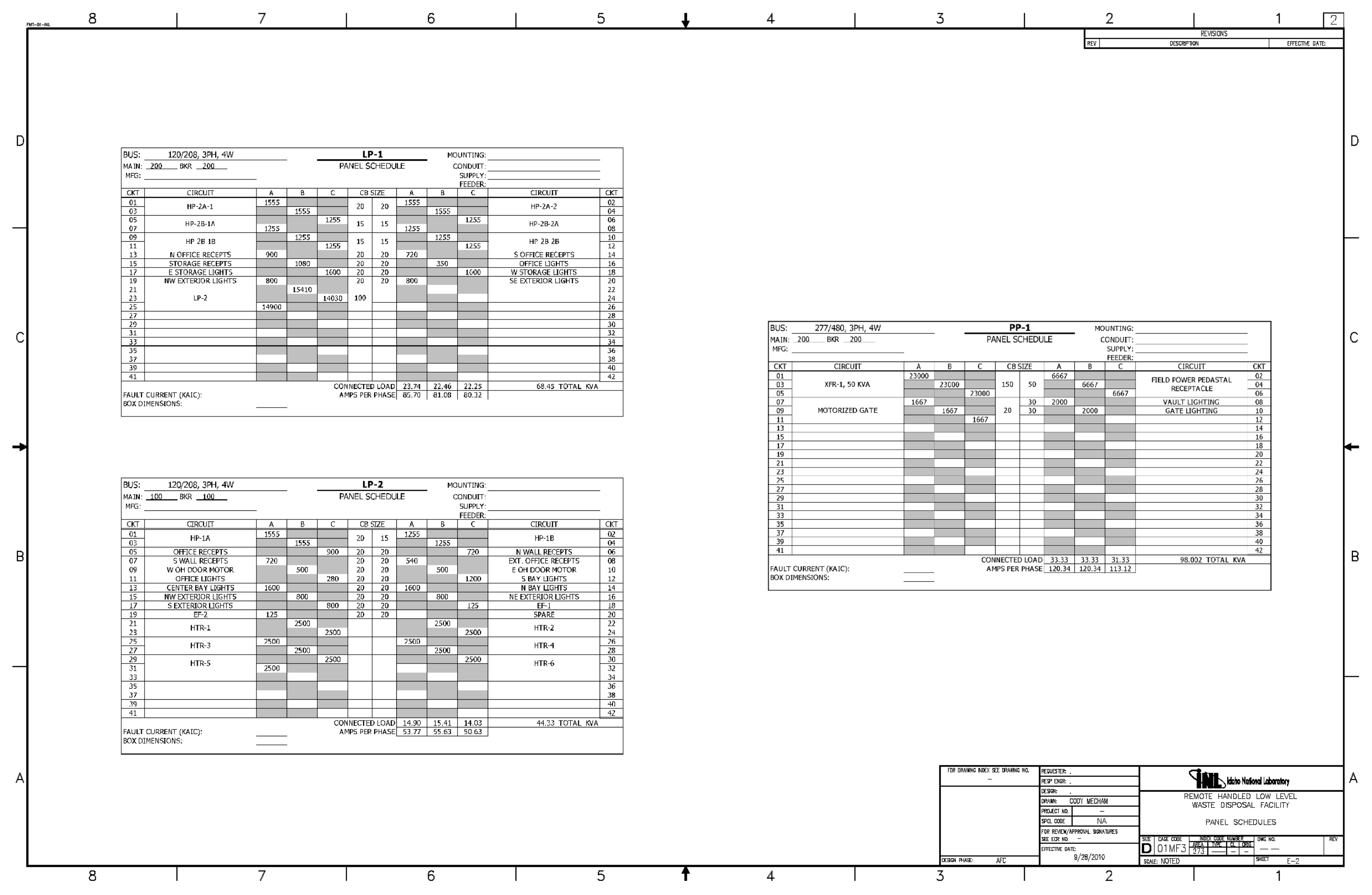


Appendix B

Sustainability Design Report 
B-2 


\section{Appendix B}

\section{Sustainability Design Report}

The project was evaluated against the High Performance Sustainable Building (HPSB) principles outlined in DOE G 413.3-6, "High Performance Sustainable Building." The majority of the proposed project facility costs are associated with the design and construction of the remote-handled LLW disposal vaults, which due to the function and purpose of these structures would not be susceptible to incorporation of the HPSB principles. The portion of the project in which the HPSB principles would apply is related to the design and construction of the administrative building and the maintenance building.

The HPSB principles address goals and configuration elements from the following five areas:

1. Employ integrated design principles

2. Optimize energy performance

3. Protect and conserve water

4. Enhance indoor environmental quality

5. Reduce environmental impact of construction materials.

The associated project buildings are envisioned to be relatively simple pre-engineered metal buildings that will be used on a periodic basis to support the waste container disposal operations. The administrative building is estimated to have a footprint of approximately $900 \mathrm{ft}^{2}\left(84 \mathrm{~m}^{2}\right)$ and be used for a small administrative office and small equipment and records storage. The actual occupancy level for this building is expected to be very low. The maintenance building is estimated to be approximately $1,800 \mathrm{ft}^{2}$ $\left(167 \mathrm{~m}^{2}\right)$ and will be used primarily as an equipment storage area.

To address the HPSB principles, an initial review of the LEED rating system was completed. As stated in the HPSB guidance, the LEED rating system can be used to evaluate conformance with the HPSB principles. The results are shown in the attached LEED NC Checklist. Because of the low occupancy rates, small building area to project area ratio, and the probable facility location being away from urban or populated areas, it is not likely that the project buildings will be able to obtain a certification level per the LEED requirements. However, this evaluation does identify the HPSB and LEED criteria that most likely can be incorporated into the building designs in order to construct practical, energy efficient, and high performing sustainable buildings as appropriate for this project. Details on how the applicable LEED criteria would be incorporated into the building design will be evaluated and incorporated into the final design phase of the project. 


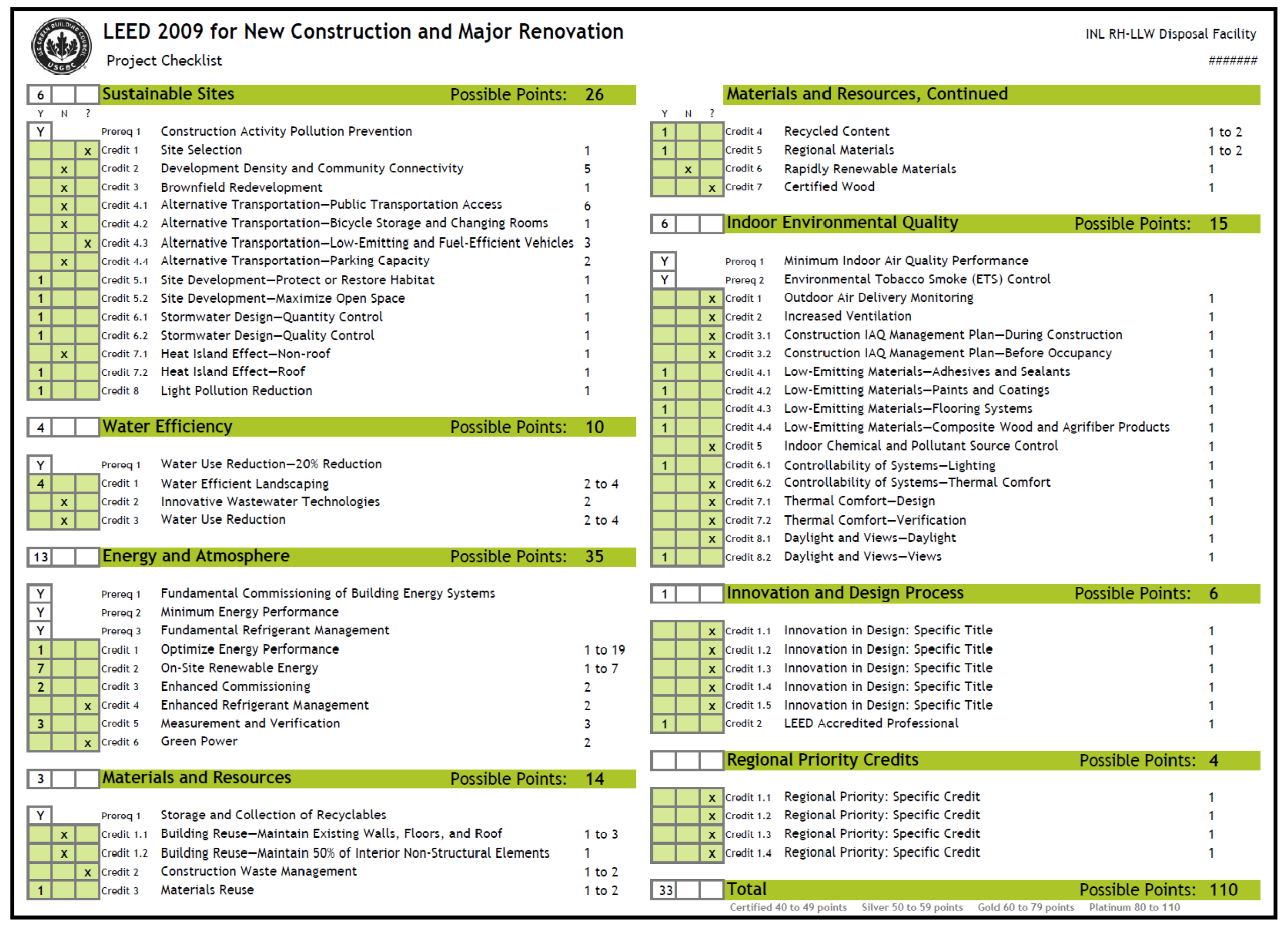


Appendix C

\section{Engineering Design Review}




$$
\text { C-2 }
$$




\section{Appendix C \\ Engineering Design Review}

\section{North Wind}

Review Comments and Resolutions

\begin{tabular}{|l|l|l|l|l|}
\hline $\begin{array}{l}\text { Reviewer's Name: } \\
\text { Brent Harris'Stephanie Austad }\end{array}$ & $\begin{array}{l}\text { Date Reviewed: } \\
01 / 2008 \text { and } \\
10 / 2009\end{array}$ & Retum Comments To: & Comments Due \\
By.
\end{tabular}

"Comm ents so marked are considered to be sigrificant and must be resolved to the reviewer's satisfaction Sigrificant comment, A reviewer's written response that is derived from the reviewer's area of expertise, discipline, of that addresses material assigning tasks to the revie wer's organization. Sigrificant com ments address's issues of A: noncompliance with 1aws, regulations, permit standards, or contract B: proper conduct of mission critical operations C: creating uns afe conditions that could result in personal injury, death, of damage to the envir onment D: creating conditions that could result in sigrificant nonessential costs to the

\begin{tabular}{|c|c|c|c|c|c|}
\hline \multicolumn{2}{|c|}{ Document ID: } & \multicolumn{2}{|r|}{$\begin{array}{l}\text { Document Title: } \\
\text { RH LLW Engineering Design Review (1/16/2008) }\end{array}$} & \multirow{2}{*}{\multicolumn{2}{|c|}{\begin{tabular}{|c|c|} 
Revision ID: & DC Number: \\
Comment Resolution***
\end{tabular}}} \\
\hline Item No. & Page No.Section & * & Review Comment & & \\
\hline 1. & $\begin{array}{l}\text { CDR } \\
4-9 / 4.5 .3 \\
\text { Brent H. }\end{array}$ & & Capacity? (In reference to crane cap acity) (1/2008) & $\begin{array}{l}\text { Comment } \\
\text { now reads: } \\
\text { mobile two } \\
\text { total weigh } \\
(118,943 \mathrm{k} \\
\text { capacity of } \\
\text { tons }(127,0\end{array}$ & $\begin{array}{l}\text { pted; The text } \\
\text { his crane is a } \\
\text { ck crane with a } \\
262,225 \mathrm{lb} \\
\text { and a lifting } \\
\text { oroximately } 140 \\
\text { kg)." }\end{array}$ \\
\hline 2. & $\begin{array}{l}\text { CDR } \\
\text { Section } 7.2 \\
\text { Last sentence } \\
\text { Stephanie A. }\end{array}$ & & $\begin{array}{l}\text { Should Group be Occupancy Category per IBC table } 1604 \text {.5? It would seem that for } \\
\text { a Haz Cat II facility, an Occupancy Category I would be a little low. I would not } \\
\text { group a nuclear facility with agricultural and temporary buildings (having a lower } \\
\text { design criteria than a normal office building). I would consider Occupancy Category } \\
\text { II a minimum for a permanent facility. Please expand this section and address the non- } \\
\text { nuclear support buildings, as well. Section } 4.5 .3 \text { also references Group I. (10/5/09) }\end{array}$ & $\begin{array}{l}\text { Reference } \\
\text { was remov } \\
\text { refering to } \\
\text { not have ar } \\
\text { applicable } \\
\text { required fo } \\
\text { to be evalu } \\
\text { next phase } \\
\text { was added } \\
\text { building oo }\end{array}$ & $\begin{array}{l}\text { Group I facility } \\
\text { The text is } \\
\text { vaults which will } \\
\text { ccupancy. The } \\
\text { mic analysis } \\
\text { e vaults will need } \\
\text { das part of the } \\
\text { ign efforts. Text } \\
\text { address the admin } \\
\text { ancy category. }\end{array}$ \\
\hline 3. & $\begin{array}{l}\text { TFR } \\
14 / 3 \cdot 1.2 .7 \& 8 \\
\text { Stephanie A. }\end{array}$ & & $\begin{array}{l}\text { The basis for potable and sewer should be the sanitay requirements from OSHA and } \\
\text { the IBC. I'd be interested in the cost of the potable well. You could be looking at } \\
\text { anywhere between } 200 \mathrm{~K} \text { and } 500 \mathrm{~K} \text { for just the well. (1/2008) }\end{array}$ & $\begin{array}{l}\text { Anticipatec } \\
\text { occupancy } \\
\text { LLW do no }\end{array}$ & $\begin{array}{l}\text { affing and } \\
\text { els at the } \mathrm{RH} \\
\text { equire potable }\end{array}$ \\
\hline
\end{tabular}

QAF-061.2 Rev.4 Effective 03/07/07 


\section{North Wind}

Review Comments and Resolutions

\begin{tabular}{|c|c|c|c|}
\hline & & & $\begin{array}{l}\text { water or sewer systems based } \\
\text { on OSHA or IBC requirements. } \\
\text { However, these systems were } \\
\text { included in the preliminary } \\
\text { design pending future } \\
\text { discussion. }\end{array}$ \\
\hline 4. & $\begin{array}{l}\text { TFR } \\
\text { Section } 2.2 \\
\text { Stephanie A. }\end{array}$ & $\begin{array}{l}\text { If you are applying STD-1189 to this job, I don't think youll reference a performance } \\
\text { category. You'll need to determine Seismic Design Category from STD-1 } 189 \text { and } \\
\text { from ANS } 2.26 \text { Appendix B you'll determine your Limit State. This requirement is } \\
\text { worded better in section } 7.2 \text { of the CDR. What's the status of DOE-1189 } \\
\text { implementation? (10/5/09) }\end{array}$ & $\begin{array}{l}\text { The text from the CDR was } \\
\text { incoporportaed into this } \\
\text { section. DOE O } 1189 \text { will be } \\
\text { incorportaed in the design } \\
\text { process as outlined in the SDS. }\end{array}$ \\
\hline 5. & $\begin{array}{l}\text { TFR } \\
\text { Section } 2.2 \\
\text { Stephanie A. }\end{array}$ & Hazardous Classification should be Hazard Classification (10/5/09) & $\begin{array}{l}\text { Text modified to correct } \\
\text { spelling. }\end{array}$ \\
\hline 6. & $\begin{array}{l}\text { TFR } \\
15 / 3.1 .2 .10 \\
\text { Stephanie A. }\end{array}$ & $\begin{array}{l}\text { The basis should be DOE O 420.1B, "Facility Safety." That is the actual driver for fire } \\
\text { protection. Has a preliminary FHA been performed? Your facilities may only need } \\
\text { fre detection due to their small size. This is a big cost driver that can possibly be } \\
\text { avoided. (1/2008) }\end{array}$ & $\begin{array}{l}\text { As discussed in a the CDR, an } \\
\text { FHA will be performed during } \\
\text { the next design phase. Specific } \\
\text { fire detetion/supression system } \\
\text { will be determined at that time. }\end{array}$ \\
\hline 7. & General & Is voice paging required (1/2008) & $\begin{array}{l}\text { Based on the operational plan } \\
\text { where operational personnel } \\
\text { will only be present during } \\
\text { short periods of time and for } \\
\text { limited operations, all } \\
\text { notifications can be } \\
\text { accomplished via handheld } \\
\text { radios. At this point no paging } \\
\text { system is required. }\end{array}$ \\
\hline 8. & $\begin{array}{l}\text { TFR } \\
19 / 3.2 .5 \\
\text { Stephanie A. }\end{array}$ & $\begin{array}{l}\text { What is ther performance category of the facilities for natural phenomena design? } \\
(1 / 2008)\end{array}$ & $\begin{array}{l}\text { PC-1; See section } 2.2 \\
\text { No changes will be made at this } \\
\text { time. Further evaluation will } \\
\text { be performed during the final } \\
\text { design. }\end{array}$ \\
\hline 9. & $\begin{array}{l}\text { TFR } \\
\text { Section } 3.2 .8 \\
\text { Stephanie A. }\end{array}$ & $\begin{array}{l}\text { IBC } 2003 \text { should be IBC } 2009 \text {. I believe that in accordance with DOE } 0430.2 \mathrm{~b} \text {, the } \\
\text { minimum will not only be code (IBC), but the following from DOE O } 430.2 \mathrm{~b} \text { : } \\
\text { "All new buildings will incorporate the Guiding Principles of Executive Order } 13423\end{array}$ & $\begin{array}{l}\text { Reference to IBC was changed } \\
\text { to IBC } 2009 \text {. } \\
\text { Added the requirement to }\end{array}$ \\
\hline
\end{tabular}

QAF-061.2 Rev 4

Effective 03/07/07 


\section{North Wind}

Review Comments and Resolutions

\begin{tabular}{|c|l|l|l|l|}
\hline & & $\begin{array}{l}\text { to the extent practical and life cycle cost effective." Jen Morton can probably provide } \\
\text { the correct language. (10/5/09) }\end{array}$ & $\begin{array}{l}\text { comply with DOE O 430.2B } \\
\text { which in turn will reference the } \\
\text { applicable executive order. }\end{array}$ \\
\hline 10. & $\begin{array}{l}\text { TFR } \\
19 / 3.2 .8 \\
\text { Stephanie A. }\end{array}$ & $\begin{array}{l}\text { Check STD-139 under Energy Conservation. DOE has additional requirements in this } \\
\text { area. (1/2008) }\end{array}$ & See comment \#6 \\
\hline 11. & $\begin{array}{l}\text { TFR } \\
20 / 3.3 \\
\text { Stephanie A. }\end{array}$ & Add a general statement that the facilities must be designed to STD-139 (1/2008) & Comment Accepted \\
\hline
\end{tabular}

${ }^{\star \star}$ If section numbers have been changed, identify the change(s) in the Comment Resolution section of this form. 